National

Academy

of

Sciences

National Research Council

NUCLEAR SCIENCE SERIES

\title{
The Radiochemistry of Barium, Calcium, and Strontium
}




\section{COMMITTEE ON NUCLEAR SCIENCE}

L. F. CURTISS, Chairman

National Bureau of Standards
ROBLEY D. EVANS, Vice Chairman

Massachusetts Institute of Technology

J. A. DeJUREN, Secretary

Westinghouse Electric Corporation

H. J. CURTIS

Brookhaven National Laboratory

SAMUEL EPSTEIN

Callfornla Institute of Technology

HERBERT GOLDSTEIN

Nuclear Development Corporation of America

H. J. GOMBERG

University of Michlgan

E. D. KLEMA

Northwestern University

ROBERT L. PLATZMAN

Argonne National Laboratory
G. G. MANOV

Tracerlab, Inc.

W. WAYNE MEINKE

University of Michigan

A. H. SNELL

Oak Ridge National Laboratory

E. A. UEHLING

University of Washington

D. M. VAN PATTER

Bartol Research Foundation

\section{LIAISON MEMBERS}

PAUL C. AEBERSOLD

Atomic Energy Commission

J. HOW ARD MCMILLEN

National Science Foundation
W. D. URRY

U. S. Air Force

WILLIAM E. WRIGHT

Office of Naval Research

\section{SUBCOMMITTEE ON RADIOCHEMISTRY}

W. WAYNE MEINKE, Chairman

University of Michigan

NATHAN BALLOU

Navy Radiological Defense Laboratory

GREGORY R. CHOPPIN

Florida State University

GEORGE A. COWAN

Los Alamos Sclentific Laboratory

ARTHUR W. FAIRHALL

Untversity of Washington

HARMON FINSTON

Brookhaven National Laboratory
EARL HYDE

University of Californla (Berkeley)

HAROLD KIRBY

Mound Laboratory

GEORGE LEDDICOTTE

Oak Ridge National Laboratory

ELLIS P. STEINBERG

Argonne National Laboratory

PETER C. STEVENSON

University of Callfornia (Livermore)

LEO YAFFE

McGlll University 


\section{DISCLAIMER}

This report was prepared as an account of work sponsored by an agency of the United States Government. Neither the United States Government nor any agency Thereof, nor any of their employees, makes any warranty, express or implied, or assumes any legal liability or responsibility for the accuracy, completeness, or usefulness of any information, apparatus, product, or process disclosed, or represents that its use would not infringe privately owned rights. Reference herein to any specific commercial product, process, or service by trade name, trademark, manufacturer, or otherwise does not necessarily constitute or imply its endorsement, recommendation, or favoring by the United States Government or any agency thereof. The views and opinions of authors expressed herein do not necessarily state or reflect those of the United States Government or any agency thereof. 


\section{DISCLAIMER}

Portions of this document may be illegible in electronic image products. Images are produced from the best available original document. 


\title{
The Radiochemistry of Barium. Calcium, and Strontium
}

\author{
By D. N. SUNDERMAN \\ and \\ C. W. TOWNLEY \\ Battelle Memorial Institute \\ Columbus, Ohio \\ January 1960
}

Subcommittee on Radiochemistry

National Academy of Sciences-National Research Council 
Available as NAS-NS-3010 for $\$ 11.00$ from

National Technical Information Service

U. S. Department of Commerce

Springfield, Virginia 22161

Printed in the United States of America

USDOE Office of Scientific and Technical Information,

Oak Ridge, Tennessee

1960: latest printing May 1985 


\section{FOREWORD}

The subcomittee on ladiochonistry is one of a number of subcomittees working under the Comittee on Nuclear science within the Mational Acadong of Sciences - National Research Council. It: Embers represent govermeont, industriel, and univeratty laboratories in the areas of nuclear chonistry and analytical chenistry.

The Subcomittee has concernod itself with those areas of nuclear acience which involve the chenist, such as the collection and distribution of radiochonical procedures, the extablishent of apecifications for radiochenically pure reagents, the problens of stockplifing uncontaninated naterials, the avallability of cyclotron time for service irradiations, the place of radiochenistry in the undercraduate college progran, etc.

This ser1es of nonographs has grom out of the noed for up-to-date conpilations of radiochonical infornation and procedures. The subcomitteo hes endeavored to present a series which will be of maximun uee to the working acientiot and which contains the latest avedlable information. Each monograph collects in one voluse the pertinent information required for radiochenical work with an Individual elenent or a group of closely related elements.

An expert in the radiochenfstry of the particular element has written the monograph, following a standard fornat developed by the subcomitteo. The Atomic Inergy comlasion has sponeored the printis of the series. 
The subcamittee is confident thece publications will be useful not only to the rediochentst but also to the research worker in other fielde such as physics, blochenistry or sedic1ne who wishes to use radiochenical techniques to solve a apecific problen.

W. Wayne Nolnke, Cha1man Subcomit tee on Radiochenistry 


\section{CONTENTS}

I. General Reviews of the Inorganic and Anelytical Chemistry of Barium, Calcium, and Strontium

II. General Reviews of the Radiochemistry of Barium, Calcium, and Strontium 1

III. Table of Isotopes of Barium, Calcium, and Strontium I

IV. Review of Those Features of Barium, Calcium, and Strontium Chemistry of Chief Interest to Radiochemists

1. Matallic barium, calcium, and strontium 4

2. Soluble salts of berium, calcium, and strontium 4

3. Insoluble salts of barium, calcium, and strontium and precipitation and coprecipitation characteristics of barium, calcium, and strontium.

4. Chelate complexes of barium, calcium, and strontium

5. Extraction of the Thenoyl Trifluoracetone (TTA) Complexes of barium, calcium, and strontium into organic solvents

6. Extraction of barium, calcium, and strontium into organic solvents 15

7. Ion exchange behavior of barium, calcium, and strontium it

v. Dissolution of Materials Containing Brium, Calcium, and Strontium 20

VI. Radioessay Techniques for Barium, Calcium, and Strontium 22

VII. Collection of Detailed Radiocherical Procedures for Barium, Calcium, and Strontium. 


\section{INTRODUCTION}

The. volue which deals with the radiochemistry of barlun, calciu, and etrontiu 1s one of a series of nonographs on radiochemistry of the elemente: There 1s Included a review of the nuclear and chemical features of particular interest to the radiochemst, a discusalon of problen of dissolution of a sample and counting techniques; and I1nally, a collection of radiochenical procedures for the elements as found In the 11 terature.

The werles of wonograph: will cover all elements for wh1ch rad1ochentcal procedures are pertinent. Plana include revision of the monograph perlodicaliy as new tochniques and procedures warrent. The reader 10 therefore encouraged to call to the attention of the author any publianed or unpublizhed neterial on the radiochensetry of bariu, calciu, and strontiw which might be Included in a revised version of the nonograph. 
I. GBNITRAL REVIEWS OF THE INORGANIC AND ANALYTICAL CHEMISTRI OF BARIOM, CULCIUM, 1 DO STRONTIUK

Pp. 259-269 in Vol. I and pp. 244-254 in Vol. II of Annztical Chentstry", F. P. Treadreli, tr. and rev. Wy Wilian T. Ball, John Wiley and Sons, Inc., How Iork, ninth edition, 1937.

Chapter 40, pp. 611-631 in Applied Inorganic Aalraio",

W. F. Hillebrand, G. B. F. Lundell, H. A. Eright, and

J. I. Hoffman, Wileg, Vew Iork, seccond edition, 1953.

Pp. 398-413 in "Prescott and Johnson's Gulitative Chomdcal inalysis", B. X. Hellpine and B. L. Soule, Van Hoatrand, How Ierk, 1933.

Chapter 19, pp. 845-867 in "Inorganic Chomdstry", T. Hoeller, John willey and Sons, Inc., Wew Iork, 1952.

Pp. 117-136, 205-217, and 899-902 in Val. I of "Scott's Standard

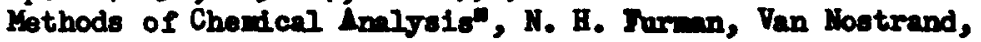
How Iork, 1939.

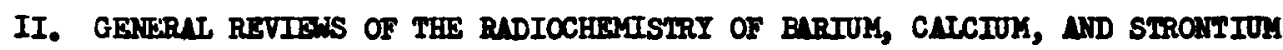

- Evaluation of Radiochenical Separation Procedurec, Dane N. Sundernan and W. Wayno Nainke, Analytical Cbomotry 29, 1578, November 1957.

The Developwent and Eraluation of Radiochentical Separation Procedures for Burium, Calcium, Strontiun, Silvar, and Indiur, Duane N. Sunderman, AECU-3159, Petruary 1956.

III. TAELE OF ISOTOPES OF BARIX, CALCIUM, AND STROMIIX

\begin{tabular}{|c|c|c|c|c|}
\hline \multirow[b]{2}{*}{ Isotope } & \multirow[b]{2}{*}{ Half Life } & \multicolumn{2}{|c|}{ Primry Radiation } & \multirow[b]{2}{*}{ Hothod of Properation } \\
\hline & & 2ype of Decey & torise lare & \\
\hline $\mathrm{Ca}_{2} 38$ & 0.66 sec. & $\beta+$ & $3.5 \mathrm{Kr}$ & \\
\hline 6.39 & $1.0 \mathrm{sec}$ & $\mathrm{A}^{+} 6.1 \mathrm{HT}$ & (nom) & $\mathrm{Cx}^{40}+\mathrm{enam}_{\mathrm{m}}$ \\
\hline$C_{2} 40$ & Stable $-96.97 \%$ & & & \\
\hline$C a^{4 l}$ & $1.1 \times 10^{5} \mathrm{gr}$ & $\mathrm{EC}(100 \%)$ & (none) & Ca40 + noutrons \\
\hline$C_{2} 42$ & Stable $-0.64 \%$ & & & \\
\hline $\mathrm{Ca}_{43}$ & Stable $-0.145 \%$ & & & \\
\hline
\end{tabular}


III. TAES (CONTINUED)

\begin{tabular}{|c|c|c|c|c|}
\hline \multirow[b]{2}{*}{ Isotope } & \multirow[b]{2}{*}{ Half Life } & \multicolumn{2}{|c|}{ Primary Radiations } & \multirow[b]{2}{*}{ Wethod of Preparation } \\
\hline & & Type af Decay & Gamen Hara & \\
\hline $\mathrm{Ca}^{44}$ & Stable $-2.06 \%$ & & & \\
\hline $\mathrm{Ca}^{45}$ & 164 devo & $\beta^{-0.254(100 \%)}$ & (nono) & Cal4 + neutrons \\
\hline $\mathrm{Ca}_{2}{ }^{6}$ & stable -0.00338 & & & \\
\hline$C_{2} 47$ & $4.7 \mathrm{dgys}$ & $\rho^{-1.94}(178)$ & $\begin{array}{l}1.29 \\
0.81\end{array}\left(\begin{array}{l}715) \\
5 \%)\end{array}\right.$ & Ca $46+$ neutrons \\
\hline Ca 48 & Stable $-0.185 \%$ & & $0.50(5 \%)$ & \\
\hline Ca 49 & $8.8 \mathrm{~min}$. & $\begin{array}{l}2.1(89 \%) \\
-1.0(118)\end{array}$ & $\left.\left.\begin{array}{l}3.07 \\
4.04\end{array}\right\} 1098\right)$ & $C_{2} 48+$ neutrons \\
\hline $\operatorname{Sr}^{81}$ & 29 min. & $\beta^{+}$ & & $\mathrm{Bb} 85(p, 5 n)$ \\
\hline$s r^{82}$ & 25.5 degr & $E C$ & & $\mathrm{Bb}^{85}(\mathrm{p}, \mathrm{4n})$ \\
\hline$s r^{83}$ & $34 \mathrm{hrs}$. & $\beta^{+} 1.15$ & $\begin{array}{l}0.040 \\
0.074 \\
0.101 \\
0.151 \\
0.165\end{array}$ & Daughter of Y83 \\
\hline $5 r^{84}$ & Stable $-0.56 \%$ & & & \\
\hline$s r^{85 m}$ & 70 min. & $\min _{E C}\{86 \%\}$ & $\begin{array}{l}0.225(85 \%) \\
0.150(14 \%)\end{array}$ & $\mathrm{Sr}^{84}+$ noutrons \\
\hline$s r^{85}$ & $64 \mathrm{ds}=$ & $\mathrm{BC}(100 \%)$ & $0.513(200 \%)$ & Sx 84 - neutrons \\
\hline$s x^{86}$ & Stable $-9.86 \%$ & & & \\
\hline$s^{87 m}$ & $2.9 \mathrm{hra}$. & Ir $(100 x)$ & 0.388 & $S r^{86}+$ moutrons \\
\hline$s_{x} 87$ & Stable $-7.02 \%$ & & & \\
\hline$s r^{88}$ & Stable $-82.56 \%$ & & & \\
\hline$s r^{89 m}$ & $\sim 10$ deys & II & & \\
\hline$s r^{89}$ & 51 days & $0^{-1.462(99 \%)}$ & $\left.\stackrel{0.913}{(\text { trom }} y_{0.01 \%}^{89 \pi}\right)$ & $\begin{array}{l}\mathrm{Sr}^{88} \text { neutrons, } \\
\text { fiseion product }\end{array}$ \\
\hline$S x^{90}$ & 28 yrs. & $c^{-0.545(1008)}$ & (nono) & Fission product \\
\hline sr91 & 9.7 hrs. & 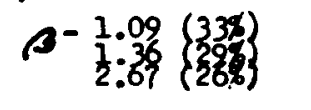 & $\left.\begin{array}{l}0.551 \\
0.575 \\
0.750 \\
1.05\end{array}\right\}$ & $\begin{array}{l}\left.\text { (from } Y^{91 m}\right) \\
\text { Fission product }\end{array}$ \\
\hline $\mathrm{sr}^{92}$ & $2.6 \mathrm{hrs}$. & $s^{-0.55} 1.5(10 \%)$ & o. & Fission product \\
\hline $5 r^{93}$ & 8.2 an. & $\beta^{-}$ & & Fission product \\
\hline $5 \times 94$ & $1.3 \mathrm{~min}$. & $\beta-$ & & Fission product \\
\hline sr 95 & $\sim 0.7 \mathrm{din}$. & & & Fission product \\
\hline $5 r 97$ & Short & $\beta-$ & & Fission product \\
\hline
\end{tabular}


III. TEES (CONTINUED)

\begin{tabular}{|c|c|c|c|c|}
\hline \multirow[b]{2}{*}{ Isotope } & \multirow[b]{2}{*}{ Balf Lifo } & \multicolumn{2}{|c|}{ Primry Radiations } & \multirow[b]{2}{*}{ Hothod of Proparation } \\
\hline & & Trpe or Decay & Gann hays & \\
\hline Bn126 & 97 min. & $\mathbf{E C}$ & $\begin{array}{l}0.23 \\
0.70\end{array}\left(\begin{array}{l}758 \\
258\end{array}\right)$ & \\
\hline $\mathrm{Ba} 127$ & 12 nin. & $\beta^{+}$ & & \\
\hline $\mathbf{B}^{128}$ & $2.4 \mathrm{des} 8$ & $B C$ & 0.270 & $C a^{133}(p, 6 n)$ \\
\hline$B^{129}$ & $2.45 \mathrm{hrs}$ & $\beta^{*} 1.6$ & & $C_{13} 133(p, 5 n)$ \\
\hline Ban 130 & Stable $-0.13 \%$ & & & \\
\hline $\operatorname{Ban}^{131}$ & 11.5 daya & $\mathrm{DC}(100 \%)$ & $\begin{array}{l}0.496 \\
0.122 \\
0 . \frac{214}{312} \\
0.372\end{array}\left\{\begin{array}{l}23 \\
128\end{array}\right\}$ & Bel30 + noutrom \\
\hline $\mathrm{Ba}^{132}$ & Stable $-0.19 \%$ & & & \\
\hline $\mathrm{Ba}^{133}$ & $38.9 \mathrm{hrs}$. & IT $(100 \%)$ & 0.276 & Be132+ noutrons \\
\hline $\begin{array}{l}\operatorname{Ba}^{133} \\
\operatorname{Ban}^{134}\end{array}$ & $\begin{array}{l}7.2 \mathrm{Jrs} \\
\text { Stable }-2.60 \%\end{array}$ & $B C(100 s)$ & $\begin{array}{l}0.357 \\
0.300 \\
0.082\end{array}\left\{\begin{array}{l}69 \% \\
32 \%\end{array}\right\}$ & Bn 232 - noutrons \\
\hline $\mathrm{B}^{135}$ & 28.7 hrs. & IT $(100 \%)$ & 0.268 & Bn$^{134}+$ neatrons \\
\hline En 135 & Stable -6.78 & & & \\
\hline $\operatorname{Bn}^{136}$ & Stable - 8.18 & & & \\
\hline $\operatorname{Ban}^{137 \mathbf{m}}$ & 2.6 min. & Ir (100\%) & 0.662 & $\begin{array}{l}\text { B } 136 \text { - nentrops } \\
\text { daughter of Colst }\end{array}$ \\
\hline $\mathrm{Bd} 137$ & Stable $-11.9 \%$ & & & \\
\hline $\mathrm{Ba} 138$ & Stable $-70.4 \%$ & & & \\
\hline $\mathrm{Be}^{139}$ & 84 min. & 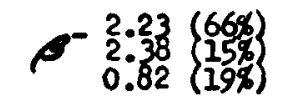 & 0.163 & $\begin{array}{l}\text { Be138 + neutrons, } \\
\text { Ilssion product }\end{array}$ \\
\hline $\mathrm{Be}^{140}$ & 12.80 days & $\beta=\begin{array}{l}-1.0(75 \%) \\
-0.4(25 \%)\end{array}$ & 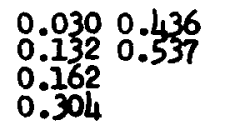 & Fission product \\
\hline $\mathrm{Ba}^{2141}$ & 18 min. & $\beta^{-2.8}$ & & Fission product \\
\hline $\mathrm{Bn}^{142}$ & 6 min. & $\mathrm{C}^{-}$ & & Fission product \\
\hline $\mathrm{Ba}^{243}$ & $<0.5 \min$ & & & Fiesion product \\
\hline $\mathrm{Bn}^{144}$ & Short & $\beta=$ & & Flosion product \\
\hline
\end{tabular}

For more complete information of the radiations of the isotopes of calchn, strontium, and barium and for reforences to the original literature, 800 -Table of Isotopes", D. Stroxinger, J. K. Hollander, and G. T. Saaborg, Haviens of Hodern Physics, 30, No. 2, Part II, April 1958. 
Iv. REVIFW OF THOSE FEATURES OF BARIUM, CALCIUM, AND STRONTIUM CHEMISTRY OF CHIEF INTEREST TO RADIOCHEMISTS

\section{Motallic Barium, Calcium, and Strontium}

Barium, calcium, and strontium are strong reducing agents and are prepared either by electrolytic or thermal means in the absence of moisture. Methods used for this purpose include the electrolysis of the fused chlorides, heating the oxides with aluminum in a vacuum furnace, and electrolysis of an aqueous solution with a mercury cathode with subsequent heating of the mercury amalgram in hydrogen to drive off the mercury.

Barium, calcium, and strontium are very reactive and are readily oxidized in air to the plus two oxidation state. The hydroxides are formed in cold water with an evolution of hydrogen. The metals react vigorously with acids to form the plus two charged cations and evolve hydrogen. The reaction with nitric acid is very rapid, with the formation of nitric oxide. The reaction with dilute sulphuric acid is slow because of the formation of insoluble sulphates.

\section{Soluble Salts of Barium, Calcium, and Strontium}

The soluble salts of barium, calcium, and strontium include the acetates, chlorides, bromides, iodides, nitrates, nitrites, permanganates, sulfides, chlorates, bromates, and perchlorates. Calcium chromate is soluble. The hodroxides of barium, calcium, and strontium are slightly soluble and may be precipitated only from concentrated solutions. The solubilities range from $1.2 \mathrm{~g} /$ liter for $\mathrm{Ca}(\mathrm{OH})_{2}$ to $30 \mathrm{~g} /$ iiter for $\mathrm{Ba}(\mathrm{OH})_{2}$.

3. Insoluble Salts of Barium, Calcium, and StrontiumPrecipitation and Coprecipitation Characteristics of Barium, Calcium, and Strontium

The common insoluble salts of barium, calcium, and strontium are listed in Table 1. A number of these precipitates are suitable for radiochemical separation procedures. The general references listed in Parts I and II describe the insoluble compounds of barium, calcium, and strontium and their use in analyses. The precipitates used most frequently 
in radiochemical and analytical procecures are the chromates, nitrated, oxalates, sulfates, and barium chloride.

Chromate. The chromate precipitation is used in the clasaical seperation of the alkaline earths. Barium chromate is precipitated from a hot solution buffered to a $\mathrm{pH}$ of 4 to 8 . Ammonia is then added to the solution, and the strontium chromate is precipitated. In radiochemical work a pH of 4 is recomended ${ }^{l}$ for the barium precipitation to minimize the strontium and calcium contamination of the barium precipitate.

Nitrate. The Willard and Goodspeed nitric acid mothod ${ }^{2}$ has been frequently used for the separation of barium and strontium from fission products (see Section VII). Fuming nitric acid is added to the solution to yield 60 to 80 per cont $\mathrm{HNO}_{3}$. The barium and strontium nitritos precipitate under these conditions, but calcium nitrate does not. With 70 to 80 per cent HNO $_{3} 100$ per cent yields of barium and strontium have been

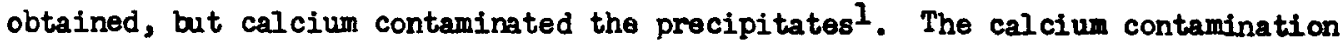
was reduced by using 60 per cent $\mathrm{HNO}_{3}$.

The precipitation of strontium nitrate has been employed as a method of separating 5990 from its 990 daughter ${ }^{3}$. Inactive strontium was added as a carrier, and strontium nitrate was precipitated from a solution of 80 per cent nitric acid, leaving the $Y^{90}$ in solution.

TABLE 1. INSOLUBLE COMPOUNDS OF RARIUR, STRONTIUL, AND CALCIUM

\begin{tabular}{|c|c|c|c|}
\hline Reagent & Precipitate & Solubility in Water & Solubility in Other Roagents \\
\hline \multirow[t]{3}{*}{$F^{-}$} & $\mathrm{BaF}_{2}$ & $\begin{array}{l}\text { slightly soluble } \\
(0.17 \mathrm{~g} / 100 \mathrm{cc})\end{array}$ & soluble in acids and in $\mathrm{NH}_{4} \mathrm{Cl}$ \\
\hline & $\mathrm{SrF}_{2}$ & insoluble & soluble in hot HCI \\
\hline & $\mathrm{CaF}_{2}$ & insoluble & $\begin{array}{l}\text { slightly soluble in acids } \\
\text { soluble in solution of } \mathrm{NH}_{4}^{+} \text {salts }\end{array}$ \\
\hline \multirow[t]{3}{*}{$\mathrm{CO}_{3}=$} & $\mathrm{BaCO}_{3}$ & insoluble & soluble in acids \& in $\mathrm{NH}_{4} \mathrm{Cl}$ \\
\hline & $\mathrm{SrCO}_{3}$ & insoluble & soluble in acids \\
\hline & $\mathrm{CaCO}_{3}$ & insolukle & solukle in acids in $\mathrm{NH}_{4} \mathrm{Cl}$ \\
\hline$c_{2} q_{4}=$ & $\mathrm{BaC}_{2} \mathrm{O}_{4}$ & insoluble & soluble in acids a in $\mathrm{NH}_{4} \mathrm{Cl}$ \\
\hline
\end{tabular}


TLEE 1. (CONTINUED)

\begin{tabular}{|c|c|c|c|}
\hline Reagent & Precipitate & Solubility in Water & Solubility in Otber Reagents \\
\hline \multirow{5}{*}{$\mathrm{sq}_{4}=$} & $\mathrm{SrC}_{2} \mathrm{O}_{4} \cdot \mathrm{H}_{2} \mathrm{O}$ & insoluble & soluble in $\mathrm{HCl}$ and $\mathrm{HNO}_{3}$ \\
\hline & $\mathrm{CaC}_{2} \mathrm{O}_{4} \cdot \mathrm{H}_{2} \mathrm{O}$ & very insoluble & soluble in acids \\
\hline & $\mathrm{BaSO}_{4}$ & very insoluble & slightly soluble in $\mathrm{H}_{2} \mathrm{SO}_{4}$ \\
\hline & $\mathrm{SrSO}_{4}$ & insoluble & $\begin{array}{l}\text { insoluble in alcohol } \\
\text { slightly soluble in acids }\end{array}$ \\
\hline & $\mathrm{CaSq}_{4}$ & slightly soluble & $\begin{array}{l}\text { insoluble in alcohol } \\
\text { soluble in } \mathrm{HCl}\end{array}$ \\
\hline \multirow[t]{2}{*}{$\mathrm{CrO}_{4}=$ or $\mathrm{Cr}_{2} \mathrm{O}_{7}=$} & $\mathrm{EeCrO}_{4}$ & very insoluble & soluble in mineral acido \\
\hline & $\mathrm{SrCrO}_{4}$ & $\begin{array}{l}\text { slightly soluble } \\
(0.11 \mathrm{~g} / 100 \mathrm{cc})\end{array}$ & soluble in acids \\
\hline \multirow{3}{*}{$\begin{array}{l}\text { c. } \mathrm{HCl} \text { and ether } \\
60-80 \% \mathrm{HNO}_{3}\end{array}$} & $\mathrm{BaCl}_{2} \cdot 2 \mathrm{H}_{2} \mathrm{O}$ & soluble & insoluble in c. $\mathrm{HCl}$-ether reagent \\
\hline & $\mathrm{Ba}\left(\mathrm{NO}_{3}\right)_{2}$ & soluble & $\begin{array}{l}\text { insoluble in boiling angl alcohol } \\
\text { insoluble in } 60-80 \% \mathrm{HNO}_{3}\end{array}$ \\
\hline & $\mathrm{Sr}\left(\mathrm{NO}_{3}\right)_{2}$ & soluble & $\begin{array}{l}\text { insoluble in boiling amyl alcohol } \\
\text { insoluble in } 60-80 \% \mathrm{HNO}_{3}\end{array}$ \\
\hline \multirow[t]{3}{*}{$\mathrm{HPQ}_{4}=$} & $\mathrm{BaHPO}_{4}$ & insoluble & soluble in acids \\
\hline & $\mathrm{SrHPQ}_{4}$ & insoluble & soluble in acids \\
\hline & $\mathrm{CaHPQ}{ }_{4} \cdot 2 \mathrm{H}_{2} \mathrm{O}$ & ins aluble & soluble in acids \\
\hline \multirow[t]{3}{*}{$\mathrm{PO}_{4}=$} & $\mathrm{Ba}_{3}\left(\mathrm{PO}_{4}\right)_{2}$ & insoluble & soluble in acids \\
\hline & $\mathrm{Sr}_{3}\left(\mathrm{PO}_{4}\right)_{2}$ & insoluble & soluble in acids \\
\hline & $\mathrm{Ca}_{3}\left(\mathrm{PO}_{4}\right)_{2}$ & insoluble & soluble in acids \\
\hline \multirow[t]{5}{*}{$\mathrm{SO}_{3}=$} & $\mathrm{BaSO}_{3}$ & insoluble & soluble in $\mathrm{HCl}$ \\
\hline & $\mathrm{SrSO}_{3}$ & insoluble & soluble in $\mathrm{ECl}$ \\
\hline & $\mathrm{CaSO}_{3} \cdot 2 \mathrm{H}_{2} \mathrm{O}$ & insoluble & soluble in $\mathrm{ECl}, \mathrm{HnO}_{3}$, and $\mathrm{H}_{2} \mathrm{SO}_{3}$ \\
\hline & $\mathrm{Bn}\left(\mathrm{IO}_{3}\right)_{2} \cdot \mathrm{H}_{2} \mathrm{O}$ & insoluble & soluble in $\mathrm{HCl}$ and $\mathrm{HNO}_{3}$ \\
\hline & $\mathrm{Sr}\left(\mathrm{IO}_{3}\right)_{2}$ & slightly soluble & soluble in boiling water \\
\hline \multirow{4}{*}{$\begin{array}{l}\mathrm{H}_{2} \mathrm{StI}_{6} \\
\text { alcalino } \mathrm{HOO}_{4}=\end{array}$} & $\mathrm{BnSIF}_{6}$ & slightly soluble & insoluble in alcohol \\
\hline & $\mathrm{BnFOO}_{4}$ & insoluble & slightly soluble in acids \\
\hline & $\mathrm{Sr}_{2} \mathrm{HOO}_{4}$ & insoluble & soluble in acids \\
\hline & $\mathrm{CaYHOQ}_{4}$ & insoluble & soluble in acida \\
\hline
\end{tabular}


Chloride. The insolubility of berine chloride in strong bodrochloric

acid solution is a bais for a mothod of soparating barine from calcium, strontiun, and other elements. This mothod has been used in radiocbendical work (see Section VII). The precipitation is performed either by adding an ether-budrochloric acid solution to the aquecus radioisotope salution or by bubbling dry bydrogen chloride gas into an aquecus solution or a mixture of othor and unter. Tho barium chloride precipitate is readily solublo in water, thus facilitating further separations.

Oxalate. The calates of all three alkaline earths are imolubles so the axalate precipitation does not constitute good mothod of decontarinating one alkaline earth fron another. The precipitation of the cxalate from a basic solution with amonium carate is generally used as a convenient ray to reduce an alkaline earth to a weighable and reproductble form sut teble for redioessay.

Salste. The precipitation of bariun sulfate is not genorally used in a separation procedure because of difficulty in performing surther operations on this highly insoluble substance. It is nore wostal as a flinal step in a procedure to secure a form which can be readily dried, weighed, and nounted for counting. Burion is quantitativaly precipttated as the sulfate by slowly adding dilute aulfuric acid to a hot berium solution and digesting the precipitate 4 . For the precipitation of atrontim (or calcium) sulfate, a reagent such as alcohol is required to lowar the solubility, and coagulation mat be accelerated by heat 5 .

Iields of Precipitation Reactions. The jields of calcium, strontiun, and barium in the chromate, nitrate, chloride, oxalate, and sulfate precipitation reactions have been obtained under the conditions described below and the results are sumarized in Table 2. Ten milligrams of carrier of each alkaline earth element and a tracer of the alkaline earth to be determined were used in each field determination.

In the chromate precipitation the excess acid from the carrier and tracer solutions was neutralized with amonium hydroxide, and $10 \mathrm{ml}$ of 
TAEL 2. SUMARY OF YIHE DATA OF PRECIPITATION REACTIONS FOR BARIUM, STRONTIUM, AND CAICIUNO

\begin{tabular}{|c|c|c|c|c|c|}
\hline \multirow{2}{*}{$\begin{array}{l}\text { Precipitating } \\
\text { Solution }\end{array}$} & \multirow[b]{2}{*}{ Condition } & \multicolumn{4}{|c|}{ Per Cent Carried } \\
\hline & & Barium & Strontium & $\mathrm{Ca}$ on $\mathrm{Ba}$ & Ca on Sr \\
\hline \multirow{3}{*}{$\begin{array}{l}\text { Ammontum } \\
\text { Dichromate }\end{array}$} & pH 4 & $70 \pm 3.4$ & $1.6 \pm 0.3$ & $0.8 \pm 0.08$ & \\
\hline & $\mathrm{pH} 5$ & $73 \pm 4.0$ & $8 \pm 0.2$ & $1.1 \pm 0.08$ & \\
\hline & pH 6 & $86 \div 1.3$ & $22 \pm 2.0$ & $1.7 \pm 0.22$ & \\
\hline \multirow[t]{3}{*}{ Nitric Acid } & $80 \%$ & $100 \pm 5.3$ & $100 \pm 1.7$ & $27 \pm 2.2$ & $51 \pm 3.2$ \\
\hline & $70 \%$ & $100 \pm 3.6$ & $98 \pm 1.4$ & $2.4 \pm 0.3$ & $11 \pm 2.3$ \\
\hline & $60 \%$ & $86 \div 3.3$ & $81 \pm 4.2$ & $0.9 \pm 0.05$ & $2.6 \pm 1.0$ \\
\hline \multirow{4}{*}{$\begin{array}{l}\text { Hydrochloric } \\
\text { Acid }\end{array}$} & A. $3 \mathrm{ml} \mathrm{H}_{2} \mathrm{O}$ & $82 \pm 1.1$ & $2.8 \pm 0.9$ & $0.6 \pm 0.4$ & \\
\hline & B. $1.5 \mathrm{ml} \mathrm{H}_{2} \mathrm{O}$ & $92 \pm 2.2$ & $11 \pm 0.7$ & $0.8 \pm 0.08$ & \\
\hline & C. Dry $\mathrm{HCl}$ & $99 \pm 0.4$ & $7.3 \pm 1.6$ & $1.0 \pm 0.1$ & \\
\hline & D. Ether-dry HCl & $93 \pm 2.4$ & $6.0 \pm 3$ & $1.5 \pm 0.1$ & \\
\hline \multirow[t]{2}{*}{$\begin{array}{l}\text { Ammonium } \\
\text { Oxalate }\end{array}$} & $95^{\circ}$ & 59 on $\mathrm{SrC}_{2} \mathrm{O}_{4}$ & 99 & & 1.00 \\
\hline & & 15 on $\mathrm{CaC}_{2} \mathrm{O}_{4}$ & & & \\
\hline Sulfuric Acid & $\begin{array}{l}\text { Excess } \\
\text { Sulfate }\end{array}$ & 100 & $\begin{array}{l}57 \text { on } \mathrm{Ba} \\
\text { Very slight } \\
\text { alone }\end{array}$ & 10 & 3.6 \\
\hline $\begin{array}{l}\text { All values are } \\
\text { The yield data }\end{array}$ & \multicolumn{5}{|c|}{$\begin{array}{l}\text { average of quadruplicate runs. Errors are "standard deviations". } \\
\text { applies only to the experimental conditions described in the text. }\end{array}$} \\
\hline
\end{tabular}

sodium acetate-acetic acid buffer of the desired $\mathrm{pH}(4,5$, or 6$)$ were added. The precipitation was then performed with 2 ml of ammonium dichromate solution $(100 \mathrm{mg} / \mathrm{ml})$. The total volume of solution was $15 \mathrm{ml}$. The nitrate precipitations were performed by adding sufficient fuming nitric acid to secure the desired acid concentration of 60,70 , or 80 per cent. The total volume was 10 to $15 \mathrm{ml}$.

The chloride precipitation was performed by four procedures. In procecture $\triangle$ and $B$ the initial solutions were made up to either 3 or $1.5 \mathrm{ml}$ with water, and the precipitation was done with $10 \mathrm{ml}$ of an HCl-ether 
mixture. The HCl-ethor reagent consisted of 4 parts of LCS reagent grade hydrochloric acid and $I$ part of $\Lambda C S$ reagent grade anhydrous ether. In procecture C, a 10 ml inftial solution was cooled in an ice bath and dry hydrogen chloride was bubbled in until the solution was saturated. In procedure $D$, an initial solution containing 8 ml of water and 3 il of ether was cooled in an ice bath and the dry HCl was bubbled in.

In the cralate precipitations the initial solution was diluted to 8 ml with water and an excess of concentrated ammonium hydroxide was added. One $\mathrm{ml}$ of the hydroxide was usually setisfactory. The eolution was heated to boiling and $2 \mathrm{ml}$ of saturated amonium oxalate solution added with stirring. Again the solution was heated to boiling and allowed to stand for 5 minutes with occasional stirring.

The sulfate precipitation was performed by diluting the inftial solution to $10 \mathrm{ml}$ with $1 \mathrm{M}$ nitric acid and adding $1 \mathrm{ml}$ of $2 \mathrm{M}$ sulfuric acid. Strontium sulfate was found to be more completely precipitated in the presence of barium or cal cium than in their absence.

Contamination of Alkaline Earth Precipitates by Other Activitiea. The contemination of alkaline earth precipitates by other activities was determined by adding $10 \mathrm{ng}$ of carrier and a tracer of the contaminating ion (e.g., $\mathrm{Co}, \mathrm{Ru}, \mathrm{Sb}$, etc.) to a carrier solution containing $10 \mathrm{mg}$ each of the alkaline earths and carrying out the precipitation by the procedures discussed in the preceding section. A sumary of the results is given in Table 3. The yield and decontamination data presented in this table and in Table 2 have been used to develop the optimu alkalim earth procedures given in Section VII (see Procedures 1, 2, and 3).

Ferric Hydroxide as a Carrier for Barium and Strontium. Carrierfroe barium and strontium will coprecipitete with iron precipitated as the hydrated oxide. This is an effective method for remoring trace amounts of barium or strontium from solution. Strontium-85 activity produced by a cyclotron bombardment of a rubidium target has been separated from the large quantity of rubidium by coprecipitation with iron 8 . Lbout 75 per cent of 
TAELE 3. COMTARINUTION OF ALKALINE RARTH PRECIPITATES BY OTHER ACTIVITIES?

\begin{tabular}{|c|c|c|c|c|c|c|c|}
\hline \multirow[b]{2}{*}{ Element } & \multirow{2}{*}{$\begin{array}{c}\text { Chromate } \\
\mathrm{pH}\end{array}$} & \multicolumn{5}{|c|}{$\frac{\text { Precipitating Solution, per cent carried }}{60 \%}$} & \multirow[b]{2}{*}{ Sulfate } \\
\hline & & $\mathrm{HNO}_{3}$ & $\mathrm{HNO}_{3}$ & $\mathrm{HCl}$ & on $\mathrm{SrC}_{2} \mathrm{O}_{4}$ & on $\mathrm{CaC}_{2} \mathrm{O}_{4}$ & \\
\hline Intimong & 55 & 47 & 30 & 28 & 44 & 46 & 28 \\
\hline Barium & 70 & 100 & 86 & 82 & 59 & 15 & 100 \\
\hline Calcium & 0.8 & $\begin{array}{l}51 \text { on } \mathrm{Sr} \\
27 \text { on } \mathrm{Ba}\end{array}$ & $\begin{array}{l}2.6 \text { on } \mathrm{Sr} \\
0.9 \text { on } \mathrm{BR}\end{array}$ & 0.6 & -- & 100 & 10 \\
\hline Cerium & 6 & 3.2 & 2.5 & 0.9 & 98 & 95 & 7.1 \\
\hline Cesium & 3.5 & 1 & 2 & 1 & 0.8 & 1.6 & 2.9 \\
\hline Chromium & 1.2 & 1.8 & 1.0 & 0.7 & 89 & 96 & 0.5 \\
\hline Cobalt & 1.1 & 3 & 3.5 & 1 & 52 & 21 & 0.5 \\
\hline Iodine & 2.0 & 1.2 & 0.8 & 0.9 & 2.3 & 5.0 & 1.5 \\
\hline Iridium & 27 & 4.2 & 0.9 & 5.4 & 47 & 68 & 11 \\
\hline Ruthenium & 5 & 1.5 & 2.4 & 2 & $2 \xi$ & 38 & 0.6 \\
\hline Selenium & 5.7 & 1.4 & 1.3 & 0.9 & 21 & 23 & 1.2 \\
\hline Silver & 89 & 1.9 & 1.5 & 0.8 & 1.2 & 2 & 14 \\
\hline Strontium & 1.6 & 100 & 81 & 2.8 & 99 & -- & 57 \\
\hline Tantelum & 10 & 1 & 0.7 & 0.5 & 49 & 24 & 0.6 \\
\hline Tin & 99.5 & 1 & 1.2 & 0.8 & 73 & 95 & 0.5 \\
\hline Zirconium & 6.3 & 2.6 & 3.3 & 2 & 93 & 88 & 20 \\
\hline & $\begin{array}{l}\mathrm{NO}_{3}^{-} \text {ions } \\
\mathrm{Cl}^{-} \text {ions } \\
\mathrm{F}^{-} \text {ions }\end{array}$ & $\begin{array}{l}\text { prosent in } \\
\text { prosent in } \\
\text { present on }\end{array}$ & $\begin{array}{l}\text { all soluti } \\
\text { all soluti } \\
\text { y in } \mathrm{Ta} \text { so }\end{array}$ & ons e & $\begin{array}{l}\text { cept with } \\
\text { and possi }\end{array}$ & {$\left[, \mathbf{A g}_{\mathbf{B}}\right.$, and } & \\
\hline
\end{tabular}

The data above applies only to the experimental conditions described in the text. 
the strontium is precipitated with the ferric hodroxide, leaving the rebiat in in solution. The iron is removed from the strontiun by etbar-axtraction.

The optimen conditions for coprecipitation of barium with ferric hydrcuide have been investigated, and the amount of barine carried has been found to increase with the amount of iron precipitated, the time of settling, and the pH of the supernte. At a pH of 8, approximately 90 per cent of the bariun is carried. Similar studies with strontium have shown that approximately 50 per cent of the strontinm coprecipitates with the ferric hydroxide at a $\mathrm{pH}$ of $8^{10}$. Calcium has been found to not coprecipitate with ferric hydroxidell.

\section{Lead Sul fate as a Carrier for Barium and Strontine. The co-} precipitation of berium and strontium on $\mathrm{PbSO}_{4}$ can be used to separate carrier-free quantities of these elements from fission products ${ }^{12}$. The $\mathrm{PbSO}_{4}$ 1s precipitated with $\mathrm{PO}\left(\mathrm{NO}_{3}\right)_{2}$ and sulfuric acid. About 90 to 95 per cent of the barium and 80 per cent of the strontium are coprecipitated. Small anounts of othor elements such as cerium, uranium, and thorium are also precipitated. Host of the lead can be removed by converting the sulfate to carbonate, dissolving it in hot ECI, and precipitating the chloride. The lead not removed by this procedure can be precipitated as the sulfide, or it might be removed by selective elution from an EDTA-loaded Dowex-1 ion exchange resin 13 .

Lead chromate can be used as a carrier for bariun to separate trace quantities of barium from tracer strontium, and lead nitrate can be used as a carrier for both barium and strontium ${ }^{14}$.

\section{Chelate Complexes of Barium, Calcium, and Strontium} Chelate complexes of barium, calcium, and strontium have not been applied to radiochemical procedures to ang great extent. It is wortminile, however, to consider some of the complexes formed in order to understand wat effect various chelating agents have on a solution of alkaline earth ions. .

A sumary of som of the chelating agents forming complexes with the alkaline earths is given in Table 4. The formation constants of the $1: 1$ 
TABLE 4. BARTOM, GALCIJM, AND STRONTIUM COMPLEXES OF SOME COMPLEXING IGENTS

\begin{tabular}{|c|c|c|c|c|}
\hline $\begin{array}{c}\text { Chelating } \\
\text { Agent }\end{array}$ & $\begin{array}{c}\text { Mkaline } \\
\text { Earth }\end{array}$ & $\log K$ & $\begin{array}{c}\text { Ionic } \\
\text { Strength }\end{array}$ & Reference \\
\hline \multirow[t]{3}{*}{ EDT } & $\mathrm{Ba}$ & 7.76 & 0.1 & a \\
\hline & $\mathrm{Ca}$ & 10.59 & 0.1 & $\mathbf{a}$ \\
\hline & $\mathbf{S r}$ & 8.63 & 0.1 & 8 \\
\hline \multirow[t]{3}{*}{ Oxalic acid } & $\mathrm{Ba}$ & 2.31 & 0 & b \\
\hline & $\mathrm{Ca}$ & 3.00 & 0 & b \\
\hline & $\mathrm{Sr}$ & 2.54 & 0 & b \\
\hline \multirow[t]{5}{*}{ Malonic acid } & $\mathrm{Ba}$ & 1.23 & 0.2 & c \\
\hline & & 1.71 & 0.04 & $d$ \\
\hline & $\mathrm{Ca}$ & 1.46 & 0.2 & c \\
\hline & & 2.49 & 0.04 & $d$ \\
\hline & $\mathbf{S r}$ & 1.25 & 0.2 & c \\
\hline \multirow[t]{3}{*}{ Succinic acid } & $\mathrm{BQ}$ & 0.97 & 0.15 & e \\
\hline & $\mathrm{Ca}$ & 1.16 & 0.15 & e \\
\hline & $\mathrm{Sr}$ & 0.75 & 0.16 & 1 \\
\hline \multirow[t]{2}{*}{ Maleic acid } & $\mathrm{Ca}$ & 1.2 & 0.16 & $\mathbf{f}$ \\
\hline & $\mathbf{S r}$ & 1.1 & 0.16 & $f$ \\
\hline \multirow[t]{2}{*}{ Citraconic acid } & $\mathbf{C a}$ & 1.3 & 0.16 & $\mathbf{f}$ \\
\hline & $\mathrm{Sr}$ & 1.3 & 0.16 & $f$ \\
\hline \multirow[t]{3}{*}{ Citric acid } & $\mathrm{Ba}$ & 2.3 & 0.16 & $\mathbf{g}$ \\
\hline & $\mathrm{Ca}$ & 3.4 & 0.16 & $\mathbf{f}$ \\
\hline & $\mathbf{S r}$ & 2.7 & 0.16 & $\mathbf{g}$ \\
\hline \multirow[t]{3}{*}{ Tartaric acid } & $\mathrm{Be}$ & 1.62 & 0.2 & c \\
\hline & $\mathrm{Ca}$ & 1.80 & 0.2 & c \\
\hline & $\mathrm{Sr}$ & 1.65 & 0.2 & c \\
\hline \multirow[t]{2}{*}{ Trimetaphosphoric acid } & $\mathbf{H a}$ & 3.35 & 0 & $\mathbf{h}$ \\
\hline & $\mathbf{C a}$ & 3.45 & 0 & $\mathbf{h}$ \\
\hline O-phthal ic acid & $\mathrm{Ba}$ & 0.92 & 0.15 & $\theta$ \\
\hline Anmoniatriacetic acid & $\mathrm{Ba}$ & 6.41 & 0 & $\mathbf{i}$ \\
\hline
\end{tabular}


TABIE 4. (CONT'D)

\begin{tabular}{|c|c|c|c|c|}
\hline $\begin{array}{c}\text { Chelating } \\
\text { igent }\end{array}$ & $\begin{array}{c}\text { Mlkaline } \\
\text { Earth }\end{array}$ & $\log K$ & $\begin{array}{c}\text { Ionic } \\
\text { Strength }\end{array}$ & Reference \\
\hline \multirow[t]{4}{*}{ Inmoniatriacetic acid } & $\mathrm{Ca}$ & 6.41 & 0.1 & $\mathfrak{j}$ \\
\hline & & 8.18 & 0 & 1 \\
\hline & sr & 4.98 & 0.1 & J \\
\hline & & 6.73 & 0 & $i$ \\
\hline \multirow[t]{3}{*}{ Lactic acid } & $\mathrm{Ba}$ & 0.55 & 0.2 & c \\
\hline & $\mathrm{Ca}$ & 1.07 & 0.2 & c \\
\hline & sr & 0.70 & 0.2 & c \\
\hline \multirow[t]{3}{*}{ Malic acid } & Be & 1.30 & 0.2 & c \\
\hline & $\mathrm{Ca}$ & 1.80 & 0.2 & c \\
\hline & Sr & 1.45 & 0.2 & c \\
\hline \multirow{3}{*}{$\begin{array}{l}\text { Wothylamine-N, N,- } \\
\text { diacetic acid }\end{array}$} & Be & 2.59 & 0.1 & $\mathfrak{j}$ \\
\hline & Ca & 3.75 & 0.1 & $\mathbf{j}$ \\
\hline & Sr & 2.85 & 0.1 & $\mathbf{j}$ \\
\hline \multirow[t]{2}{*}{8 -Ouinolinol } & $\mathbf{S r}$ & 2.39 & 0.1 & $\mathbf{k}$ \\
\hline & & $0.84\left(\log K_{2}\right) *$ & 0.1 & $\mathbf{k}$ \\
\hline
\end{tabular}

* Formation constant for Sr/2.

a. G. Schwarzenbach and H. Ackerman, Helv. Chim. Acta 31, 1029 (1948).

b. R. W. Money and C. h. Davies, Trans. Faraday Soc. 28, 609 (1932).

c. R. K. Camnan and A. Kibrick, J. Am. Chom. Soc. 60, 2314 (1938).

d. D. I. Stock and C. W. Davies, J. Chem. Soc. 1949, 1371.

e. N. R. Joseph, J. Biol. Chem. 164, 529 (1946).

f. 1. E. Martell and M. Calvin, MChemistry of the Metal Chelate Compounds", Prentice-Hall, Inc., New York (1952).

g. J. Schubert and J. Richter, J. Am. Chom. Soc. 70, 4259 (1948).

h. H. W. Jones, C. B. Monk, and C. W. Davies, J. Chem. Soc. 1949, 2693.

i. G. Schwarzenbach, E. Kampitisch, and R. Steiner, Holv. Chim. Acte 28, 828 (1945).

j. G. Schwarzenbach, H. Lckerman, and P. Buckstuhl, Helv. Chim, Lcte 32, 1175 (1949).

k. D. Dyrssen, Svensk Kom. Tidskr 67, 317 (1955). 
chelates are also given, and they show that the stability of the complexes formed with a particular chelating agent decreases with increasing atomic weight. Calcium forms the most steble complexes and barium, the least stable.

The ethylene diemine tetra-ecetic acid (EDTA) complex of calcium has been used in an analytical procedure ${ }^{15}$. The calcium is titrated with EDTA, using "arsenazo" as an indicator. The indicator changes from violet to orange at the end point. The formation of the barium EDTA complex may be used to dissolve barium sulfate16. This procedure can be employed in the course of a separation to assist in decontamination of a barium sulfate precipitate. The precipitate is dissolved in a hot amoniacal solution of EDTA and reprecipitated by dilution and acidification. Sodium rhodizonate forms chelate complexes with barium and strontium that are used as spot tests for these ions 17 . Insoluble chelate complexes of barium, calcium, and strontium are formed with picrolonic acid ${ }^{18}$. These chelates are soluble in acetic acid. Complexing agents such as EDTA, citric acid, and lactic acid are used in ion exchange procedures for the alkaline earths.

\section{Extraction of the Thenoyl Trifluoroacetone (TTA) Complexes} of Barium, Calcium, and Strontium Into Organic Solvents. I thenoyl trifluoroacetone extraction has been used for the purification of carrier-free $\mathrm{C}_{2} 45$ produced in the neutron bombardment of scandium ${ }^{19}$. The scandium is removed by solvent extraction at $\mathrm{pH} 5$ into a $0.5 \mathrm{M}$ solution of TTA in benzene, and the calcium is extracted by a $0.5 \mathrm{M}$ solution of TTA in benzene at $\mathrm{pH} 8.2$. The calcium is removed from the benzene phase by back-extraction with water or dilute acid. The equilibrium constant for the calcium extraction at $25 \mathrm{C}$ is:

$$
K_{C_{2}}=\frac{\left(\mathrm{CaT}_{2}\right)_{\mathrm{B}}\left(\mathrm{H}^{+}\right)^{2}}{\left(\mathrm{Ca}^{+2}\right)_{\mathrm{A}}(\mathrm{HT})_{\mathrm{B}}^{2}}=1 \times 10^{-12}
$$

where $B$ and $\perp$ represent the benzene and aqueous phases, respectively 20 . More than 99 per cent of the calcium is extracted at $\mathrm{pH} 8.2$. 
Strontium has been extracted at a pH greater than 10 into a $0.02 \mathrm{H}$ solution of TTA in benzene21. The equilibrium constant for this extraction is $7.5 \times 10^{-15}$. A TTL extraction at $\mathrm{pH} 5$ has been used to separate $\mathrm{Y}^{90}$ from Sr90. 22, 23, 24 Yttrium extracts into a benzene solution of TIA at this $\mathrm{pH}$, but strontium does not. Kiba and Kieukami ${ }^{25}$ report the extraction of strontium at pH 8 into a 0,05 M solution of TTA in haxane.

No information has been located on the extraction of a TT complex of barium into an organic solvent, but considering the pH values required to extract calcium and strontium into a benzene solution of TTA, a pH of greater than 10 or 11 would probably be required for the extraction of barium into this solvent.

\section{Extraction of Barium, Calcium, and Strontium Into Organic}

Solvents. Applications of solvent extraction to the radiochemical analysis of barium, calcium, and strontium are not extensive. Morrison and Freiser ${ }^{26}$ have reviewed extraction procedures, and some of the solvents they mention for the alkaline earths are discussed below. Fen procedures are specific for barium, calcium, and strontium, and the applications have mainly been to the separation of the alkaline earths from one another.

Alcohol and Ether - 1:1 mixture of absolute alcohol and absolute ether has been used to extract anhydrous calcium nitrate from strontium and barium 27 . A solution of the alkaline earths is evaporated to dryness in the presence of nitric acid, and the calcium nitrate is extracted from the dry ass by washing with the alcohol ther mixture. The solubility of the calcium nitrate in the alcohol-ether udxture is 0.37 grams of $\mathrm{Ca}\left(\mathrm{NO}_{3}\right)_{2}$ per ml.

Butyl Cellosolve - Anhydrous calcium nitrate can be separated from strontium and barium in the same manner as discussed above with alcohol and ether, using the monobutyl ether of ethylene glycol (butyl cellosolve) ${ }^{28}$. The hydrated nitrates and the butyl cellosolve are rendered anhydrous by boiling the nitrates in the reagent. The solubility of anhydrous calcium nitrate in butyl cellosolve is $0.243 \mathrm{~g} / \mathrm{ml}$. The solubilities of the barium 
and strontium nitrates in the solvent are not more than $2.3 \times 10^{-6}$ and $1.1 \times 10^{-5} \mathrm{~g} / \mathrm{ml}$, respectively.

Acetone - The anhydrous calcium nitrate can also be extracted into acetone to the extent of $0.212 \mathrm{~g} / \mathrm{ml}^{29}$.

8-Quinolinol in Chloroform - Strontium can be extracted into a $1 \mathrm{~W}$ solution of 8-quinolinol in chloroform 30 . An aqueous solution of less than $0.1 \mathrm{mg}$ of strontium is brought to $2 \mathrm{pH}$ of 11.3 with sodium hydroxide and diluted to $15 \mathrm{ml}$. This is shaken with the organic solvent, and approximately 96 per cent of the strontium will be extracted.

13 per cent 8-quinolinol solution in chloroform can be used to extract calcium from a solution at a pH of 13 containing butyl cellosolve and up to 80 micrograms of calcium ${ }^{31}$.

Di (2-ethyl hexyl) Orthophosphoric 1c1d in Toluene - $1.5 \mathrm{M}$ solution of di (2-ethyl hexyl) crthophosphoric acid (EDEHP) in toluene has been used to separate $\mathrm{Y}^{90}$ from $\mathrm{Sr}^{90}$, and $\mathrm{La}^{140}$ from Ba ${ }^{140}, 32$ The $\mathrm{Y}^{90}$ is extracted by this reagent from $20.1 \mathrm{M} \mathrm{HCl}$ solution leaving most of the strontium in the aqueous phase. The distribution ratio (K), i.e., the ratio of the concentration of a specific nuclide in the organic phase to the concentration of that nuclide in the organic phase to the concentration of that nuclide in the aqueous phase, for strontium in this system is $1.6 \times 10^{-2}$ and that for yttrium is greater than $10^{4}$.

$\mathrm{Ia}^{140}$ is separated from $\mathrm{Ba}^{140}$ by extracting the lanthanum from a $0.05 \mathrm{M}$ HCl solution. The $\mathrm{K}$ value for the barium is $3 \times 10^{-2}$, and that for lanthanum is 50. A detailed study of the extraction of strontium and barium by KDEHP in toluene has not been made, but the distribution ratios are known to be approximately inversely proportional to the second power of the aqueous acid concentration and directly proportional to the second power of the HDEHP concentration 32 .

7. Ion Exchange Behavior of Barium, Calctum, and Strontium. TIme considerations have thus far prevented the general applicability of ion exchange procedures to raptd radiochemical separations of the 
alkaline earths. Good separations have been obtained, but most procectures require stx hours or more. Ion exchange is very good, however, for trace quantities of barium, calcium, and strontium; and this method has been applied to the separation of alkaline earths from fission products, from products of neutron irradiations, and from each other.

Cation Bxchange. A cation exchange resin such as Dowex-50 wtll adsorb ions of the same valence in the order of their increasing hydrated Ionic radil, the smaller hydrated lons being adsorbed first. Bonner and Sinith 33 itst a selectively scale for divalent 1ons or Dowex-50, and fram this scale one can determitine that the sequence of adsorption of the alkaline earths will be $\mathrm{Ba}^{++}$first, then $\mathrm{Sr}^{++}$, and then $\mathrm{Ca}^{++}$. When the alkaline earths are eluted from a resin with a complexing agent, the order of elution depends upon the relative stabilities of the metal complexes formed. The alkaline earth forming the most stable complex will be eluted first, and normally this will be calcium.

Carrier-free strontium and barium have been seperated from fission products on a column of Amberlite IR-I (40-60 mosh) $)^{34}$. Zirconiom and niobium were removed first with 0.5 per cent oxalic acid, and gttrium, cerium, and the rare earths were eluted next with 5 per cent citric acid adjusted to a $\mathrm{pH}$ of 3 with $\mathrm{NH}_{4} \mathrm{OH}$. The strontium and barium were removed with an eluant of 5 per cent citric acid at a $\mathrm{pH}$ of 5 . The strontium came off the colum first.

Tompkins ${ }^{35}$ separated radioactive strontium, barium, and radium on a $1 \mathrm{~cm}^{2} \times 15 \mathrm{~cm}$ column of colloidal agglomerates of Dowex-50. The initial solution contained $20 \mathrm{mg}$ of strontium, $20 \mathrm{mg}$ of barium, and $20 \mu \mathrm{g}$ of radium. The elution was carried out with $0.5 \mathrm{M}$ ammonium citrate at a $\mathrm{pH}$ of 7.8 and with a flow rate of $0.3 \mathrm{ml}$ per minute. All of the strontium was in the first $4 \mathrm{ml}$ of eluate, all of the barium was in the next $4 \mathrm{ml}$, and the radium was in the last 8 to $10 \mathrm{ml}$. W. H. Power, et al., separated barium and radium on a Dowrex-50 column by adding the barium and radium to the column In a solution of $0.2 \mathrm{~N}$ nttric or hydrochloric actd and eluting with $0.32 \mathrm{M}$ 
ammontum citrate at $\mathrm{pH} 5.6^{36}$. The barium was eluted first, Barium to radium ratios as high as 4440 to 1 were separated with one elution. Strontium-90 has been separated from its $\mathrm{Y}^{90}$ daughter by ion exchange with Dowex-5037.38. The $\mathrm{Sr}^{90}-\mathrm{Y}^{90}$ solution is added to the column after the resin has been converted to the ammonium form with ammonium citrate at $\mathrm{pH} 6$. The yttrium is eluted with a 5 per cent solution of amonium citrate at $\mathrm{pH}$ 3.8. The strontium is eluted with ammonium citrate at $\mathrm{pH}$ 6.0. Barium-140 has been separated from its Lo $^{140}$ daughter in the same manner ${ }^{39}$. The $\mathrm{I}^{140}$ is eluted from a Dowex-50 column with citric acid at $\mathrm{pH} 3.8$, and the $\mathrm{Ba}^{140}$ is eluted with the same reagent at pH 6.0.

An Ion exchange separation with Dowex -50 has been employed in the radiochemical analysis of strontium and barium in urine 40 . The EDTA chelates of the alkaline earths in urine at a pH of 5.5 are passed through the column. Calcium and magnesium are eluted with a solution of citric acid and EDTs at $\mathrm{pH} 5$, and sodium is eluted with $0.5 \mathrm{~N}$ hydrochloric acid. The strontium and barium are then removed from the colum with $6 \mathrm{~N}$ nitric acid.

Milton and Grummitt 4 ll studied the cation-exchange separation of the alkaline earths with $21.1 \times 8 \mathrm{~cm}$. Dowex-50 colum at elevated temperatures and applied this to the analysis of $\mathrm{Sr}^{90}$ in milk ash samples. They eluted gnesium, calcium, strontium, barium, and radium in that order with $1.5 \mathrm{M}$ ammonium lactate at pH 7 and at 78 degrees Centigrade. They also obtained good separations with $1.5 \mathrm{M}$ and $4 \mathrm{M}$ hydrochloric acid eluants and with an eluant of 5 per cent amnonium citrate at pH 5 . Temperatures of 60 degrees and 78 degrees Centigrade were used for the hydrochloric acid and ammonium citrate elutions, respectively.

Strontium and calcium have been separated on a Zeokarb 225 column in the sodium form ${ }^{42}$. The strontium and calcium in an EDT solution at pH 5.25 are added to the colum. The strontium is retained on the resin and 
the calcium-EDTN complex passes through. The strontium is then eluted with $3 \mathrm{~N}$ hydrochloric acid.

Calcium has been separated by ion exchange from tracer scandiun and the radicactive impurities produced in it by neutron irradiation 43 . The calcium is adsorbed on a $4.5 \mathrm{~cm}$ colum containing $0.25 \mathrm{~g}$ of 50 micron perticle size zeokarb 225 and eluted with hydrochloric acid.

The alkaline earths have been quantitatively separated from each other in millimole quantities on a colum of Dowex-50 (120 mssh) 4h. The colum size was $2.5 \mathrm{~cm}^{2} \times 19 \mathrm{~cm}$, and the eluant was $1.20 \mathrm{~N}$ ammonium lactate at a flow rate of $1.4 \mathrm{ml}$ per minute. The first $74 \mathrm{ml}$ contained all of the calcium, the next $58 \mathrm{ml}$ contained all of the strontium, and the barium was in the last $325 \mathrm{ml}$. The separation required 6 hours. Anion Exchange. I few procedures utilizing anion exchange columns have been reported for the alkaline earths. Strontium-90 has been separated from $Y^{90}$ on a Dowex-1 colum pretreated with wydroxide 45 . The strontium is eluted from the column with water, and the yttrium remains on the colum as $\mathrm{Y}(\mathrm{OH})_{3}$. The yttrium may be eluted with 1 hydrochloric acid. Inother strontium and Jttrium separation has been reported, using a nitrate losded Dowex-l colum containing som 8-hydroxyquinoline -5-sulfonic acid (HCS) 46 . The strontium is eluted from the colum first with a solution 0.1 molar in $\mathrm{NaNO}_{3}$ and 0.0005 molar in HCS at a pH of 5.5 .

Barium-140 has been separated from Ial40 on an hydroxide charged Dowex-1 column 47. $0.01 \mathrm{~N}$ hydrochloric acid solution of the barium and lanthanum is passed through the colum, and the effluent contains radiochemically pure Bllio. Any barium remaining on the colum mey be eluted with water. The $\mathrm{La}^{1 / 40}$ stays on the colum and be eluted with dilute nitric acid.

The alkaline earths have been separated from each other on a citrate resin pretreated with $0.05 \mathrm{M}$ ammonium citrate at $\mathrm{pH} 7.5^{48}$. chloride solution of the alkaline earths was added to the colum, and the 
elution was performed with $0.05 \mathrm{M}$ ammonium citrate at $\mathrm{pH} 7.5$. The barium was eluted first, followed by the strontium and then the calcium.

James and Welch 49 report the adsorption of trace amounts of strontium on an Amberlite IR -400 resin by the formation of an insoluble salt. Trace amounts of strontium were adsorbed on the resin in the oxalate form (the solubility of strontium oxalate is $0.05 \mathrm{~g} / 1$ ). The strontium was readily eluted with dilute acid. With a chromate resin form only abcut 80 per cent of the strontium was adsorbed, and with an hydraxide resin form the strontium was not adsorbed. Strontium chromate has a solubility of $1.5 \mathrm{~g} / \mathrm{l}$, and strontium hydroxide, $17.4 \mathrm{~g} / 1$. The limit of solubility for the application of this technique appears to be approximately $1.5 \mathrm{~g} / 1$.

The fact that strontium is not adsorbed on an Amberlite IRA-400 colum in the bydroxide form has been employed to separate strontium and cesium from fission products 50 . N1 of the fission products present in their solutions except strontium and cesium are removed from solution by this colum (assuming barium is absent).

\section{DISSOLUTION OF MATERIAL CONTAINDTG BARIUN, CALCIUM, AND STRONTIUM}

The problem of dissolving a sample for the subsequent radiochemical analysis of the alkaline earths is in most cases a simple one. Water can be used to dissolve such compounds as the acetates, bromides, chlorides, chlorates, perchlorates, cyanides, ferricyanides, iodides, nitrates, nitrites, and permanganates. Hydrochloric or nitric acid dissolves the fluorides, carbonates, oxalates, chromates, phosphates, sulfates (except barium), and oxides.

Barium sulfate can be dissolved by treatment with hot, concentrated surfuric acid, but dilution with water causes reprecipitation of the sulfate. To obtain a solution of barium ions from barium sulfe, it is best to convert the sulfate to barium carbonate by fusion with sodium carbonate 51 . The sulfate is mixed with four to six times as mach anhydrous sodium carbonate and fused in a platimm crucible. The residue is cooled, boiled in a little water, filtered, and washed with hot sodium carbonate solution to remove 
the sulfate ions. The barium carbonate residue is then dissolved in dilute hydrochloric or nitric acid.

Frequently barium-, calcium-, or strontium-containing torials such as limestone, cement, soil, bones, and biological materials must be brought into solution. Hot hydrochloric acid can be used to dissolve limestone and cemont. An insoluble residue of silica will romin, and this can be filtered or centrifuged.

In removing alkaline earthe from soil it mey not be necessary to bring the soil into solution. Strontium, for example, has been leached from soil with acid 52 . Twenty-five milliliters of IX nitric acid is added to ten grams of soil and stirred to suspend the soll. This is heated and stirred for three to four minutes and centrifuged. Kahn 53 reports that $86.2 \pm 1.1$ per cent of the strontium is removed per leach and 99.5 per cent is removed in three leaches. To separate the strontiun from calciun dissolved by the acid, add strontium carrier and precipitate the albaline earth carbonates from basic solution; redissolve the carbonates in nitric acid and precipitate strontium nitrete with fuming nitric acid, leaving the calcium in solution.

In ammonium acetate leach can also be exployed to extract calcium and strontium from soil 54 . The soil is crushed and suspended overnight in a normal solution of ammonium acetate at pH 7. The suspension is filtered, and the filtrate is evaporated to dryness and abed at 600 degrees Centigrade. The sshed residue is dissolved in hydrochloric acid, and iron and aluminum are removed a horoxide precipitation. Calcium and strontium are then precipitated as the coalate,

In some cases the leaching procedure may not work and the soil must be dissolved by an alkali fusion 55 . The soil is ground to a powder in a mortar and pestle and added to a fusion mixture of 2,1 :l by weight of potassium hydroxide, nitrate, and carbonate. The fusion mature ahould be five to ten times the weight of the soil sample. The fusion wixture is heated for two hours at 550 degrees Centigrade, while swirling the contents 
at fifteen minute intervals. The mifture is then cooled and leached with $10 \mathrm{ml}$ of water. The alkaline earths remain in the molt. Ten ml of $6 \mathrm{~N}$ nitric acid is added and the mixture is heated. This is taken to dryness twice with addition of conc. nitric acid to dehodrate the silica. The melt is redissolved in nitric or hydrochloric acid, and the silica is centrifuged.

Biological samples such as plant material or dairy products are first ashed by heating at $600 \mathrm{C}$ for several hours 54 . Wilk samples are first ovaporated to dryness and then ashod. The milk ash goes readily into solution in hot, concentrated hydrochloric acid, but in the case of the plant ash it is necessary to perform two extractions with aqua regia 54. In some cases one prefer to wet ash biological material by treatment with nitric acid followed by an equal volume mixture of nitric and perchloric acids 56 .

Human and animal bone samples are first ashed for about 4 hours at $900 \mathrm{C}$ and then dissolved in hot, concentrated hydrochloric acid 54.

\section{RADIOASSAY TECHIIUES FOR BARIUM, CALCIUM, AND STRONTIUM}

In the radioassay of solutions or precipltates containing radioisotopes of barium, calcium, or strontium particular attention must be paid to the decay 8 chemes and radiations of these isotopes. Such factors as half life, type of radiation, and energy of radiation mast be considered. Nuclear characteristics of the isotopes of the alkaline earths can be found in the literature 57 and are summarized in Section III.

Calcium- 45 is the radioisotope commonly used as a tracer in calcium analysis. This isotope emits beta particles with a maximum energy of $0.254 \mathrm{Mev}$, and it emits no gamm radiation. I thin-window Geiger or proportionel counter is useful for radioassay of $\mathrm{Ca}^{45}$. In neutron activations of calcium $\mathrm{Ca}^{41}, \mathrm{Ca}^{47}$, and $\mathrm{Ca}^{49}$ may be produced in addition to $\mathrm{Ca}^{45}$. Iong-lived Call emits no radiation other than 0.003 Mev I-rays which are difficult to measure. These low energy $X$-rays may be counted in a proportional counter with a thin window. The 8.8 minute $\mathrm{Ca}^{49}$ will not be 
encountered unless work is begun very soon after lrradiation, in which case It is best determined by counting the 1.0 and 2.1 bev bete particles with a Geiger or proportional counter. The 4.7 das Ca 47 emits 0.66 and $1.94 \mathrm{Mav}$ beta particles in addition to gama rays at $0.50,0.81$, and 1.29 mev. The beta particles can be detected with a Geiger or proportional counter, and the gamme radiation can be determined with a scintillation detector. Decay corrections must be made in counting $\mathrm{Ca}_{2}^{49}$, and they should be made for $\mathrm{Ca}_{2} 7$ if the counting extends over a period of a few hours.

If $\mathrm{C}_{2} 45, \mathrm{C}_{2} 47$, and $\mathrm{C}_{2} 49$ are present in an activated sample, they will all contribute to the beta count and a decay curve must be determined and resolved to obtain the quantity of each isotope. If only 164 day $\mathrm{Ca}^{45}$ is to be counted, the chemical separation of calcium should be carried out after the decay of the short-lived 1sotopes.

Strontium-89 and strontium-90 are comonly used as tracers for strontium analysis and are often determined in fission product and fall-out studies. both are beta-emittere and can be determined with a Geiger or proportional counter. $\mathrm{Sr}^{89}$ is always determined by bete-counting the strontium precipitate. $5 r^{90}$ decays to $6 I$ hour $Y^{90}$ which is also a beta-emitter. When activities from daughter products interfere in counting, three methods of measurement are possible. In one, a tim lapse of about 10 half lives is allowed between the strontium separation and the counting to permit the mixture to reach radiaactive equilibrium, when the ratio of parent-to-daughter activity is constant. In the second method, the $\mathrm{Y}^{90}$ is removed by precipitating it as the hydroxide 58 , extracting it from an acetate buffered solution at $\mathrm{pH} 5$ into a 5 per cent solution of TTA in benzene 59 , or selectively eluting the yttrium from an ion exchange col umm 60,61 . The $\mathrm{Sr}^{90}$ is then separated and radiossseged before the $\mathrm{Y}^{90}$ again becomes measurable.

The third mothod, which is most commonly used, also involves a separation of the $\mathrm{Sr}^{90}$ and $\mathrm{Y} 90$. After the complete chemical procedure is performed to separate the strontium from the fission product or fall-out 
sample, the strontium is atored for a period of time to permit ingrowth of $\mathrm{r}^{90}$. The $\mathrm{Y}^{90}$ is then milked from the strontium by one of the methods described above and bota-assayed. The $\mathrm{sr} 90$ disintegration rate, $\mathrm{I}_{\mathrm{Sr}} 90$, of the original sample is calculated by means of the equation 60 ?

$$
I_{S r 90}=\frac{I_{Y 90}}{Y_{S Y} \cdot Y_{Y}\left(1-e^{-t / 93}\right)}
$$

where $Y_{S r}$ and $Y_{Y}$ are the chemical gields for the strontium separation and the gttrium milking. The factor $1 /\left(1-e^{-t / 93}\right)$ is the correction factor for $Y^{90}$ growth when the ingrowth timo is $t$ hours. I I 90 is the disintegration rate of the $\mathrm{Y}^{90}$ milked from the strontium. The 190 counting rate must be corrected for decay occurring during the time between the yttrium milking and the counting of the Y90.

In a neutron-activated strontium sample $\mathrm{sr}^{85 \mathrm{~m}}, \mathrm{sr}^{85}, \mathrm{sr}^{87 \mathrm{~m}}$, and $\mathrm{Sr}^{89}$ will be observed. $\mathrm{Sr}^{89 \mathrm{~m}}$ may be present, but very little is known about this isomer of $\mathrm{sr}^{89}$. $\mathrm{Sr}^{89}$ is the only beta emitter in this group. The others enlt only gama rays and can be moasured with a scintillation counter. Again the short-lived activities can be permitted to decay, and only the 51 day $s^{89}$ and 64 day $s^{85}$ need be moasured. The gamma rays from the latter isotope can be easily distinguishod with a scintillation spectrometer.

In a fission product mixture all of the radioactive isotopes of strontium with mass numbers akove 88 may be present. $\mathrm{Sr}^{89}$ and $\mathrm{Sr}^{90}$ may be measured as discussed above. $\mathrm{Sr}^{91}$ and $\mathrm{Sr}^{92}$ emit both beta and gamma radiation and can be counted either with a Geiger or proportional counter or a scintillation counter. They have short half lives, however, so decay corrections must be made. $\mathrm{sr}^{93}, \mathrm{Sr}^{94}, \mathrm{sr}^{95}$, and $\mathrm{sr}^{97}$ are all bete emitters but they have very short half lives and nay not be observed. All of the short-lived isotopes can be permitted to decay, and only the $\mathrm{Sr}^{89}$ and $\mathrm{Sr}^{90}$ need be counted.

Berium-140 is used as a tracer in barium analysis. This isotope emits beta particles with upper energy limits of $1.0 \mathrm{Mev}$ and 
about $0.4 \mathrm{Hev}$ and several gand rays. Thus, it can be mosured either with a Geiger ar proportional counter or with a scintillation detector. $\mathrm{Ba}^{240}$ with a hale life of 12.80 days decays to 40 hour Iallo which aloo onits both bete perticles and gamma rays. At least 134 hours 62 may be allowed to elapse between the chemical separation and the radioussay to permit radioactive equilibrium to be eatablishod, or the Bllo can be separated from the $\mathrm{L}^{14}{ }^{140}$ and radicassayed before the $\mathrm{Le}^{1400}$ again becoms masurable. The separation of $\mathrm{Ba}^{24 \mathrm{O}}$ and $\mathrm{La}^{140} \mathrm{can}$ be porformed by preciptation of $\mathrm{BaCl}_{2} \cdot 2 \mathrm{H}_{2} \mathrm{O}^{62}$, by selectively eluting the $\mathrm{I}^{2} \mathrm{ILO}^{140}$ from an ion exchange colum 63 , or by extracting the La ${ }^{740}$ from $20.05 \mathrm{M} \mathrm{BCl}$ solution into a $1.5 \mathrm{M}$ solution of di(2-ethol hexyl) orthophosphoric acid in toluene 64.

In a neutron activation $\mathrm{Ba}^{131}, \mathrm{~B}^{133 \mathrm{~m}}, \mathrm{Ba}^{133}, \mathrm{Ba}^{135 \mathrm{~m}}, \mathrm{~B} 137 \mathrm{~m}$, and 139 may be produced. Blil with a half life of 11.5 days, 38.9 hour Ba $^{133 m}$, 7.2 year Be133, 28.7 hour B135m, and 2.6 mimute B137m ant only gamen rays and can be messured with a scintizlation detector, with appropriate decay corrections for the short half lives. The only bote emitter in this group is 84 minute Ba 139 , which also endts a $0.163 \mathrm{KeV}$ gamma ray.

In a fission product mixture short-1ived $\mathrm{Bn}^{141}, \mathrm{Ba}^{142}, \mathrm{Bn}^{143}$, and $\mathrm{Ba}^{144}$ mag be found in addition to $\mathrm{Ba}^{137} \mathrm{~m}, \mathrm{Ba} 139$, and $\mathrm{B}^{140}$. These higher-mss isotopes are all beta entters. If a flesion product mixture is allowed to decay for a fow hours before chemical separation, only 140 will remain; and it can bo permitted to come to equilibrium with its Iallo daughter or it can be counted before the Ial40 becomes masurable. 
๑

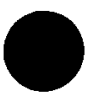




\section{INDEX OF PROCEDURES}

Bage

PROCEDURE 1

Barim ................... Sunderman (1957) 29

PROCEDURE 2

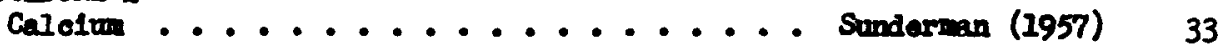

PROCGDURE 3

Strontium ....................... Sunderman (1957) 37

PROCEDURE 4

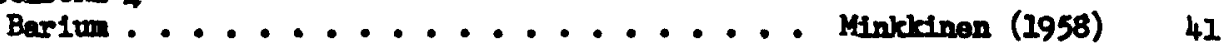

PROCEDURS 5

Barium . . . . . . . . Boavfalt and Lobons (1952) 45

PROCEDURE 6

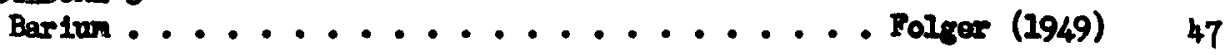

PROCEDURE 7

Bartwn . . . . . . . . Ifppann and Coockermann (1949) 48

PROCEDURE 9

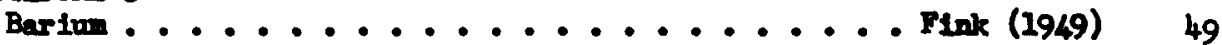

PROCEDURE 9

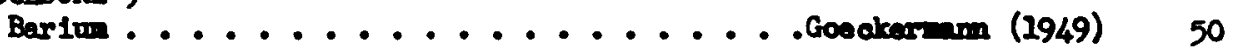

PROGESURE 10

Barium . . . . . Hicks, Folger, and Goodkermann (1949) 51

PROCEDURS 11

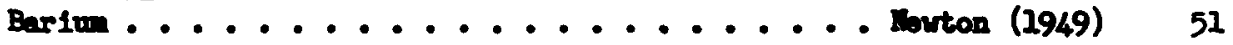

PROCGDURE 12

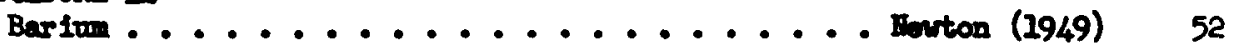

PROCEDURE 13

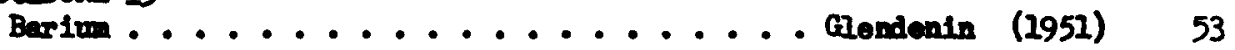

PROGEDURS $\mathbf{u}_{4}$

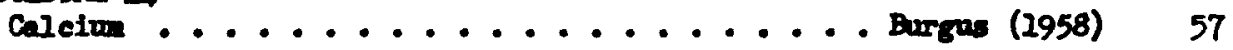

PROGEDUR 15

Calcion ............. Stemart and sortkg (2949) 61 
PROCDOURE 16

Calcium

Batrol (1949)

PROCEDURE 17

Calcium

PROCEDURE 18

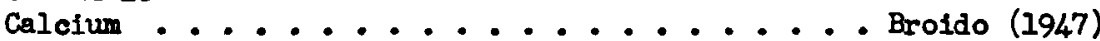

FROCEDURE 19

Strontium

PROCEDURE 20

Strontium . . . . . . . Boaufait and Lukens (1952) 71

PROCEDURE 21

Strontium

PROCEDURE 22

Strontium

PROCEDURE 23

Strontium

PROCEDURE 24

Strontium . . . . . L Lippmann and Goeckermann (1949) 76

PROCEDURE 25

Strontium . . . . . . . Folger and Hicka (1949) 76

PROCEOURE 26

Stront1um ......... Tompkins et al (195I) 78

PROCEDURE 27

Strontium ............ Orerstreet et al (1951) 79

PROCEDURE 28

Strontium . . . . . . Dalton and Welch (1956) 80

PROCEDURE 29

Strontium .............................. (1956) 83

PROCEDURE 30

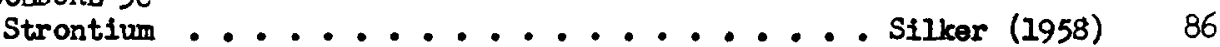

PROCEDURE 31

Strontium -...... Goldin, Velten, and Prishkorn(1959) 91

PROCEDURE 32

Strontium and Barium ............. Glendenin (1951) 97

PROCEDURE 33

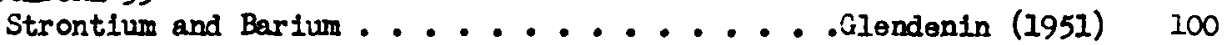

PROCEDURE 34

Strontium and Barium ............................. (1955) 104

PROCEDURE 35

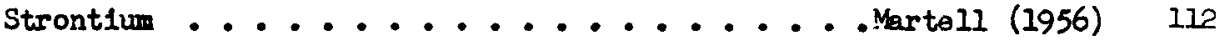

PROCEDURE 36

Strontium ............................ (1956) 
VII. COLIECTION OF DETATEED RADIOCHEMICAL FROCEDURES FOR BARIUM, CULCIUM, AND STRONTIUM

PROCEDURE 1

\section{Radiochemical Determination of Barium}

1. Introduction

A radiochemical procecture for barium has been developed from the yield and decontamination date presented in Tables 2 and 3 in Section IV. The procedure involves a separation of barium from strontium, calcium, and other contaminants by precipitation of $\mathrm{BaCl}_{2} \cdot 2 \mathrm{H}_{2} \mathrm{O}$ with an $\mathrm{HCl}$-ether reagent. This gives an 82 per cont yield for barium and results in a 50- to 100-fald decrease in contaminants for each cycle. The barium chloride precipitate is readily soluble in water, thus facilitating the recycling of the barium. The mothod is fast and efficient, and it requires no precautions other than those normally used in handing ether. The results are generally better than those of nitrate precipitations, because of the lower viscosity of the supernate, which allows more complete removal by suction tube. The berium is converted to a form suitable for counting and yield determinations by a final precipitation 28 the sulfate.

2. Equipment

Centrifuge

Centrifuge cones, borosilicate glass, graduated, with cone point, 15 ml. Stirring rods

Pipets, 1 ml.

Glass suction tabe connected to a vacuum flask - and through a trap to a water aspirator.

Planchets, 1 inch diameter flat stainless steel

3. Raagents

HCl-ether reagent: 4 volumes of ACS reagent grade hydrochloric acid to

1 volum of ACS reagent grade anhydrous ether (Mallinckrodt). Nitric acid, IM

Sulfuric acid, $10 \mathrm{ml}$ of concentrated acid, ACS reagent grade, per $100 \mathrm{ml}$ of water (about 1.8M). 


\section{Carriers (Depending Upon Suspected Contaminants)}

Intimony: $\mathrm{SbCl}_{3}, 10 \mathrm{mg} / \mathrm{ml} \mathrm{Sb} \mathrm{Sb}^{+3}$ in $3 \mathrm{M} \mathrm{HCl}$.

Barium: $\mathrm{Ba}\left(\mathrm{NO}_{3}\right)_{2}, 10 \mathrm{mg} / \mathrm{ml} \mathrm{Ba}^{+2}$ in water.

Calcium: $\mathrm{Ca}\left(\mathrm{NO}_{3}\right)_{2} \cdot 4 \mathrm{H}_{2} \mathrm{O}, 10 \mathrm{mg} / \mathrm{ml} \mathrm{Ca} \mathrm{Ca}^{* 2}$ in water.

Cerium: $\mathrm{Ce}\left(\mathrm{NO}_{3}\right)_{3} \cdot 6 \mathrm{H}_{2} \mathrm{O}, 10 \mathrm{mg} / \mathrm{ml} \mathrm{Ce} \mathrm{Ce}^{+3}$ in dilute $\mathrm{ENO}_{3}$.

Cesium: $\mathrm{C}_{3} \mathrm{Cl}, 10 \mathrm{mg} / \mathrm{ml} \mathrm{CB}^{+}$in water.

Chromium: $\mathrm{Cr}\left(\mathrm{NO}_{3}\right)_{3} \cdot 9 \mathrm{H}_{2} \mathrm{O}, 10 \mathrm{mg} / \mathrm{ml} \mathrm{Cr}^{+3}$ in dilute $\mathrm{HNO}_{3}$.

Cobalt: $\mathrm{Co}\left(\mathrm{NO}_{3}\right)_{2} \cdot 6 \mathrm{H}_{2} \mathrm{O}, 10 \mathrm{mg} / \mathrm{ml} \mathrm{Co}{ }^{+2}$ in water.

Iodine: $\mathrm{NaI}, 10 \mathrm{mg} / \mathrm{ml} \mathrm{I}$ in water.

Iridium: $\operatorname{IrCl}_{4}, 10 \mathrm{mg} / \mathrm{ml} \mathrm{Ir}^{\text {th }}$ in $0.1 \mathrm{M} \mathrm{HCl}$.

Ruthenium: $\mathrm{RuCl}_{3}, 10 \mathrm{mg} / \mathrm{ml} \mathrm{Ru}^{+3}$ in $0.1 \mathrm{M} \mathrm{HCl}$.

Selenium: $\mathrm{H}_{2} \mathrm{SeO}_{3}, 10 \mathrm{mg} / \mathrm{ml} \mathrm{Se}^{\text {th }}$ in $1.2 \mathrm{M} \mathrm{HCl}$.

Silver: ${ }_{4 \mathrm{gNO}}, 10 \mathrm{mg} / \mathrm{ml} / \mathrm{Ag}^{*}$ in water.

Strontium: $\mathrm{Sr}\left(\mathrm{NO}_{3}\right)_{2}, 10 \mathrm{mg} / \mathrm{ml} \mathrm{sr}^{2 / 2}$ in water.

Tantalum: $\mathrm{K}_{2} \mathrm{TaF}_{7}, 10 \mathrm{mg} / \mathrm{ml} \mathrm{Ta}^{45}$ - add $\mathrm{K}_{2} \mathrm{TaF}_{7}$ to $1 \mathrm{ml}$. of water containing one drop of conc. $\mathrm{ECI}$ and 1 drop of 1 to $1 \mathrm{HF}$ and haat to dissolve. Make up freah immediately before use because of instability.

Tin: $\mathrm{SnCl}_{2} \cdot 2 \mathrm{H}_{2} \mathrm{O}, 10 \mathrm{mg} / \mathrm{ml} \mathrm{Sn}^{+2}$ in $5 \% \mathrm{HCl}$

Zirconiun: $\mathrm{ZrO}\left(\mathrm{NO}_{3}\right)_{2} \cdot 2 \mathrm{H}_{2} \mathrm{O}, 10 \mathrm{mg} / \mathrm{ml} \mathrm{zr}^{4 \mathrm{~L}}$ in $0.5 \mathrm{M} \mathrm{HNO}_{3}$ and $0.1 \mathrm{M} \mathrm{HF}$.

5. Procedure

An outline of the procedure is given in Table 1 along with the yields and decontamination factors. A more complete description of ach step is given below.

Step 1. Add $10 \mathrm{mg}$ of carrier of the contaminating ion and $10 \mathrm{mg}$ of barium carrier to the solution of the sample in a $15 \mathrm{ml}$ centrifuge cone. Totel valume should be $3 \mathrm{ml}$. Composit carrier salutions can be prepared to reduce volume requirements. 


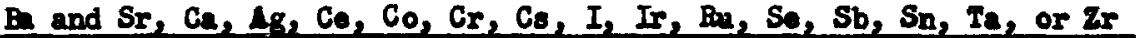

1. Idd carriers

2. Precipitate with $4: 1$ BCl-ether

3. Digest and centrifuge

4. Ronove supernate

\section{Decontanination factars}

$1-10 \mathrm{Sb}$

10-100 Ir, Sr, Bu, 2r

100-1000 $\mathrm{A}_{8}, \mathrm{Ca}, \mathrm{Ce}, \mathrm{Co}, \mathrm{Cr}, \mathrm{Cs}$,

$\mathrm{I}, \mathrm{Se}, \mathrm{Sn}, \mathrm{Ta}$

$\mathrm{BnCl}_{2} \cdot 2 \mathrm{H}_{2} \mathrm{O}$ Yield 828

5. Dissolve precipitate, add carriers Decontanination factors:

6. Reprecipitate with BCl-ether reagent

10-100 Sb

7. Digest and centrifuge

$10^{2}-10^{3}$ Ir, $\mathrm{Sr}$

8. Renove supermate

$10^{3}-10^{4} \mathrm{Ru}, \mathrm{z}_{\mathbf{r}}$

$10^{4}-10^{5} 4 g, C_{2}, C_{0}, C_{0}, C_{r}, C_{s}$,

$\mathrm{I}, \mathrm{Se}, \mathrm{Sn}, \mathrm{Ta}$

$\mathrm{BCI}_{2} \cdot 2 \mathrm{H}_{2} \mathrm{O}$ Iield $67 \%$

9. Dissolve precipitate, add carriers Decontamination factors:

10. Roprecipitate with HCl-ethor reagent

11. Digest and centrifuge

10-100 Sb

$10^{3}-10^{4}$ Ir

12. Rerove supernate

$10^{4-105} \mathrm{sr}$

105-107 48, $\mathrm{Ca}, \mathrm{Ce}, \mathrm{Co}, \mathrm{Cr}, \mathrm{Ca}$, $\mathrm{I}, \mathrm{Ru}, \mathrm{Se}, \mathrm{Sn}, \mathrm{Ta}, \mathrm{Zr}$

13. Dissolve precipitate, add carriers Decontand nation cactors:

14. Precipitate with $10 \% \mathrm{~B}_{2} \mathrm{SO}_{4}$ $10^{2}-10^{3} \mathrm{Sb}$

15. Digest and centrifuge $10^{4-10^{5}} \mathrm{Ir}$, sr $10^{6}-10^{8} 4 g, \mathrm{Ca}, \mathrm{Ce}, \mathrm{Cs}, \mathrm{mr}, \mathrm{zr}$

16. Remove Supernate $\downarrow 10^{8}-109 \mathrm{Co}, \mathrm{Cr}, \mathrm{I}, \mathrm{Se}, \mathrm{Sn}, \mathrm{Ta}$ $\mathrm{BuSO}_{4} \quad$ Yield $55 \%$

17. Transfer precipitate to plate and dry

18. Weigh precipitate for yield

19. Hount and count 
Stop 2. Precipitate $\mathrm{BCCl}_{2} \cdot 2 \mathrm{H}_{2} \mathrm{O}$ fram the 3 ml aqueous relum by addition of $10 \mathrm{ml}$ of the $\mathrm{KCl}$-ether reagent with thorough atirring.

Step 3. Digest for 5 nimtes at roon temperature with occasional stirring. Centrifuge for 5 minutes at top speed.

Step 4. Remove the supernate wil th the suction tube.

Step 5. Dissolve the precipitate in water and add a carrier for the contaminating ion. Bring the volume to $3 \mathrm{ml}$.

Steps 6, 7, and 8. Repeat Steps 2, 3, and 4 .

Step 9. Repeat Step 5.

Steps 10, 11, and 12. Repert Steps 2, 3, and 4 .

Step 13. Repent Step 5.

Step 14. Wake rolume to $10 \mathrm{ml}$ with $\mathrm{IM} \mathrm{ENO}_{3}$ and precipitate $\mathrm{BaSO}_{4}$ with addition of $1 \mathrm{ml}$ of $10 \% \mathrm{H}_{2} \mathrm{SO}_{4}$ with thorough stirring.

Step 15. Digest for 5 minutes at room temperature and centrifuge top speed for 5 minutes.

Step 16. Remove the supernate with suction tube.

Step 17. Slurry the precipitate onto a planchet and dry.

Step 18. Weigh the precipitate to determine the yleld.

Step 19. Hount in a counting chamber and count.

\section{Discussion}

If a ratio of $\mathrm{HCl}$-ether reagent volume to solution volume of $10: 1.5$ is used, the barium yleld can be increased to 92 per cent per cycle, but the contanination by strontium is increased by a factor of 4 . Calcium is not a significant interference in either case.

1 precipitate of $\triangle \mathrm{gCl}$ forms upon addition of the $\mathrm{HCl}$-ether reagent when silver is present, but it readily dissolves in excess reagent. 


\section{PROCXOURS 2}

\section{Radioched cal Dotorination of Calciun}

1. Introduction

A radiochemical procedure for celcium has been deroloped from the yield and decontanination date presented in Tables 2 and 3 in Saction IV. The procochure involves a nitrate procipitation of celciun with strontinn and bariun to separate the alkaline earths from contaminating activities, a sulfate precipitation to remove the barium and strontion, and a finel precipitation of calciun oxalate. The calciun yield in each nitrate precipitation cycle is 78 per cont, and 10 por cent 18 loat in the sulsto separation of barium and strontium.

\section{Equipment}

\section{Centrifuge}

Centrifuge cones, borosilicate glass, greduated, with cone point, $15 \mathrm{al}$. Stirring rods

Plpets, 1 m

Glass suction tube connected to a racum nask - and throogh a trap to a water aspirator.

Water beth, composed of 400 ml beaker containing 300 ml of water supported on a small hot plate.

Panchots, 1 inch dianotor Nat stainleas stool.

\section{Reagents}

Fuming nitric acid, $\Lambda$ CS reagent grade, 90 to 95 par cent $\mathrm{Hr}_{\mathrm{O}}$. Nitric acid, IY.

Sulfuric acid, 10 mil of concentreted acid, ICS reagent grade, per $100 \mathrm{ml}$ of water (about 1.8Y).

Amonium bydroxide, concentrated.

Amonium axalato, saturated solution in tar.

$$
\text { 4. Carriers }
$$

See Procedure 1. The carriers used in this procedure are the same as those used in the radiochemical determination of buriun. 
PROCADUR: 2 (Cont'd.)

5. Procedure

in outline of the procedure, with yields and decontamination factors, is giren in Table 1. A more complete discussion of each step is given below.

Step 1. Idd $10 \mathrm{mg}$ of carrier for strontium, barium, calcium, and the contaminating ions to the solution of the sample in a centrifuge cone.

Step 2. Idd sufficient fuming nitric acid precipitent and water to secure $80 \% \mathrm{HNO}_{3}$, and stir thoroughly.

Stop 3. Digest for 5 minutes at roon tempereture with occasional stirring, and centrifuge at top speed for 5 mimutes.

Step 4. Remove the supernate by decantation to waste storage for $\mathrm{HNO}_{3}$. Explosions are likely to occur if this solution is mxed with other wastes that may contain organic compounds.

Step 5. Dissolve the precipitate in water and add 10 mg of carrier for each contaminating ion.

Steps 6, 7, and 8. Repeat Steps 2, 3, and 4.

Step 9. Repeat Step 5.

Steps 10, 11, and 12. Repeat Steps 2, 3, and 4.

Step 13. Dissolve the precipitate in water.

Step 14. Make volume to $10 \mathrm{ml}$ with $\mathrm{IM} \mathrm{HNO}_{3}$, and precipitate $\mathrm{BaSO}_{4}$ and $\mathrm{SrSO}_{4}$ with addition of $1 \mathrm{ml}$ of $10 \% \mathrm{H}_{2} \mathrm{SO}_{4}$ with thorough stirring.

Step 15. Repeat Step 3.

Step 16. Decant the supernate into another centrifuge cone and discard the precipitate.

Step 17. Idd $10 \mathrm{mg}$ of carrier for strontium and barium.

Steps 18, 19, and 20. Repent Steps 14, 15, and 16.

Step 21. Repeat Step 17.

Steps 22, 23, and 24. Repeat Steps 14,15 , and 16 .

Step 25. Dilute the solution to $8 \mathrm{ml}$ with water and add sufficient 
PEOCAduic 2 (Cont'd.)

TAFE 1. RADIOCHEMICAL DETERRIINATION OF CAMCIUM

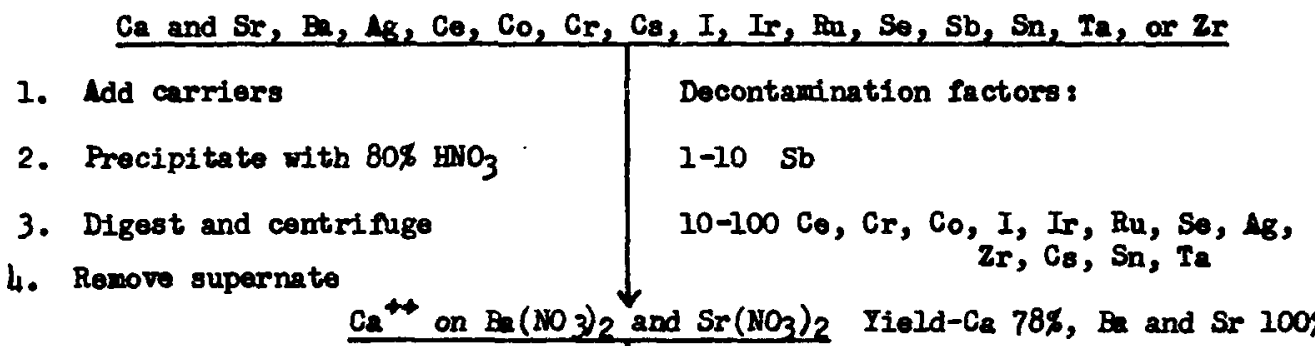

5. Dissolve precipitate and ald carriers

Decontanination factors:

6. Preclpitate with $80 \% \mathrm{HNO}_{3}$

1-10 Sb

7. Digest and centrifuge

$10^{2}-10^{3} \mathrm{Ce}$, Ir

8. Remove supernate 103-104 $\mathrm{Cs}, \mathrm{Cr}, \mathrm{Co}, \mathrm{Ia}_{\mathrm{Ta}}^{\mathrm{Iu}}, \mathrm{Zr}, \mathrm{So}, \mathrm{Sn}$,

$\mathrm{Ca}^{\text {t4 }}$ on $\mathrm{Pa}\left(\mathrm{NO}_{3}\right)_{2}$ and $\mathrm{Sr}\left(\mathrm{NO}_{3}\right)_{2}$ Yield-Ce $61 \%$, Be and $\mathrm{Sr} 100 \%$

9. Disaolve precipitate and add cerriers

Decontamination factors:

10. Precipitate with $80 \% \mathrm{BNO}_{3}$

1-10 Sb

11. Digest and centrifuge

$10^{4}-10^{5} \mathrm{Ce}, \mathrm{Co}, \mathrm{Ir}, \mathrm{Zr}$

12. Remore supernate $10^{5}-10^{6} \mathrm{Cs}, \mathrm{Cr}_{2} \mathrm{I}, \mathrm{Bu}, \mathrm{Se}, \mathrm{AB}_{\mathrm{B}} \mathrm{Sh}, \mathrm{Ta}$ $\mathrm{Ca}^{+4}$ on $\mathrm{Br}\left(\mathrm{NO}_{3}\right)_{2}$ and $\mathrm{Sr}\left(\mathrm{NO}_{3}\right)_{2}$ Yield-Ca $48 \%$, En and $\mathrm{Sr} 100 \%$

13. Dissolve precipitate

Decontanination factors 1-10 Sr

14. Precipitate with $10 \% \mathrm{H}_{2} \mathrm{SO}_{4}$

10-100 Sb, Ba

15. Digest and centrifuge

$10^{4}-10^{5} \mathrm{Ce}, \mathrm{Co}, \mathrm{Ir}, \mathrm{zr}$

16. Discard precipitate $10^{5}-10^{7} \mathrm{Cs}, \mathrm{Cr}, \mathrm{I}, \mathrm{Ru}, \mathrm{Se}, 4 \mathrm{~s}, \mathrm{Sn}, \mathrm{Ta}$ 
PROGEDORE 2 (Comt 1d)

TABRE 1. (CONTINUED)

17. Idd Sr and Ba carriers

18. Precipitate with $10 \% \mathrm{~B}_{2} \mathrm{SO}_{4}$

19. Digeat and centrifluge

20. Discard precipitate

21. Idd Sr and Be carriers

22. Precipitate with $10 \% \mathrm{H}_{2} \mathrm{Sq}_{4}$

23. Digest and centrifuge

24. Discard precipitate

25. Idd excess $\mathrm{NH}_{4} \mathrm{OH}$ and heat to bolling

26. Precipitate with $\left(\mathrm{NH}_{4}\right)_{2} \mathrm{C}_{2} \mathrm{O}_{4}$

27. Heat to boiling, digest, and centrifuge

28. Remove supernate

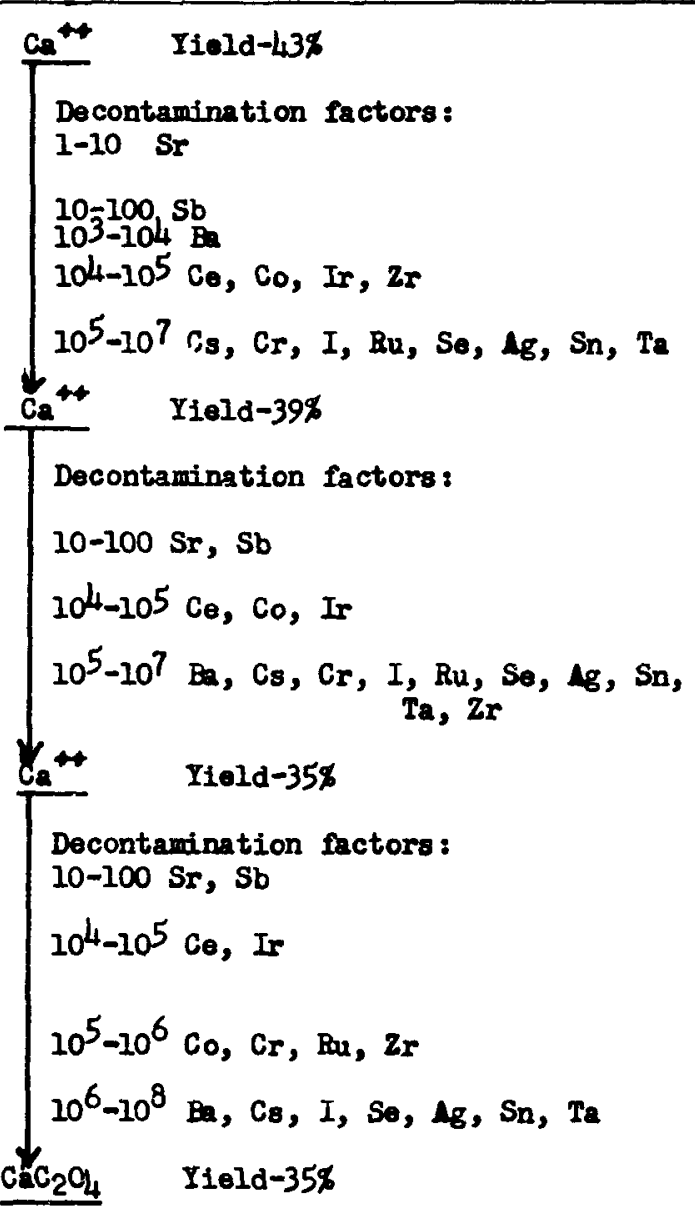

29. Transfer precipitate to plate and dry

30. Weigh precipitate for jield

31. Mount and count

concentrated $\mathrm{NH}_{4}$ OH to neutralize the acid and give an excess. One ml is usually satisfactory. Heat to boiling.

Step 26. Mdd 2 ml of a solution of saturated ammonium oxalate and stir thoroughly to precipitate $\mathrm{CaC}_{2} \mathrm{O}_{4}$.

Step 27. Heat again to boiling and allow to stana for 5 minutes without applying heat, while stirring occasionally. Centrifuge at top speed for 5 minutes. 
Step 28. Renove the supernate with the suction tube.

Step 29. Slurry the precipitate onto a planchet and dry.

Step 30. Weigh the precipitate to determine the yleld.

Step 31. Hount in a counting chamber and count.

6. Discussion

The precipitation of the barium and strontium nitrates nast be done in $80 \%$ nitric acid. If the concentration of the nftric acid ware lower, the coprecipitation of the calcium would be mach reduced. In 708 nftric acid only 13.4 per cont of the calciun is carried, and in $60 \%$ nitric acid only 3.5 par cent of the calcium is coprecipitated with the barium and strontium.

Care must be exercised in handling the suming nitric acid. The work should be done in a well rentilated hood, and the oparator should wear rubber gloves and a face shield to avoid severe acid burns.

\section{PROCEDURE 3}

Radiocbenical Detergination of Strontium

1. Introduction

1 radiochomical procedure for strontium has been dereloped from the yiold and decontamination data presented in Tables 2 and 3 in Section IV. The procedure involves a nitrate precipitation of strontium and barium, a chloride precipitation to remore the bariun, and a final precipitation of strontium oxalate. The nitrate precipitation is done in 60 per cont nitric acid to minimize the calcium contemination. The yield of atrontium nitrate is 81 par cent. About 3 per cent of the strontiun is precipitated with the $\mathrm{ECl}_{2} \cdot 2 \mathrm{H}_{2} \mathrm{O}$.

\section{Bquipment}

Centrifuge

Centrifuge cones, borostlicate glass, graduated, with cone point, 15 wl. Stirring rods 
Plpots, 1 ml

Glass suction tube connected to a vacum flask - and through a trap to a water aspirator.

Water bath, composed of $400 \mathrm{ml}$ beaker containing $300 \mathrm{ml}$ of water supported on a $8 \operatorname{mall}$ hot plate.

Planchets, I inch diameter flat stainless steel.

3. Keagents

Puming nitric acid, $1 \mathrm{CS}$ reagent grade, 90 to $95 \% \mathrm{HNO}_{3}$.

HCl-ether reagent: 4 rolumes of $A C S$ reagent grade hydrochloric acid to

I volume of ACS reagent grade anhydrous other (Mallinckrodt).

Amonius hydroxide, concentrated.

Ammonium axalate, saturated solution in water.

\section{Carriers}

See Procedure 1. The carriers used in this procedure are the sam as those used in the radiochemical determination of barium.

\section{Procedure}

An outline of the procedure, with yields and decontamination factors, is given in Table 1. A more complete discussion of each step is given below.

Step 1. Mdd $10 \mathrm{mg}$ of carrier for strontium, barium, and the contaminating ions to the solution of the sample in a centrifuge cone.

Step 2. Idd sufficient fuming nitric acid precipitant and water to secure $60 \% \mathrm{HNO}_{3}$, and stir thoroughly.

Step 3. Digest for 5 minutes at room temperature with occesional stirring, and centrifuge at top speed for 5 minutes.

Step 4. Remove the supernate by decantation to waste storage for $\mathrm{ENO}_{3}$. Explosions are likely to occur if this solution is mixed with other wastes that montain organic compounds.

Step 5. Dissolve the precipitate in water and add $10 \mathrm{mg}$ of carrier for each contaminating ion. 
Froctour 3 (Cont'd.)

Steps 6, 7, and 8. Bepeat Stops 2, 3, and 4 .

Step 9. Dissolve the precipitate in 3 m of water.

Step 10. Precipitate $\mathrm{BCCl}_{2} \cdot 2 \mathrm{H}_{2} \mathrm{O}$ fran the 3 al aquecus volum by addition of $10 \mathrm{ml}$ of the $\mathrm{BCl}$-ether reagent with tharongh stirring.

Stop 11. Repeat Step 3.

TAEL 1. RADIOCHGMCAL DETERMTNATION OF STROMTIUM

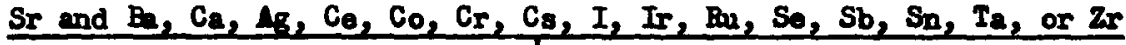

1. Idd carriers

2. Precipitate with $60 \% \mathrm{ENO}_{3}$

3. Digest and centrifuge

4. Rewove supernate
Decontamination factors:

1-10 Sb

10-100 $\mathrm{C}_{2}, \mathrm{Ce}_{8}, \mathrm{C}_{8}, \mathrm{C}_{0}, \mathrm{Ru}, \mathrm{Se}, 48, \mathrm{Sn}, \mathrm{zr}$

100-1000 Cr, I, Ir, Ia

$\mathrm{Ba}\left(\mathrm{NO}_{3}\right)_{2}$ and $\mathrm{Sr}\left(\mathrm{NO}_{3}\right)_{2}$ Yield-Sr 81\%, Be $86 \%$

5. Dissolve precipitate and add

Decontamination factors: carriers

$10-100 \mathrm{Sb}$

6. Precipitate with $60 \% \mathrm{HNO}_{3}$

$10^{2}-10^{3} \mathrm{Ca}, \mathrm{Co}, \mathrm{zr}$

7. Digest and centrifuge

$10^{3}-10^{4} \mathrm{Co}, \mathrm{C}_{8}, \mathrm{Cr}_{\mathrm{r}}, \mathrm{Br}, \mathrm{Se}, \mathrm{Ag}$, Sin

8. Renove supernate

$10^{4-10^{5}} \mathrm{I}, \mathrm{Ir}, \mathrm{Ta}$

$\mathrm{Bn}\left(\mathrm{NO}_{3}\right)_{2}$ and $\mathrm{Sr}\left(\mathrm{NO}_{3}\right)_{2}$ Tield-Sr 66\%, B $74 \%$

9. Dissolve precipitate

Decontemination fectors:

1-10

10. Precipitate $\mathrm{BaCl}_{2} \cdot 2 \mathrm{H}_{2} \mathrm{O}$ with bC1-ether

$10-100 \mathrm{Sb}$

$10^{2}-10^{3} \mathrm{Ca}, \mathrm{Co}_{0}, \mathrm{zr}$

11. Digest and centrifuge

$10^{3}-10^{4} \mathrm{Ce}, \mathrm{Cs}, \mathrm{Cr}, \mathrm{Ru}, \mathrm{St}, \mathrm{Ag}_{\mathrm{g}} \mathrm{Sn}$

12. Discard prectpitate

$10^{4}-10^{5} \mathrm{I}, \mathrm{Ir}$, Ta

st Yield-64\%

13. Idd barium carrier to precipitate $\mathrm{BaCl}_{2} \cdot 2 \mathrm{H}_{2} \mathrm{O}$

14. Digest and centrifluge

15. Discard precipiteto

Decontanination factore:

10-100 Be, Sb

$10^{2}-10^{3} \mathrm{Ca}, \mathrm{Co}, \mathrm{Zr}$

$10^{3}-10^{4} \mathrm{Ce}_{e}, \mathrm{C}_{s}, \mathrm{Cr}_{r}, \mathrm{~Hz}, \mathrm{Se}, \mathrm{Ag}, \mathrm{Sn}$

$10^{4-10^{5}} \mathrm{I}, \mathrm{Ir}, \mathrm{Ta}$ 


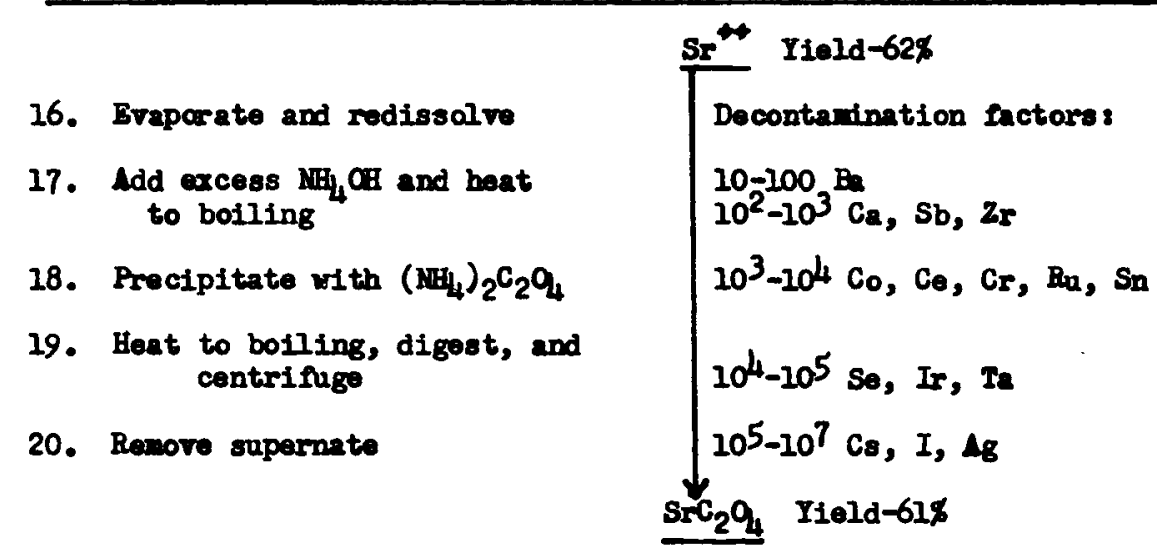

21. Transfer precipitate to plate and dry

22. Weigh precipitate for yield

23. Kount and count.

Step 12. Decant the supernate into another centrifuge cone and discard the precipitate.

Step 13. Idd $10 \mathrm{gg}$ of thearrier. $\mathrm{BCCl}_{2} \cdot 2 \mathrm{H}_{2} \mathrm{O}$ will precipitate.

Steps 14 and 15. Repeat Stepe 11 and 12.

Stop 16. Bvaporato the BCI-other supermate and redissolve tho reaidue in 8 il of rater.

Step 17. Add sufficient $\mathrm{NH}_{4} \mathrm{OH}$ to make the solution basic, and heat to boiling.

Step 18. Add 2 al of a solution of saturated amoniun oxalate and atir thoroughts to precipitate $\mathrm{SrC}_{2} \mathrm{O}_{4}$.

Step 19. Heat again to boiling and allow to stand for 5 minutes without applying heat, while stirring occasionally. Centrifuge at top speed for 5 minutes.

Step 20. Renove the supernate with the suction tube.

Step 21. SIurry the precipitate onto a planchet and dry.

Step 22. Weigh the precipitate to determine the yield.

Step 23. Hount in a counting chamber and count. 


\section{PROCHOUE 3 (Cont'd.)}

\section{Discusaton}

The precipitation of the strontiun and barium nitrates is dono in $60 \%$ niteric acid to ninimize the calciur contarination. At this acid concentration only 3.5 per cont of the celcium is coprecipitated with the strontiun and barium, but at a concentration of 70 per cont, 23.4 per cant of the calcium is carried. If the acid concontration gots as high 2880 par cont, 78 per cent of the calcinm is carried.

Care mat be exercioed in handing the furing nitric acid. The work should be done in a well rentilated hood, and the oparator should wear rabber gloves and a face shield to aroid severe acid burns. Cood rentilation should also be provided for the thor, and it should not be brought close to opan flams.

\section{PROCEDURB 4}

\section{BMPIM}

Source - C. 0. Minklinen in "Collected Badiochendical Procedures", Los Llamos report IL-1721. Jan. 1958.

The procedure for the separation and determination of barium is a modification by C. O. Minkklinen of one described by L. E. Giendemin, CC-971 (September 15, 1943).

\section{Introduction}

Bariun may be separated from fission-product material by the specific procipitation in the cold as $\mathrm{BaCl}_{2} \cdot \mathrm{H}_{2} \mathrm{O}$ y mans of a concentrated hydroci $=$ ic acid-ethyl ether mixture. The procedure for the determination of barium as outlined below consists in the isolation of $\mathrm{BCCl}_{2} \cdot \mathrm{H}_{2} \mathrm{O}$, followed by conversion to the chromate. Three precipitations of the chloride are carried out, the first and second being followed by ferric hydroxide scavenging steps. The final precipitation of barium as the chromate is preceded bo a lanthanum hydroxide scavenging step to remove lanthanum and other fission products which form insoluble bodroxides and which ware not removed by the iron scavenger. 


\section{PROCHDUid 4 (Cont'd.)}

The chemical yield of bariun chromate is 65 to $75 \%$. A single analysis requires about 2 hours.

\section{Rergents}

Be carrier: $10 \mathrm{mg} \mathrm{Ba} / \mathrm{ml} \mathrm{Ba}\left(\mathrm{NO}_{3}\right)_{2}$ solution--standardized

Fe carrier: $10 \mathrm{mg} \mathrm{Fe} / \mathrm{ml}$ (added as aqueous $\mathrm{FeCl}_{3} \cdot 6 \mathrm{H}_{2} \mathrm{O}$ )

La carrier: $10 \mathrm{mg} \mathrm{La} / \mathrm{ml}$ (added as aqueous $\mathrm{La}\left(\mathrm{NO}_{3}\right)_{3} \cdot 6 \mathrm{H}_{2} \mathrm{O}$ )

HCl-ethyl ether mixture: 5 parts (by volume) conc. HCl to 1 part ethyl ether $\mathrm{NH}_{4} \mathrm{OH}: 6 \mathrm{M}$

NH4 $\mathrm{OH}: \quad$ II

HCI: 6 M

$\mathrm{HC}_{2} \mathrm{H}_{3} \mathrm{O}_{2}: 6 \mathrm{H}$

$\mathrm{NH}_{4} \mathrm{C}_{2} \mathrm{H}_{3} \mathrm{O}_{2}: \quad 3 \mathrm{M}$

$\mathrm{N}_{2} \mathrm{CrO}_{4}: 1.5 \mathrm{H}$

Phenolphthalein indicator solution

Ethanol: 95\%.

\section{Equipment}

Drying oven

Centrifuge

Hot plate

Fisher burner

Block for holding centrifuge tubes

Forceps

Mounting plates

15-ml sintered glass crucible (fine porosity)

Ground-off Hirsch funnels: Coors 000 (one per sample)

Filter chimeys (on per sample)

Filter flask (one per sample)

250-ml beakers (one for each standardization)

Pipets: 2- and 5-mi 
Frocturnes 4 (Cont'd.)

Wash bottlo

40-ml conical centrifuge tubes: Pyrex 8320 (four per sample)

No. 50 Whatman filter paper: 7/8 dianoter

Stirring rods

Ice bath.

4. Preparation and Standardization of Carrier

Dissolve $19.0 \mathrm{gm}$ of $\mathrm{Ba}\left(\mathrm{NO}_{3}\right)_{2}$ in $\mathrm{H}_{2} \mathrm{O}$ and dilute to 1 liter.

Pipet $5.0 \mathrm{ml}$ of carrier solution into a 250-ml besker and dilute to approximately $100 \mathrm{ml}$. Add $5 \mathrm{ml}$ of $6 \mathrm{M} \mathrm{HC}_{2} \mathrm{H}_{3} \mathrm{O}_{2}$ and $10 \mathrm{ml}$ of $3 \mathrm{M} \mathrm{NH}_{4} \mathrm{C}_{2} \mathrm{H}_{3} \mathrm{O}_{2}$. Place on hot plate and bring to a boil. Ldd $5 \mathrm{ml}$ of $1.5 \mathrm{M} \mathrm{Na}_{2} \mathrm{CrO}_{4}$ dropwise with stirring, boll for 1 min with stirring, cool to room telperature, and filter the $\mathrm{BaCrO}_{4}$ on a fine sintered glass crucible which has been washed with water andethanol, dried at $110^{\circ}$ for $15 \mathrm{~min}$, and weighed. Wash the precipitate three times with 5-ml portions of $\mathrm{H}_{2} \mathrm{O}$ and three times with 5-ml portions of ethanol. Dry at $110^{\circ}$, cool, and weigh.

Four standardizations of the carrier solution are performed. The spread in results is about $0.5 \%$.

\section{Procedure}

Step 1. To the sample in a 40-ml centrifluge tube, add $2 \mathrm{ml}$ of standardized carrier (combined volume not to exceed $5 \mathrm{ml}$ ). Place tube in ice beth and add $30 \mathrm{ml}$ of cold HCl-ether reagent (Note 1). Stir for $1 \mathrm{~min}$ or until a precipitate of $\mathrm{BaCl}_{2} \cdot \mathrm{H}_{2} \mathrm{O}$ is formed. Centrifugo and discard the supernate. Whathingrecipitate twice with 5 ml of HClether mixture, centrifluging after each eashing and discarding the supernate.

Step 2. Dissolve procipitate in $4 \mathrm{ml}$ of $\mathrm{H}_{2} \mathrm{O}$. Add 1 drop of phenolphthalein solution and 6 drops of Fe carrier. Neutralize with 64 N/4 and add 12 drops in excess. Centrifuge and pour the supernate into a clean centrifuge tube. 
Step 3. Ldd $30 \mathrm{ml}$ of BCl-ether mixture to the supernate and proceed as in Stops 1 and 2.

Step 4. Repeat precipitation of $\mathrm{BaCl}_{2} \cdot \mathrm{H}_{2} \mathrm{O}$ wi th $\mathrm{HCl}$-ether reagent. Wash precipitate twice with 5-ml portions of $\mathrm{BCl}$-ether reagent, dissolve precipitate in $10 \mathrm{ml}$ of $\mathrm{H}_{2} \mathrm{O}$, and add 1 drop of phenolphthalein solution and 10 drops of La carrier. Neutralize with $6 \mathrm{M} \mathrm{NH}_{4} \mathrm{OH}$ and add 10 drops in excess. Centrifuge and pour the supernate into centrifuge tube. Wash precipitate twice with $5-\mathrm{ml}$ portions of $\mathrm{IM} \mathrm{NH}_{4} \mathrm{OH}$, adding the washings to the supernate from scavenger precipitation.

Step 5. Noutralize supernate with 6M HCl, and then add $2.5 \mathrm{ml}$ of $6 \mathrm{M} \mathrm{HC}_{2} \mathrm{H}_{3} \mathrm{O}_{2}$ and $10 \mathrm{ml}$ of $3 \mathrm{M} \mathrm{NH}_{4} \mathrm{C}_{2} \mathrm{H}_{3} \mathrm{O}_{2}$. Heat to boiling and add dropwise $2 \mathrm{ml}$ of $1.5 \mathrm{M} \mathrm{Na}_{2} \mathrm{Crq}_{4}$. Boil for $1 \mathrm{~min}$ with constant stirring. Cool and filter the $\mathrm{BaCrO}_{4}$ on a previously washed, dried, and weighed filter paper, using a filter chimey and ground-off Hirsch funnel. Wash the preclpitate three times with 5-ml portions of $\mathrm{H}_{2} \mathrm{O}$ and three times with 5-ml portions of ethanol. Dry at $110^{\circ}, \operatorname{cool}$, weigh, and mount (Note 2).

\section{Notes}

1. For maximum yield of $\mathrm{BaCl}_{2} \cdot \mathrm{H}_{2} \mathrm{O}$ the solution mat be cooled to about $5^{\circ}$.

2. The $\mathrm{BCrO}_{4}$ precipitates are set aside for 134 hours before counting. This permits $\mathrm{B}^{140}$ and the $\mathrm{L}^{14} \mathrm{I}^{\mathrm{O}} \mathrm{O}$ daughter activities to como to equilibrium. 


\section{PROCEDUR 5}

BARIUY

Solution - L. J. Benufatt, Jr., and H. B. Lukans, Jr., page 77 in

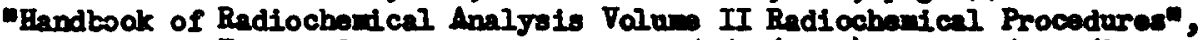

U. S. Atoxic Bnarg Comission report NP-5057 (Dal.), thrch 5, 1952.

1. To the solution containing the bariun setirity in a volum of 5 to 8 al (in a 40-wl boayg-wall contrifuge com), add beriun carrier, stir thoroughly and let stand for ten aimutes. Idd 20 al of yellow funing $\mathrm{HWO}_{3}$ to precipitate $\mathrm{Ba}\left(\mathrm{HO}_{3}\right)_{2}$ (Note a). The solution is stirred whilo cooling in an ice bath for five nimtes. Centrifnge, decant, and discard the supernate.

2. Dissalve the precipitate completaly in 2 ml of water (Hote b). Heprecipitate $\mathrm{B}\left(\mathrm{NO}_{3}\right)_{2}$ by adding $10 \mathrm{~m}$ of roding $\mathrm{HrO}_{3}$ and cooling in an 1ce bath for 20 mimtes with occasional stirring. Centrifuge the solution, decant, and discard the supernete. Diseolve the precipitate in 7 ill of mater.

3. Idd 5 ig of Fe carrier and precipitate Fo(OA) 3 by the addition of 2 il of 6N Ih $_{4}$ OH while atirring (Note $c$ ). Centrifuge and trans for the supornate with a pipetto to a clean $40-i$ contrilage cono. Wash the procipitate

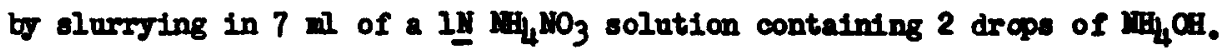
Centrifuge and ramove the wash supernate with a transfor pipotte. Combine this wash supernate with the supernate above and seve. Discard the $\mathrm{Fo}(\mathrm{OH})_{3}$ scavenge precipitate.

4. Neutralise the combined supernates by the droparise addition of $6 \mathrm{y}$ $\mathrm{HNO}_{3}$, testing the acidity vith $\mathrm{pH}$ paper. Add $1 \mathrm{ml}$ of $6 \mathrm{~K}$ Hce and 2 al

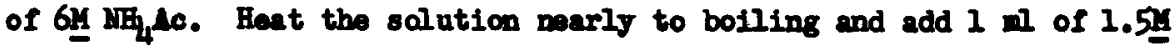
He $\mathrm{CrO}_{4}$, droparise with stirring. Contime stirring the soluticn for one rimte, then centrifuge. Discard the supernate. Wagh the jellow Barg 4 with $10 \mathrm{ml}$ of hot water. Contrifuge and discand the supernate. The remaining steps in the procedure, including the final counting, mast 
be Iinished within two howrs to prevent error due to La140 daughter contanination in the precipitate.

5. Dissalve the $\mathrm{BaCrO}_{4}$ in 2 wl of 6N BCI (Note d). Add 15 wl of BCl-etbor reagent, and stir for two mimites to cangulate the $\mathrm{BCCl}_{2}$ and let stand for IIro mintes in an ice bath. Centrifuge the solution, decant, then discard the supernate.

6. Dissolve the precipitate in a fov drops af water (Note b), and reprecipitate the $\mathrm{BCCl}_{2} \cdot \mathrm{H}_{2} \mathrm{O}$ by the addition of $15 \mathrm{ml}$ of $\mathrm{HCl}$-ether reagent and stir the solution for two mimtes. Nllow the solution to cool in an ice bath for five minutes. Centrifuge, decent, end discard the supernate.

7. Have ready a Whatman No. 42 peper disc which has been previously prepared by washing it with three 3-ml portions of water and three 3-il portions of ethanol. Dry in an oren at $90-100^{\circ}$ for 15 minutes, cool in

a desiccator for ten minutes, and weigh. Repeat this procedure until constant weight $( \pm 0.1 \mathrm{mg})$ has been obtained.

8. Dissolve the $\mathrm{BCCl}_{2}$ in $10 \mathrm{ml}$ of vater. Heat the solution nearly to boiling and add 5 drops of $1.5 \mathrm{M} \mathrm{H}_{2} \mathrm{SO}_{4}$. Continue beating for three minutes to coagulate the precipitate, then filter onto the prepared fllter paper. Wash and dry the precipitate according to the filter paper treatment in step 7. Weigh as $\mathrm{BaSq}_{4}$, nount, and count imediately (Note e).

\section{NOTES}

a. It least 3 volumes of funing nitric acid should be added to insure quantitative precipitation of $\mathrm{Bn}\left(\mathrm{MO}_{3}\right)_{2}$.

b. It ma be necsary to add sereral additional drops of water to effect complete solution.

c. The addition of several drops of $1 \%$ aerosol solution somtimes prevents excess creopage.

d. A precipitate of white $\mathrm{BCl}_{2}$ may appear but will dissolve with the addition of $0.5 \mathrm{ml}$ of water.

6. The counting error due to growth of the $\mathrm{L}^{140}$ daughter will become 


\section{Proctoula 5 (Cont'd.)}

appreciable (approxinately 3\%) aftar two hours from the $\mathrm{BCrO}_{4}$ procipitation. I curvo, Burium 140 -Lanthanew 140 Growth", is provided in Vol. I, Section two in case the two hour tim lint cannot be met.

\section{PROCEDURR 6}

\section{BARIUM}

Source - R. I. Folger in report AECD-2738

edited by W. W. Heinke, lugust 1949.

Target matertal: Approxtmately $3 \mathrm{~B}$ 0 motal

Type of bombardment: 184" high energy particles
Time for seperation: Approximately $1-1 / 2 \mathrm{hr}$.

Equipment requifed: Contrifuge, cones $(50 \mathrm{ml}-2 \mathrm{I})$, Ice bath.

\section{Iteld: 50-75\%}

Degree of purification: Approximately 103 from other elements - suffictent for mass spectrograph or Ion exchange column.

Ldvantages: itves good gield of Ra-Ba with only approximately $75 \mu g$ carrier.

Procedure:

(1) Dissolve target in small amount conc. $\mathrm{HMO}_{3}$ (heat if nocessary). Idd $100 \mu \mathrm{g} \mathrm{Ba}$ (as Ba $\left(\mathrm{NO}_{3}\right)_{2}$ carrier solution) and $20 \mathrm{gg} \mathrm{Sr}{ }^{+2}$ carrier (as nitrate).

(2) Idd fuming Hio to make up acoroximately $25 \mathrm{ml}$ and chill in ice bath for 10 minutes. Centrifuge out $\mathrm{Sr}\left(\mathrm{NO}_{3}\right)_{2}$ (Carrtes $\mathrm{Ba}$ and $\mathrm{Ra}$ ).

(3) Dissolve in $\mathrm{B}_{2} \mathrm{O}$, transfer to $15 \mathrm{ml}$ conc and buffer with Hac +

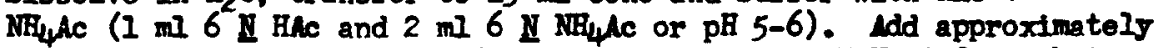
$5 \mathrm{mg} \mathrm{Pb}$ and precipitate $\mathrm{PbCrO}_{4}$ by addition of $1.5 \mathrm{H} \mathrm{Na}_{2} \mathrm{CrO}_{4}$ to hot solution. Wash with hot He and $\mathrm{NH}_{4}$ le boffer ( $1 \mathrm{mI}$ to $2 \mathrm{ml}$ as above) containing 1 drop $1.5 \mathrm{~N} \mathrm{Na}_{2} \mathrm{CrO}_{4}$.

(4) Dissolve precipitate in hot $2 \mathrm{~N} \mathrm{HCI}$, pass in $\mathrm{F}_{2} \mathrm{~S}$ to reduce $\mathrm{Cr}_{2} \mathrm{O}_{2}=$ to $\mathrm{Cr}^{+3}$ and dilute to $0.2 \mathrm{~N}$, precipitate $\mathrm{PDS}$ scavenge with few mg Cus.

(5) Boif out $\mathrm{H}_{2} \mathrm{~S}$, make basic with $\mathrm{NH}_{3}$ and precipitate $\mathrm{SrCO}_{3}$ by adding $2 \mathrm{mg} \mathrm{Sr}$ and a few drops $2 \mathrm{II} \mathrm{N}_{2} \mathrm{CO}_{3}$.

(6) Dissolve $\mathrm{SrCO}_{3}$ in 1 drop $6 \mathrm{~N} \mathrm{HCl}$, boil ont $\mathrm{CO}_{2}$, buffer whth $1 / 2$

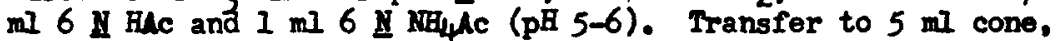
adding not more than $1 \mathrm{ml} \mathrm{H}_{2} \mathrm{O}$. Beat to near bolling, add minimum $\mathrm{Pb}^{+2}$ to prectpitate $\mathrm{PbCrO}_{4}$ with 1 drop $1.5 \mathrm{Na}_{2} \mathrm{CrO}_{4}$. Centrifuge.

(7) Dissolve $\mathrm{PbCrO}_{4}$ in 1 drop conc. HCl. Transfer to $2 \mathrm{ml}$ cone with $1 \mathrm{ml} H \mathrm{HCl}$-ether reagent. Chill $10 \mathrm{~min}$ in ice bath and centrifuge out $\mathrm{BaCl}_{2} \cdot 2 \mathrm{H}_{2} \mathrm{O}$. Wash with $\mathrm{I} / 2 \mathrm{ml} \mathrm{HCl}$-ether reagent.

(8) Dissolve in 1 drop $\mathrm{H}_{2} \mathrm{O}$ and add 1 drop $0.5 \mathrm{I} \mathrm{H}_{2} \mathrm{Sq}_{4}$. Contrifluge out $\mathrm{BSO}_{4}$ for sase spoctrograph. 
(8a) Dissolve in 1 drop $\mathrm{H}_{2} \mathrm{O}$ and add 1 drop 0.5 N WhOH plus 1 drop $2 \mathrm{H}$ $\mathrm{Ln}_{2} \mathrm{CO}_{3}$. Centrifrgo $\mathrm{BCO}_{3}$ and diseolve in $0.7 \mathrm{~A}$ BCI for equilibrätion with resin for colum run.

Remark: If the target solution is obtained in large ralue, buffer with IIf Ac until uraniun precipitates out. Centrifuge and precipitate $\mathrm{PbCrO}_{4} \mathrm{Tr}$ on supernatant (20 mg or nore my be required). Renore $\mathrm{Pb}$ by dissolving the chromate in 1-2 N HCl, passing in $\mathrm{H}_{2} \mathrm{~S}$, diluting to $0.2 \mathrm{~N}$ and precipitation PbS. Lfter $\mathrm{H}_{2} \mathrm{~S}$ has been bolled out, the solution wo be made basic and $\mathrm{SrCO}_{3}$ precipitated to reduce the rolues. Fallow with $\mathrm{Sr}\left(\mathrm{NO}_{3}\right)_{2}, \mathrm{PbCrO}_{4}$ and $\mathrm{ECI}_{2} \cdot 2 \mathrm{H}_{2} \mathrm{O}$ procipitations.

For mass spectrograph work, oteps 5 and 6 ma be replacod by

(5-6a) Boil out $\mathrm{H}_{2} \mathrm{~S}$. Buffer to $\mathrm{pH} 5-6$ and precipitate ain. $\mathrm{PbCrO}_{4}$ by addition of $\mathrm{Pb}^{+2}$ and 1.5 I $\mathrm{Kag}_{2} \mathrm{CrO}_{4}$. Contrifuge. Wash with 2 drops 6 II Nilic.

To remote excess alkali salts add:

(9) Tumo $\mathrm{BnSO}_{4}$ to dryness to remove ang $\mathrm{MH}_{4} \mathrm{Cl}$. Take up in I drop $0.5 \mathrm{~N} \mathrm{H} \mathrm{SO}_{4}$ - Contris ruge and rewash with i drop $0.5 \mathrm{~N} \mathrm{E}_{2} \mathrm{SO}_{4}$.

For resin colum separation of $\mathrm{Sr}, \mathrm{Br}$, and $\mathrm{B} 2$ see B. B. Tomplins MECD-1998. Glute tron resin with citrate at $\mathrm{pH}$ 7.5-8.0.

\section{PROCEDORE 7}

\section{BARIOM}

Source - D. Z. Itppmam and R. H. Ooeckermann in report AECD-2738 edited by W. W. Keinke, August 1949.

Target material: lu foll, about $1 \mathrm{~g}$ Time for separation: $1 \mathrm{hr}$. for bartum.

Type of bombardment: Full energy protons, helium tons, or deuterons

Bquipment required: Ice bath and hot water bath.

Yield: Ba 25\%

Degree of purification: Good - about $10^{5}$ from Au and spallation products and at least $10^{3}$ from fission products.

Advantages: $\mathrm{Sr}, \mathrm{Ba}$, and $\mathrm{Yo}$ can all be separated from the same target material.

Procedure: Dissolve target in hot solution containing $10 \mathrm{mg}$ each of Sr, $\mathrm{Ba}$, and $\mathrm{MO}, 5 \mathrm{ml}$ of $12 \mathrm{M} \mathrm{HCI}$ and $5 \mathrm{ml}$ of fuming $\mathrm{HNO}_{3}$. Cool solution in ice bath and slowly add about $30 \mathrm{ml}$ fuming $\mathrm{HNO}_{3} \cdot \mathrm{Sr}\left(\mathrm{NO}_{3}\right)_{2}$ and $\mathrm{Ba}\left(\mathrm{NO}_{3}\right)_{2}$ prectpitate. Centrifuge.

Dissolve precipitate in $5 \mathrm{ml} \mathrm{H}_{2} \mathrm{O}$, add $5 \mathrm{mg} \mathrm{Fe}$, warm in hot water bath, and precipitate $\mathrm{Fe}(\mathrm{OH})_{3}$ with $6 \mathrm{NH} \mathrm{NH}_{4} \mathrm{OH}$. Centrifuge. If destred add more $\mathrm{Fe}$ and centrifuge out $\mathrm{Fe}(\mathrm{OH})_{3}$ again. Neutralize supernatant with a few drops of $6 \mathrm{H} \mathrm{HC}_{2} \mathrm{H}_{3} \mathrm{O}$, heat to bolling, and add $2 \mathrm{ml}$ of $1.5 \mathrm{H} \mathrm{Na} \mathrm{CrO}_{4}$ dropwise. Digest $\mathrm{BaCrO}_{4}$ precipitate in hot water bath and centrifuge. 
Wash $\mathrm{BaCrO}_{4}$ precipitate with $10 \mathrm{ml}$ of hot $\mathrm{H}_{2} \mathrm{O}$ and centrifuge. Dissolve $\mathrm{BaCrO}_{4}$ in $1 \mathrm{ml}$ of $6 \mathrm{~K} \mathrm{BCl}$ with heating, add $10 \mathrm{mg}$ st carrior, $2 \mathrm{ml} 6 \mathrm{y}$

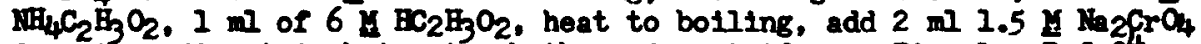
droputse, digest in hot water bath, and centrifuge. Dtssolve BaCrof in 1 ml $6 \mathrm{M} \mathrm{HCI}$ with heating, add 15 ml HGI-other reagent $(5$ volumes of $12 \mathrm{I} \mathrm{BCI}$ plus 1 volure of other), cool in tce bath unt $11 \mathrm{BaCl}_{2}$ prectpitates, and centrifuge. Dissolve $\mathrm{BaCl}_{2}$ in $5 \mathrm{ml} \mathrm{H}_{2} \mathrm{O}$, add 5 mg

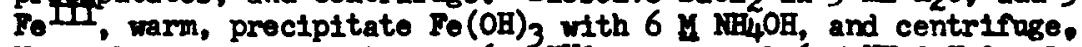

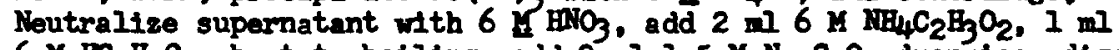
$6 \mathrm{~K} \mathrm{BC}_{2} \mathrm{~B}_{3} \mathrm{O}_{2}$, heat to botling, add $2 \mathrm{ml} 1.5 \mathrm{H} \mathrm{Na}_{2} \mathrm{CrO}_{4}$ dropurise, difest in hot water bath, filter, wash three times with $5 \mathrm{mz} \mathrm{H}_{2} \mathrm{O}$ and three times with $5 \mathrm{ml}$ alcohol, dry 15 minutes at $110 \mathrm{C}$. Weigh as $\mathrm{BaCrO}_{4}$.

Romarks:

$M I$ additions of funting or concentrated $\mathrm{HnO}_{3}$ should be made cantiouslys they tend to react violently after a short induction pertod.

\section{PROCEDURE 8}

\section{BARITM}

Source - R. W. Fink in report $A B C D-2738$

odited by W. W. Heinke, August 1949.

Target material: COCL Tine for separation: $90 \mathrm{~min}$.

Type of bombardment: ' 85 Yov Protons Equipment required: Standard for 1 hour

Iield: Sufficient for mass spectrograph work.

Degree of purification: Cesiun ts cersistent, but may be removed in successive recyclings. Pure enough for mass spectrograph work.

Idvantages:

Carrier free Ba for mass spectrograph.

Procedure:

(1) Target $\mathrm{CsCl}$ is dissolved in 2 ce $0.3-\mathrm{N} \mathrm{Hhc,} \mathrm{I} \mathrm{ce} \mathrm{NHylc} \mathrm{saturated}$ added, and $10 \mathrm{mg} \mathrm{Fo}$ carrier added. $\mathrm{x}_{2} \mathrm{CrO}_{4}$ solution is then added until complete preciritation. This precipitate is then washed with 18 $\mathrm{NH}_{4} \mathrm{Ac}$ until free from Cesium. If necessary, the proctpitate may be dissolved in 0.1 - N BCI and reprecipitated to free it from Cs.

(2) The Cs-rree $\mathrm{FoCrO}_{4}$ precipitate is then dissolved in I CC 0.1-N HCI and excess $\mathrm{H}_{2} \mathrm{~S}$ is bubbled in to precipitate black $\mathrm{FS}$ and reduce the $\mathrm{CrO}_{4}$ to $\mathrm{CrCl}_{3}$ (green).

(3) The solution from (2) contatning radiobariwn, is made alkalino, after botling to expel $\mathrm{kS} S$ and radioargons, and some $\mathrm{Fo}_{\mathrm{O}}(\mathrm{CI})_{3}$ added to help precipitate $\mathrm{Cr}(\mathrm{OH})_{3}$.

(4) The final, colorless solution has carrier-free barium. It is converted to the sulfate for mass spectrometer work. 
Remarks:

The cesium, being the target material, is very persistent, and several precipitations in stop ( 1 ) may be needed to free the bartum of $1 t$.

\section{PROCEDURE 9}

\section{BARIOM}

Source - R. H. Goeckermann in report AECD-2738 edited by W. W. Meinke, August 1949.

Target material: Approximately 1 g Bi motal

Type of bombardment: 184" all particles
Time for separation: 1-2 hrs.

Equipment requireds Centrifuge, tubes, ice, vacuum dessicator.

\section{Iield: Approximately $80 \%$}

Degree of purtfication: Decontamination factor approxinately $10^{4}$ from fission and spallation products. Be decontaminated approximately $10^{4}$ from Sr.

Advantages: Cood yield of Ba and Sr, separation from all other elements except

$\mathrm{Ba}$, very good separation of $\mathrm{Sr}$ and $\mathrm{Ba}$ from each other.

Procedure:

(1) To aliquot of $\mathrm{BNO}_{3}$ solution of target, add $10 \mathrm{mg} \mathrm{sr}$ and $\mathrm{Ba}, 30 \mathrm{ml}$ ruming $\mathrm{HNO}_{3}$, digest cold $1-2 \mathrm{~min}$.

(2) Dissolve precipitate in $2 \mathrm{ml} \mathrm{B}_{2} \mathrm{O}$ and reprecipitate with $15 \mathrm{ml}$ fuming $\mathrm{HNO}_{3}$.

(3) Dissolve prectpitate in 5-10 $\mathrm{ml} \mathrm{H}_{2} \mathrm{O}$, add $5 \mathrm{mg} \mathrm{Fe}^{+3}$, and precipttate $\mathrm{Fe}(\mathrm{OH})_{3}$ with tank $\mathrm{NH}_{3}\left(\mathrm{CO}_{3}=\text { free! }\right)^{2}$ Repeat $\mathrm{Fe}(\mathrm{OH})_{3}$ scavenge.

(4) Neutralize supernatant with $6 \mathrm{~N} \mathrm{HNO}_{3}$, add $1 \mathrm{ml} 6 \mathrm{HAc}$ and $2 \mathrm{ml}$ $6 \mathrm{M} \mathrm{NHilc}$. Heat to boiling and add $1 \mathrm{ml} 1.5 \mathrm{M} \mathrm{Na} 2 \mathrm{CrO}_{4}$ dropwise with stirring. Digest one min. (Save the supernatant for $\mathrm{Sr}$ fraction).

(5) $\mathrm{Ba}$ - Wash $\mathrm{BaCrO}_{4}$ precipitate with $10 \mathrm{ml}$ hot $\mathrm{H}_{2} \mathrm{O}$. Dissolve in $1 \mathrm{ml}$ $6 \mathrm{~N} \mathrm{HCl}$, add few $\mathrm{mg} \mathrm{Sr}$, and reprecioitate $\mathrm{BaCrO}_{4}$. Redissolve, add $15 \mathrm{ml}$ ether-HCl reagent (5 parts conc. $\mathrm{BCl}$ to 1 part di-ethyl ether), digest cold 2 min, wash with $5 \mathrm{ml}$ absolute EtOH containing a few drops of $\mathrm{HCl}$.

Dissolve $\mathrm{BaCl}_{2}$ in $1 \mathrm{ml} \mathrm{B}_{2} \mathrm{O}$, make just basic with $\mathrm{NH}_{3}$ and scavenge with $\mathrm{Fe}(\mathrm{OH})_{3}(5 \mathrm{mg})$. Add $15 \mathrm{ml}$ ether- $\mathrm{HCl}$ and reprecipitate $\mathrm{BaCl}_{2}$. Repeat if necessary. Filter last $\mathrm{BaCl}_{2}$ precipitate, wash three times with $5 \mathrm{ml}$ ether, dry in vacuum dessicator -2 min. evacuate release, $5 \mathrm{~min}$. evacuate. Weigh as $\mathrm{BaCl}_{2} \cdot 2 \mathrm{~F}_{2} \mathrm{O}(17.8 \mathrm{mg}$ per $10 \mathrm{mg} \mathrm{Ba}$ ).

Remarks: Procedure adapted for use when Sr activity much greater than Ba, Ra follows the $\mathrm{Ba}$ well, can be separated from it by use of a resin column. 


\section{PROCEDURE 10}

\section{BARIOM}

Source - H. Blcks, R. L. Folger, and R. H. Coockermann in report $\triangle B C D-2738$, odited by W. W. Kainke, Lugust 1949.

Target materiel: 0 or Th or Bi

Tim for separation: $30-45$ min.

Type of bombardment: Fission

Equipment required: ice bath

Iield: Approxtmately 100\%

Degree of purification: excellent

Mdvantages: Fast and easy

Procedure:

(1) Take aliquot of $\mathrm{HNO}_{3}$ or $\mathrm{BCl}$ solution of target and add Ba carrier. If necessary evaporate to less than 1 cc. With tube in ice bath, add $10 \mathrm{cc}$ ether -- BCI reagent (ether-BCI reagent - $400 \mathrm{cc}$ conc. BCI +80 ce diethyl-ether). Stir and digest 2 or 3 minutes to bring down sillky appearing $\mathrm{BaCl}_{2}{ }^{-2} \mathrm{~B}_{2} \mathrm{O}$.

(2) Centrifuge, dissolve in $0.5 \mathrm{ec} \mathrm{H}_{2} \mathrm{O}$, repeat (1).

(3) Centrifros, dissolve in $0.5 \mathrm{cc} \mathrm{H} 0$, dtlute to 7-8 cc, make to pH $>10$ with carbonate free ammonia and scarenge twice with $\mathrm{Fe}(\mathrm{OH})_{3} \cdot$

(4) Prectpitate $\mathrm{BaCO}_{3}$ by adding 3 drops saturated $\mathrm{Ha}_{2} \mathrm{CO}_{3}$, and digest 5 min. in hot water bath.

(5) Dissolve $\mathrm{BaCO}_{3}$ in $1 \mathrm{cc} 6 \mathrm{~N} \mathrm{HCl}$, repeat (1) and (2).

(6) Contrifuge, wash with 5 ce absolute alcohol, then 3 portions of $5 \mathrm{cc}$ other, weigh as $\mathrm{BaCl}_{2} \cdot 2 \mathrm{H}_{2} \mathrm{O}$.

Remarks: (2) can be modifled by adding double volume of ether saturated with $\mathrm{HCl}$ gas to $\mathrm{BaCl}_{2} \cdot 2 \mathrm{H}_{2} \mathrm{O}$ dissolved in $\mathrm{H}_{2} \mathrm{O}$ and continuing to introduce $\mathrm{HCl}$ gas until the crecipitate appears and the aqueous and organic layers become miscible.

PROCEDURB 11

BARIOM

Source - A. S. Wewton in report $\mathrm{ABCD}-2738$, edited by W. W. Woinlwe, lagust 1949.

Target material: Thorlum motal (.1-1 ga) Time for separation: $1 \mathrm{hr}$.

Type of bolbardmont: $60^{\circ}$ alphas Equipment roquireds Standard

Iield: Approximtely $60 \%$ on $\mathrm{Be}$

Degree of purifications $10^{6}$ other Mission Products approximately $10^{3}$ from Strontion. 
Advantages: Ba and Sr can be taken out in same procedure.

Procedure: The Th metal is dissolved in conc. HCl plus a few drops of , $M$ $\left(\mathrm{NH}_{4}\right)_{2} \mathrm{SiF}_{6}$ to clear up the black residue. The $\mathrm{HCl}$ is diluted to $2 \mathrm{~N}$ and an aliquot taken.

(1) Add $20 \mathrm{mg}$ each $\mathrm{Be}$ and $\mathrm{Sr}$ carrier and $30 \mathrm{ml}$ fuming nitric acid. Cool 1-2 minutes with stirring and centrifuge. (If $\mathrm{Sq}_{4}$ present add $\mathrm{H}_{2} \mathrm{SO}_{4}$ to precipitate $\mathrm{BaSO}_{4}$. Wash with $10 \mathrm{ml} \mathrm{H}_{2} \mathrm{O}$. Metathesize with $50 \% \mathrm{~K}_{2} \mathrm{CO}_{3}$ by boiling $5 \mathrm{~min}$. Centrifuge, wash with water, Dissolve precipitate in $\mathrm{I} \mathrm{N}^{\mathrm{N} \mathrm{N}_{3}}$. Discard residue. Then make fuming nitric acid precipitation.)

(2) Dissolve precipitate in $2 \mathrm{ml} \mathrm{H}_{2} \mathrm{O}$. Reprecipitate with $15 \mathrm{ml}$ fuming $\mathrm{HNO}_{3}$.

(3) Dissolve precipitate in 5 to $10 \mathrm{ml} \mathrm{H}_{2} \mathrm{O}$. Add $5 \mathrm{mg} \mathrm{Fe}$, precipitate $\mathrm{Fe}(\mathrm{OH})_{3}$ by adding $2 \mathrm{ml}$ carbonate free $6 \mathrm{M} \mathrm{NH}_{4} \mathrm{OH}$ or pass in $\mathrm{NH}_{3}$ gas to precipitate $\mathrm{Fe}(\mathrm{OH})_{3}$. Centrifuge.

(4) Neutralize supernate with $6 \mathrm{~N} \mathrm{HNO}$. Add $1 \mathrm{ml} 6 \mathrm{M} \mathrm{HAc}, 2 \mathrm{ml} 6 \mathrm{M}$ $\mathrm{NH}_{4} \mathrm{Ac}$. Heat solution to nearily boiling. Add $1 \overline{\mathrm{mll}}$ of $1.5 \mathrm{M} \mathrm{Na}_{\bar{C}} \mathrm{CrO}_{4}$ dropwise with stirring. Let stand 1 min. Centrifuge, Resêrve supernate for $\mathrm{Sr}$.

(5) Wash precipitate of $\mathrm{BaCrO}$ with $10 \mathrm{ml}$ hot $\mathrm{H}_{2} \mathrm{O}$. Dissolve in $1-2 \mathrm{ml}$

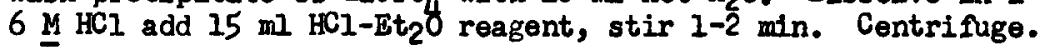

(6) Dissolve precipitate in $1 \mathrm{ml} \mathrm{H}_{2} \mathrm{O}$. Reprecipitate $\mathrm{BCl}_{2}$ with $15 \mathrm{ml}$ $\mathrm{HC} 1-\mathrm{Et}_{2} \mathrm{O}$ reagent. Centrifuge. Transfer precipitate to weighed filter paper with $4 \% \mathrm{KCl}$ in EtOH. Was h $3 \times 5 \mathrm{ml}$ EtO2. Dry by evacuation $2 \mathrm{~min}$, release, evacuate, $5 \mathrm{~min}$. Weigh as $\mathrm{KCl}_{2} \cdot \mathrm{H}_{2} \mathrm{O}$.

Remarks: This procedure has been described previously. (Phys. Rev. 7517 (1949).

\section{PROCEDURE 12}

BARIUM

Source - A. S. Newton in report $A E C D-2738$, edited by W. W. Meinke, August 1949.

Target meterial: Thorium metal $(.1-1 \mathrm{gm})$ Time for separation: $45 \mathrm{~min}$.

Type of bombardment: 60" alphas

Equipment required: Standard

Yield: $90 \%$

Degree of purification: $>10^{6}$ from all activities present

Procedure: The Th metal is dissolved in conc HCl plus a few drops of .2 M

$\left(\mathrm{NH}_{4}\right)_{2} \mathrm{SiF}_{6}$ solution to clear up the black residue. The $\mathrm{HCl}$ is diluted

to 2 N and an aliquot taken.

(1) 1-5 ml sample in $50 \mathrm{ml}$ centrifuge tube. Add $20 \mathrm{mg} \mathrm{Ba}$ carrier. If total volume is $>5 \mathrm{ml}$, boil down to $5 \mathrm{ml}$ or less. To cold solution add 30-35 ml HCl-ether reagent. Stir 1-2 min while 
PROchours 12 (Cont'd.)

cooling in 1ce bath. Centrifuge. Wash precipitate with 5 al BClEtro. Contrilsuge.

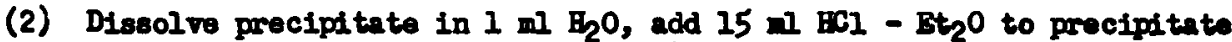
barlum. Centrifuge and wash with BCI - ethar solution.

(3) Repent (2).

(4) If scavenging is necessary diseolve in 4 ill $\mathrm{B}_{2} \mathrm{O}$, add 1-2 ag Fo th and Iresh (carbonate Iree) MH $\mathrm{OH}$ till an excess is present. Gentrifuge and discard precipitate. To soIution add 5 mI aCl-It 20 , cool and centrisuge.

(5) Dissolve precipltate in $\mathrm{H}_{2} \mathrm{O}$. Dilute to $10 \mathrm{ml}$, add 6 drope $\mathrm{ECl}$ เ $10 \mathrm{~g} \Delta \mathrm{g}$, digest, contri fuge off ${ }_{\mathrm{B}} \mathrm{Cl}$. Repest,

(6) Idd 1-2 mg Po , then $\mathrm{MH}_{4} \mathrm{OH}$. Hele 2 hydroxide precipitations of $\mathrm{Fe}(\mathrm{OH})_{3}$.

(7) Idd $\mathrm{K}_{2} \mathrm{CO}_{3}$, prectpitate $\mathrm{CCO}_{3}$. Dissolv in I il conc BCI, procipitate $\mathrm{BaCl}_{2}$ bo adding $\mathrm{BCl}$ - $\mathrm{Bt}_{2} \mathrm{O}$ reagent.

(8) Transfor precipltato to weighed IIIter with 3-5 wl partions of abeolute BtOH containing $4 \$ \mathrm{BCl}$. Filter with suction. Wash three timas with 5 il Bt 20 . Dry by evacuation. 2 min. orecuation, rolease, 5 min. evacuation. Weigh as $\mathrm{BaCl}_{2} \cdot \mathrm{B}_{2} \mathrm{O}$.

Remarles: This method has been described previcusly. (Furs. Rer. 7517 (1949)).

Preparation of carrier salutions Discolve $19.0 \mathrm{gm}\left(\mathrm{HO}_{3}\right)_{2}$ in water and dilute to 1 iiter.

Stendardization as $\mathrm{BaCl}_{2} \cdot \mathrm{H}_{2} \mathrm{O}$ : Take $5 \mathrm{ml}$ carrier, add 50 al otbor- $\mathrm{ECl}$ dxture. Cool In Ice bath for 10 mintes. Stir, filter onto a sintered glass crucible. Uee 3 - 5 ml portions of absolute BtOH containing 3-5 drops conc BCI to transfer and wash the precipitate. Whes with throe 5 II portions of $\mathrm{Bt}_{2} \mathrm{O}$. Bracuate and weigh as $\mathrm{BCCl}_{2} \cdot \mathrm{B}_{2} \mathrm{O}$.

\section{FROCEDURE 13}

BARIUN

Source - I. E. Glendenin, Paper 288 in "Radiochorical Studies The

Fission Products", edited by C. D. Coryell and N. Sugarman, ModrewHill Book Co., Inc., New York, 1951. It is based on repart $\mathrm{CN}-1312$, dated Yay 15, 1945.

\section{INTRODUCTION}

The specific preclpitation of $\mathrm{BCl}_{2}$ by conc. $\mathrm{HCl}$ is the classical mothod for the isolation of bariun from fis sion-product mixtures. 65 The notbod 66 previously employed on the Project consisted in three precipitations of barium as $\mathrm{BaCl}_{2} \cdot \mathrm{H}_{2} \mathrm{O}$, a $\mathrm{Ia}(\mathrm{OH})_{3}$ scavenging precipitate, and a final precipitation 


\section{PROCGDORT 13 (Cont'd.)}

of barium as BaCrO 4 . I mixture of BCl and ether has also been used to precipitate $\mathrm{BCI}_{2}$, since the precipitation by this reagent is more complete than the precipitation by HCl alone. 67,68 The solubility is less than 1 part in 120,000 .

In the search for a mothod applicable to all types of flssion-product solutions, a more rapid mothod of analysis has been developed which consists aimply in a triple precipitation of $\mathrm{BaCl}_{2} \cdot \mathrm{H}_{2} \mathrm{O}$ by a $\mathrm{BCl}$-ether inture (5 parts of conc. HCl to 1 part of ethyl other) and weighing as such after alcohol-ether washing and racuun desiccation. The improved procedure is given below. Further testing of the procedure for special applications has been done by Nelson, Boldridge, and Hume.69

\section{PREPARATION AND STANDARDIZATION OF CARRTER}

Dissolve $19.0 \mathrm{~g}$ of $\mathrm{Ba}\left(\mathrm{NO}_{3}\right)_{2}$ in $\mathrm{H}_{2} \mathrm{O}$ and dilute to 1 liter.

Standardization as $\mathrm{BaCl}_{2} \cdot \mathrm{H}_{2} \mathrm{O}$ : Pipat $5 \mathrm{ml}$ of carrier solution into a beaker and add $50 \mathrm{ml}$ of HCl-ether mixture ( 5 parts of conc. HCl to 1 part of ethyl ether). Cool in an ice bath for about 10 min with occasional stirring. Filter quantitatively on a weighed sintered-glass crucible with suction, transferring and washing with three 5-ml portions of absolute ethanol containing 4 per cent conc. HCI. Wash three times with 5 ml of ether, rinsing down the inside of the crucible with each washing. Wipe the outside of the crucible carefully with Kleenex or a lintless cloth, and place in a vacuum desiccator. Evacuate for 2 min., release the suction, and evacuate again for 5 min. Weigh as $\mathrm{BCl}_{2} \bullet \mathrm{H}_{2} \mathrm{O}$ and repeat the desiccation until the wight is constant to $0.2 \mathrm{mg}$.

\section{PROCEDURE}

Step 1. Take 1 to $5 \mathrm{ml}$ of a sample of fission material (Note 1 ) in a 50-ml centrifuge tube and add $2 \mathrm{ml}$ of standardized barium carrier. If the total volume exceeds $5 \mathrm{ml}$, boil down to $5 \mathrm{ml}$ or less. Add 30 to $35 \mathrm{ml}$ of $\mathrm{HCl}$-ether reagent to the cool solution, and stir for 1 to 2 min while cooling under running tap water. Centrifuge, decant completely, wash with 


\section{PROCKDORT 13 (Cont'd.)}

5 ml of HCl-ether mixture, centrifuge, and again decant completaly.

Step 2. Dissolve the precipitate in $1 \mathrm{ml}$ of $\mathrm{H}_{2} \mathrm{O}$ and reprecipitate with $15 \mathrm{ml}$ of HCl-ether mixture. Centrifuge and decant.

Step 3. Repeat the precipitation, centriflge, and decant thoroughly. Note the time.

Step 4. Transfor the precipitate to a weighed filtar-peper disk (Note 2) in a smoll Hirsch fumel with three 5-mil portions of 4 per cont BCl in ethanol (Note 3). Filter with suction. Wash three times with 5-mil portions of ether and suck dry. Trans fer the paper with the precipitate to a small watch glass, and place in a vacuum desiccator. Bvacuate for 2 min, release the suction, and then evacuate again for 5 min. Weigh the precipitate as $\mathrm{BaCl}_{2} \cdot \mathrm{H}_{2} \mathrm{O}$ and mount for counting (Note 4). For samples of higher purity than those obtained in this procedure, a $\mathrm{Fe}(\mathrm{OH})_{3}$ scarenging precipitation can be performed (Note 5).

Notes. 1. The solution taken for analysis should be free of acidInsoluble residue, since any solid meterial present will be weighed with the $\mathrm{BCCl}_{2} \cdot \mathrm{H}_{2} \mathrm{O}$. The sample should be filtered or put into solution if it is not perfectly clear, provided it does not contain $\mathrm{SO}_{4}^{-}$. For samples containing $\mathrm{SO}_{4}^{--}$proceed as follows: Add $2 \mathrm{ml}$ of standardized barium carrier (ignoring any precipitate formed), dilute to $10 \mathrm{ml}$, and add $2 \mathrm{ml}$ of $6 \mathrm{~N} \mathrm{H}_{2} \mathrm{Sq}_{4}$. Heat and stir for 1 to $2 \mathrm{~min}$, centrifuge, and wash with $10 \mathrm{ml}$ of $\mathrm{H}_{2} \mathrm{O}$. Comrert the $\mathrm{EaSO}_{4}$ to $\mathrm{BaCO}_{3}$ by boiling with $10 \mathrm{ml}$ of 50 per cent $\mathrm{K}_{2} \mathrm{CO}_{3}$ for 5 min, centrifuge, and wash with $10 \mathrm{ml}$ of $\mathrm{H}_{2} \mathrm{O}$. Dissolve the precipitate of $\mathrm{BaCO}_{3}$ in a little $6 \mathrm{M} \mathrm{HCl}$, centrifuge or filter out ang precipitate present, and proceed with the boiling in step 1.

2. The filter-paper disk must be washed with ethanol and ether and must be dried under the sam conditions as in the procedure before the waighing.

3. Barium chloride is apprecinbly soluble in abeolute ethanol. The presence of the HCl represses the solubility and allows a quantitative recorery. 
PROCEDURS 13 (Cont'd.)

4. The $\beta$-activity measurement of the berium semple should be taken as soon as possible after the last precipitationg this is considered sero time for the lanthanum daughter growth. The growth of Iallio activity is nearly linear with time at the beginning, and the observed $\rho$ activity of the En 140 can be corrected to zero $L^{140}$ grourth by the relation $\Lambda_{0}=A_{t} /(1+0.0151 t)$, where $\Lambda_{0}$ is the original activity and $\Lambda_{t}$ is the activity arter $t$ hr. This expression is weld for about the first 10 or $12 \mathrm{hr}$ of growth.

Alternatively the sample cen be set aside to allon the LOh Iall daughter to grow and its $Y$ radistion to be measured. The maximum Iallo activity is attained at $134 \mathrm{hr}$ after separation, and the measurement should be made at this tim. I discussion of the growth of $\mathcal{\beta}$ activity in Bllo as affected by absorption is given elsewhere?

5. The rapid procedure provides a decontamination factor of about $10^{3}$ from other fission activities. In special cases where greater purity may be desired, the following procedure should be used: Dissolve the $\mathrm{BCl}_{2} \cdot \mathrm{H}_{2} \mathrm{O}$ from step $I$ in $5 \mathrm{ml}$ of $\mathrm{H}_{2} \mathrm{O}$, and add 1 to $2 \mathrm{mg}$ of $\mathrm{Fe}^{+3}$ carrier. Heat nearly to boiling and add $1 \mathrm{ml}$ of $6 \mathrm{M} \mathrm{MH}_{4} \mathrm{OH}\left(\mathrm{CO}_{2}-\mathrm{fres}\right)$. Centrifuge, and discard the precipitate of $\mathrm{Fe}(\mathrm{OH})_{3}$. Repreclpitate the $\mathrm{BCCl}_{2} \cdot \mathrm{H}_{2} \mathrm{O}$ from the supernatent solution with 34 ml of HCl-ether nixture, centrifluge, and proceed with step 3.

The addition of the $\mathrm{Fe}(\mathrm{OH})_{3}$ scavenging step increases decontamination considerably and requires little extra time.

\section{DISCUSSION}

In standardization of the carrier the presence of a small amount of $\mathrm{HCl}$ ( 3 to 5 per cent) in the ethanol wash was found necessary to prevent the loss of barium in this step. There is no loss in the HCl-ethar precipitation or in the ether wash. $\Delta l 1$ the filtrates and washings in the standardization procedure gave nigative tests for barium on the addition of $\mathrm{H}_{2} \mathrm{SO}_{4}$, whereas the presence of as little as 0.5 mg of barium gave a distinct precipitate.

The composition of the $\mathrm{BCl}_{2}$ precipitate was determined by standardizing a barium carrier solution that had also been standardized as BerO4. For $5 \mathrm{ml}$ 
PROCADUE 13 (Cont'd.)

of salution, $93.2 \mathrm{mg}$ of $\mathrm{BCrO}_{4}$ was obtulined; this is equivalent to $50.6 \mathrm{mg}$ of barime or $83.2 \mathrm{mg}$ of $\mathrm{BaCl}_{2} \cdot \mathrm{H}_{2} \mathrm{O}$. Standardisation of the carrier solution in triplicate by the method described here gave $\mathrm{BnCl}_{2}$ precipitates with an average waght of $83.2 \mathrm{mg}$ and with a man doviation of 0.8 par cent.

\section{PROCEDURE 14}

GAICIOH

Source - W. H. Eurgus in "Collected Radiochenical Procedures", Los Alamos report IA-1721. Jan. 1958.

This procedure is an adaption by W. H. Burgus of one previcusly reported by E. P. Steinberg in Radiochemical Studies: The Fission Products, Book 1, MoGraw-Hi11, New York, 1951, p. 482.

\section{Introduction}

Calcium is first separeted from most of the fission products by appropriate ferric hodroxide, acid sulfide, and amonium sulfide scavenging steps. This is followed by separation of calcium, strontiun, and barium as oxalates. The oxalates are then dissolved, and strontiun and barium are removed quantitatively by precipitation of their nitrates from fuming nitric acid. The $40 \mathrm{~h} \mathrm{La} 140$, which has grown in from $12.5 \mathrm{~d} \mathrm{Bn}^{240}$ during the interval between the rerric bydroxide scavenging step and the last separation of barium and strontium from calcium, is separated by means of lanthanum hydroxide scavenger. Calcium is finally precipitated as calcium oxalate monohydrate, $\mathrm{CaC}_{2} \mathrm{O}_{4} \cdot \mathrm{H}_{2} \mathrm{O}$, and counted in this form. The chemical yield appraximates $30 \%$, and the time for a single analysis is about $1-3 / 4$ hours.

\section{Reegents}

Ca carrier: $10 \mathrm{mg} \mathrm{Ca} / \mathrm{ml}$ (added as $\mathrm{Ca}\left(\mathrm{NO}_{3}\right)_{2} \cdot 4 \mathrm{H}_{2} \mathrm{O}$ in very dilute $\mathrm{HrO}_{3}$ ) -standardized

Fe carrier: $10 \mathrm{mg} \mathrm{Fe} / \mathrm{ml}$ (added as $\mathrm{FeCl}_{3} \cdot 6 \mathrm{H}_{2} \mathrm{O}$ in very dilute $\mathrm{HCl}$ )

Pd carrier: $10 \mathrm{mg} \mathrm{Pd} / \mathrm{ml}$ (added as $\mathrm{PdCl}_{2} \cdot 2 \mathrm{H}_{2} \mathrm{O}$ in very dilute $\mathrm{HCl}$ ) Cu carrier: $10 \mathrm{mg} \mathrm{Cu} / \mathrm{ml}$ (added as $\mathrm{CuCl}_{2} \cdot 2 \mathrm{H}_{2} \mathrm{O}$ in $\mathrm{H}_{2} \mathrm{O}$ ) 
$\mathrm{Ni}$ carrier: $10 \mathrm{mg} \mathrm{Ni} / \mathrm{ml}$ (added as $\mathrm{Ni}\left(\mathrm{NO}_{3}\right)_{2} \cdot 6 \mathrm{H}_{2} \mathrm{O}$ in very dilute $\mathrm{ENO}_{3}$ )

Co carrier: $10 \mathrm{mg} \mathrm{Co} / \mathrm{ml}$ (added as $\mathrm{Co}\left(\mathrm{NO}_{3}\right)_{2} \cdot 6 \mathrm{H}_{2} \mathrm{O}$ in very dilute $\mathrm{HNO}_{3}$ )

Sr carrier: $10 \mathrm{mg} \mathrm{Sr} / \mathrm{ml}$ (added as $\mathrm{Sr}\left(\mathrm{NO}_{3}\right)_{2} \cdot 4 \mathrm{H}_{2} \mathrm{O}$ in very dilute $\mathrm{HNO}_{3}$ )

ba carrier: $10 \mathrm{mg} \mathrm{Ba} / \mathrm{ml}$ (added as $\mathrm{Ba}\left(\mathrm{NO}_{3}\right)_{2}$ in $\mathrm{H}_{2} \mathrm{O}$ )

La carrier: $10 \mathrm{mg} \mathrm{La} / \mathrm{ml}$ (added as $\mathrm{La}\left(\mathrm{NO}_{3}\right)_{3} \cdot 6 \mathrm{H}_{2} \mathrm{O}$ in $\mathrm{H}_{2} \mathrm{O}$ )

$\mathrm{HCI}: 6 \mathrm{M}$

$\mathrm{HNO}_{3}$ : conc.

$\mathrm{HNO}_{3}$ : white fruming

$\mathrm{NH}_{4} \mathrm{OH}$ : conc.

$\left(\mathrm{NH}_{4}\right)_{2} \mathrm{CO}_{3}$ : saturated aqueous solution

$\left(\mathrm{NH}_{4}\right)_{2} \mathrm{C}_{2} \mathrm{O}_{4}: 4 \%$ aqueous solution

$\mathrm{NaBrO} \mathrm{H}_{3}: \quad \underline{M}$

$\mathrm{H}_{2} \mathrm{~S}$ : gas

Ethanol: 95\%

\section{Equipment}

Drying oven

Centrifuge

Fisher burner

Block for holding centrifuge tubes

Forceps

Mounting plates

Tongs for holding Erlenmeyer flasks

Ground-off Hirsch funnels: Coors 000A (one per sample)

Filter chimney (ona per sample)

Filter flask (one per sample)

Fipets: $2-\mathrm{ml}$

Wash bottle

125-ml Erlenmeyer flasks (three per sample)

2", 60* short stem glass funnels (two per sample)

40-ml conical centrifuge tubes: Pyrex 8320 (1l per sample) 
PEOCADUEA 14 (Cont'd.)

100 -al beakers (one per standardization)

15-al sintered glass Gooch crucibles? fine porosity (one per standardization)

Filter flasks and holders for Gooch cricibles (one each per standardization)

No. 40 Whatmen filter paper $(9 \mathrm{~cm})$

No. 42 Watman filter peper (tared for mounting): 7/8" diamater

Stirring rods

Ice bath.

4. Preparation and Standerdization of Carrior

Dissolve 59.0 of $\mathrm{Ca}\left(\mathrm{HO}_{3}\right)_{2} \cdot 4 \mathrm{H}_{2} \mathrm{O}$ in $\mathrm{H}_{2} \mathrm{O}$, add 2 mil of $\mathrm{HlO}_{3}$, and dilute to 1 liter with $\mathrm{H}_{2} \mathrm{O}$.

Pipet a 2-ml aliquot of the above cerrier solution into a 100-nl beaker, dilute to $50 \mathrm{ml}$, heat to boiling, and precipitate $\mathrm{CaC}_{2} \mathrm{O}_{4} \cdot \mathrm{H}_{2} \mathrm{O}$ by the addition of a slight axcess of $4 \%$ ( $\left.\mathrm{NH}_{4}\right)_{2} \mathrm{C}_{2} \mathrm{O}_{4}$ solution. Filtar onto a tared sintered glass Gooch crucible (fine porosity). Wash throe times with 10-ml portions of hot $\mathrm{H}_{2} \mathrm{O}$ and once with ethanol. Suck dry for several mimites. Dry to constant weight in oven at no more than $100^{\circ}$.

Four standardizations are performed. The results should agreo wit thin $0.5 \%$.

\section{Procedure}

Step 1. To the sample in a $40-\mathrm{ml}$ centrifige trbe, add sufflcient $\mathrm{H}_{2} \mathrm{O}$ to bring the volume to 15 to $20 \mathrm{ml}$, then add $2 \mathrm{ml}$ of standard $\mathrm{Ca}$ carrier. If $U$ is present, heat the solution to bolling and by the dropwise addition of conc. $\mathrm{NH}_{4} \mathrm{OH}$ precipitate ammonium diuranate. Centrifuge and discard the precipitate, transforring the supernate to a $40-\mathrm{m}$ centrifuga tabe. If no appreciable quantito of $\mathrm{J}$ is present, proceed imediately to Step 2.

Step 2. Lcidify the solution with conc. $\mathrm{HNO}_{3}$, add 6 dropo of To carrier, heat to bolling, and by the dropwise addition of conc. $\mathrm{NH}_{4} \mathrm{OH}$ precipitate $\mathrm{Fe}(\mathrm{OH})_{3}$. Centrifuge and discard the precipitate, transferring the supernate to a 40-ml centrifluge tube. 
Proctroue 14 (Cont'd.)

Step 3. Repeat Stop 2.

Step 4. Repeat Step 2 again.

Step 5. Wake the supernate, after the $\mathrm{Fe}(\mathrm{OH})_{3}$ scavenging operatica, $0.1 \mathrm{I}$ in $\mathrm{HCl}$, and add 4 drops of Pd and 8 drops of $\mathrm{Cu}$ carriers. Heat to boiling and pass in $\mathrm{H}_{2} \mathrm{~S}$ for 4 to 5 min. Filter the acid sulfide scarenging precipitate on a No. 40 Whatman paper and discard it, catching the filtrate in a 40-ml contriflage tube.

Step 6. Idd 4 drope each of $\mathrm{NI}$ and Co carriers to the piltrate and heat to boiling. Idd conc. $\mathrm{NH}_{4}$ OH until the solution is besic to Iitwers, then add an additional $0.5 \mathrm{ml}$ of $\mathrm{NH}_{4} \mathrm{OH}$. Pass in $\mathrm{H}_{2} \mathrm{~S}$ for 3 win and filter the ammonium sulfide scavenge on a No. 40 Whatman paper, catching the filtrate in a $40-\mathrm{ml}$ centrifuge tube. Discard the precipitate.

Step 7. Idd 3 mil of $4 \%\left(\mathrm{MH}_{4}\right)_{2} \mathrm{C}_{2} \mathrm{O}_{4}$ solution to the filltrate fram above. Centrifuge and discard the supernate. Wash the precipitate with $30 \mathrm{mI}$ of $\mathrm{H}_{2} \mathrm{O}$.

Step 8. Dissolve the precipl tate in $5 \mathrm{ml}$ of $\mathrm{H}_{2} \mathrm{O}$ and $1 \mathrm{ml}$ of conc. $\mathrm{HNO}_{3}$. Idd I ml each of and $\mathrm{Sr}$ scavengers. Precipitate $\mathrm{Br}\left(\mathrm{NO}_{3}\right)_{2}$ and $\mathrm{Sr}\left(\mathrm{NO}_{3}\right)_{2}$ by the addition of $30 \mathrm{ml}$ of white fuming $\mathrm{HNO}_{3}$. CoOl in an ice bath for several minutes. Centrifuge and discard the precipitate, transferring the supernate to a 125-ml Erlermegrer flask.

Step 9. Boil down the Ca-containing supernate to a volume of 1 to $2 \mathrm{ml}$. Add $5 \mathrm{ml}$ of $\mathrm{H}_{2} \mathrm{O}, \mathrm{I} \mathrm{ml} \mathrm{eech} \mathrm{of} \mathrm{Ba}$ and $\mathrm{Sr}$ carriers, and $30 \mathrm{ml}$ of fuming $\mathrm{ENO}_{3}$ to precipitate $\mathrm{Ba}\left(\mathrm{NO}_{3}\right)_{2}$ and $\mathrm{Ca}\left(\mathrm{NO}_{3}\right)_{2}$. Cool and trans fer the mixture to a 40-ml centrifuge tube. Centrifuge, transfer the supernate to a $125-\mathrm{ml}$ Frlemeyer flask, and discard the precipitate.

Step 10. Repeat Step 9.

Step 11. Boil down the supernate to 2 to $3 \mathrm{ml}$ and add $30 \mathrm{ml}$ of $\mathrm{H}_{2} \mathrm{O}$. Transier to a 40-ml centrifuge tube and make ammoniacal with conc. NA 4 OH. Idd $2 \mathrm{ml}$ of $4 \%\left(\mathrm{NH}_{4}\right)_{2} \mathrm{C}_{2} \mathrm{O}_{4}$ solution to insure complete precipitation of $\mathrm{CaC}_{2} \mathrm{O}_{4} \cdot \mathrm{H}_{2} \mathrm{O}$. Centrifuge and discard the supernate. 


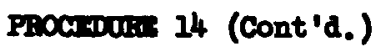

Step 12. Dissolve the $\mathrm{CaC}_{2} \mathrm{O}_{4} \cdot \mathrm{H}_{2} \mathrm{O}$ in 2 all of conc. Hin 3 and 2 al

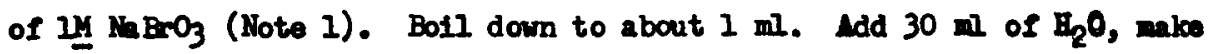
strongly amoniacel, and add 4 ml of saturated $\left(\mathrm{xH}_{4}\right)_{2} \mathrm{CO}_{3}$ solution. Contriflese the $\mathrm{CaCO}_{3}$ and discard the supernate.

Step 13. Diseolve the $\mathrm{CaCO}_{3}$ in 1 to 2 il of Conc. $\mathrm{HWO}_{3}$. Dillute to $30 \mathrm{~m}$, and add $1 \mathrm{ml}$ of Le carrier. Precipitate $\mathrm{Ia}(\mathrm{OH})_{3}$ the addition of conc. $\mathrm{NH}_{4} \mathrm{OH}$. Centrifluge, transfer the supermate to a 40-ml contrifluge tube, and discard the precipitate.

Step 14. Heat the supernate to bolling anf precipitate $\mathrm{CaC}_{2} \mathrm{O}_{4} \cdot \mathrm{H}_{2} \mathrm{O}$ by the dropuise addition of $3 \mathrm{ml}$ of $4 \%\left(\mathrm{NH}_{4}\right)_{2} \mathrm{C}_{2} \mathrm{O}_{4}$. Filter the $\mathrm{CaC}_{2} \mathrm{O}_{4} \cdot \mathrm{H}_{2} \mathrm{O}$ on a tared whatman $\mathrm{H}_{0} 42$ circle, using a ground-off Birsch funmel and a chimey. Wash three tines with 10-mil portions of hot $\mathrm{B}_{2} \mathrm{O}$, and then with ethanol. Suck dry. Dry in oven at $100^{\circ}$ for 5 min. Weigh, mount, and count (Note 2).

\section{Notea}

1. $\mathrm{NaErO}_{3}$ is used to destroy oxalate and thus avold precipitation of lanthamen oxalate when the La carrier is added (Step 13).

2. No specigl preceutions noed be taken in counting. If shortlived isotopes are present, the decay curve must be resolved. If $150 \mathrm{~d}$ $C_{2} 45$ is to be counted, the chemistry employed for separation of $\mathrm{Ca}$ is carried out after the decay of the short-lived isotopes.

\section{PROCEDURE 15}

CAICIOM

Source - D. Stewart and S. Softky in report AECD-2738, edited by W. W. Neinke, August 1949.

Target material: Copper (up to $10 \mathrm{~g}$ )

Type of bombardment: Neutrons 184*
Time for separation: $4 \mathrm{hrs}$.

Equipment required: $200 \mathrm{ml}$ stainless steel beaker Pt stirrer electrode

D. C. source $200 \mathrm{ml}$ centrifuge cone 
Yleld: $60-80 \%$

Degree of purtfication: $10^{6}$ from ou

Procedure:

(1) Dissolve $\mathrm{Cu}$ in minimum dilute $\mathrm{HNO}_{3}$ in a stainless steel beaker, add $10 \mathrm{mg} \mathrm{Ca}$ carrier as nitrate and 2-3 drops of conc. $\mathrm{H}_{2} \mathrm{SO}_{4}$. Dilute to 100-150 ml.

(2) Electrodeposit copper at 2-3 volts using the beaker as the cathode and a rotating platinum anode. Keep the stainless steel beaker in an ice bath during the electrolysis.

(3) When solution is water-white remove the anode and transfer the solution quickly to a $200 \mathrm{mI}$ centrifuge cone. Neutralize with $\mathrm{NH}_{4} \mathrm{OH}$ and make just acid with $\mathrm{HNO}_{3}$. Worm in a hot water bath.

(4) Add $20 \mathrm{~g}$ crystalline ammonium oxalate and stir solution for 30 minutes, keeping it warm. Transfer to an ice bath and continue stirring for another 30 minutes.

(5) Let settle, and finally centrifuge. Pipet off the supernatant. Wash $\mathrm{CaC}_{2} \mathrm{O}_{4}$ with hot water containing a little $\left(\mathrm{NH}_{4}\right)_{2} \mathrm{C}_{2} \mathrm{O}_{4}$ until wash solution is colorless.

\section{PROCEDURE 16}

\section{CAICIUM}

Source - R. E. Batzel in report AECD-2738, edited by $N$. W. Neinike, August 1949.

Target material: cooper

Time for separation - $45 \mathrm{~min}$.

Type of bombardment: AII 60" and 184" Equipment required: standard

Yield: $95 \%$

Degree of purificztion: $10^{3}$

Advantages: Pure fraction with good yield.

Frocedure:

(1) Dissolve the copper in the minimum amount of concentrated $\mathrm{:HO}_{3}$ : Add few mg carriers ( $\mathrm{Zn}$ and below) including $\mathrm{Ca}$ and make the solution ammonical with carbonate free $\mathrm{NH}_{4} \mathrm{OH}$.

(2) Precipitate the sulfides with $\mathrm{H}_{2} \mathrm{~S}$. Add holdback carriers and scavenge yith another sulfide precipitation. Repeat.

(3) Boil to remove the $\mathrm{H}_{2} \mathrm{~S}$ and make acid with oxalic acid . Add $5 \mathrm{mI}$ of $48\left(\mathrm{NH}_{4}\right) \mathrm{C}_{2} \mathrm{O}_{4}$ and allow precinitate to settle for 10 minutes in a steam bath.

(4) Wash the precipitate with water containing oxalic acid and amonium oxalate. 


\section{PROC.sDure 16 (Cont'd.)}

(5) Dissolve the precipitate in $6 \mathrm{~N} \mathrm{HNO}_{3}$ and add a crystal of $\mathrm{KClO}_{3}$ to remove oxalate Lons.

(6) alke amonical and scavenge 2 times with $\mathrm{Fe}(\mathrm{OH})_{3}$.

(7) Kake acid wth oxalic acid and add 3 ce of $48\left(\mathrm{NH}_{4}\right)_{2} \mathrm{C}_{2} \mathrm{O}_{4}$. NIIO to settle for 10 minutes on a steam bath.

(8) Centrifuge, wash, filter, and dry at $100 \mathrm{C}$. The precipitate is weighed as $\mathrm{CaC}_{2} \mathrm{O}_{4} \cdot \mathrm{H}_{2} \mathrm{O}$.

Remarks:

(1) See Scott's Standard Nethods of Chemical Analysis, Page 210-211. Vol. I, Fifth Edition, 1939.

\section{PROCEDURE 17}

\section{GALCTOS}

Source - R. H. Goeckermam in report $A S C D-2738$, odited by W. W. Meinke, August 1949.

Target material: Apcroxinetely 1 g Bi metal Time for separation: Fow hrs.

Type of bombardment: 184" bombardment all particles

Equipment required: Centrifuge

Yield: Approximately 20;

Degree of purification: $30 \mathrm{c} / \mathrm{m}$ of $\mathrm{Ca}$ separated from aporoximately a millicurie of fission and spallation nroducts.

Adventages: Separates $\mathrm{Ca}$ from all other elements.

Procedure:

(1) To alianot of $\mathrm{HNO}_{3}$ solution of $\mathrm{BI}$, add $20 \mathrm{mg} \mathrm{Ca}$ and $10 \mathrm{mg}$ each of $\mathrm{Ru}, \mathrm{Cb}, \mathrm{Fe}, \& \mathrm{La}$. Nake $0.5 \mathrm{~N}$ in $\mathrm{HCl} \&$ precipitate with $\mathrm{H}_{2} \mathrm{~S}$.

(2) Add $10 \mathrm{mg} \mathrm{Ru}$ and $\mathrm{BI}$ to supernatant and repeat $\mathrm{H}_{2} \mathrm{~S}$ precipitation.

(3) Botl out $\mathrm{H}_{2} \mathrm{~S}$ and precipitate with $\mathrm{NH}_{3}$.

(4) Add $10 \mathrm{mg} F e$ and $\mathrm{Y}$ to supernatant and reveat $\mathrm{NH}_{3}$ precipitation.

(5) Boil down to approximately $5 \mathrm{ml}$, add $10 \mathrm{mg} \mathrm{Ba}$ and $\mathrm{Sr}$, and precipitate with cold fuming $\mathrm{HNO}_{3}$.

(6) Add more $\mathrm{Sr}$ and $\mathrm{Ba}$ to supernatant and repeat orectoitation three times.

(7) Add or alone and repeat two times more.

(8) Boil down to approximately $5 \mathrm{ml}$, add $5 \mathrm{ml}$ saturated $\left(\mathrm{NH}_{4}\right)_{2} \mathrm{C}_{2} \mathrm{O}_{4}$. and make basic with $\mathrm{NH}_{3}$. 


\section{PROGADUR 27 (Cont'd.)}

(9) Dissolve $\mathrm{CaC}_{2} \mathrm{O}_{4}$ precipitate in $\mathrm{HNO}_{3}$, destroy $\mathrm{C}_{2} \mathrm{O}_{4}=$ with $\mathrm{KClO}_{3}$. and make basic with $\mathrm{NH}_{3}$. Add $\mathrm{Fe}, \mathrm{ta}$, and $\mathrm{Y}$, centrifuge.

(10) Add more $F e, I_{a}$, and $Y$ to supernatant and repeat precipitation, centrifuge.

(II) Repeat step (5).

(12) Boil supernatant down to aporoximately $5 \mathrm{ml}$, make basic with $\mathrm{NH}_{3}$, heat, add $5 \mathrm{mI}$ saturated $\left(\mathrm{NH}_{4}\right)_{2} \mathrm{C}_{2} \mathrm{O}_{4}$ slowly. Stir 2 min, filter. wash three times with $5 \mathrm{mI} \mathrm{B} \mathrm{O}^{2}$, three times with $5 \mathrm{ml} 95 \% \mathrm{EtOH}$, three times with $5 \mathrm{ml}$ ether. Dry in vacuum desiocator $-2 \mathrm{~min}$. evacuation, release, $5 \mathrm{mtn}$. evacuation. Weigh as $\mathrm{CaC}_{2} . \mathrm{O}_{4}$ (32 mg per $10 \mathrm{mg} \mathrm{Ca}$ ). 
PROCETUUR 18

\section{CALCIIM}

Source - Abraham Eroido in U. S. Atoude Enerey Commiseion Report ISCD-2616, JulJ, 1947.

APPLIGATION OF THENOYL TRIFLUORMCETONG (TTA) EXTRACTION TO THE PREPARATION OF Ca45

This report presents the development of a satis factory mothod for the preparation of cerrier-free $\mathrm{Ca}^{45}$ trom bombarded scandiun besed on the use of the chelating agent TTA. The following general flow weet was ueed to prepare several samples of carrier-freo Ca 45 from scandium.

\begin{tabular}{|c|c|c|c|c|c|}
\hline $\begin{array}{l}\text { Irradiated } \\
\mathrm{Se}_{2} \mathrm{O}_{3} \\
\text { (1) }\end{array}$ & \multicolumn{5}{|c|}{ 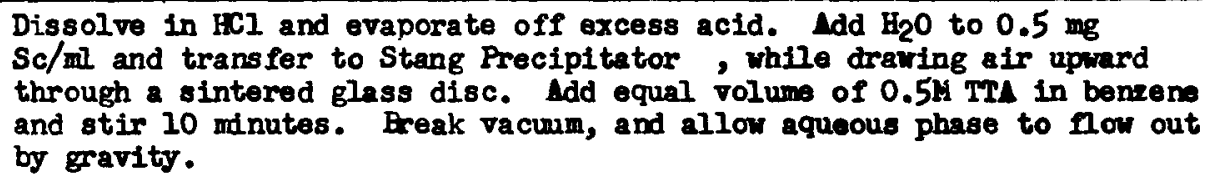 } \\
\hline \multirow{4}{*}{$\begin{array}{l}\text { (2) Benzene } \\
\text { phase: } \\
\text { Contains } \\
\text { Sc and more } \\
\text { extractable } \\
\text { cations } \\
\text { (Note 1) }\end{array}$} & \multicolumn{5}{|c|}{$\begin{array}{l}\text { (3) Aqueous phase: Contains Ca45 and all salto not extractable } \\
\text { at pH } 1.5 \text {. Add NaOH to final pH } 5 \text { and extract with } 0.5 \mathrm{M} \\
\text { TTL in benzene. }\end{array}$} \\
\hline & \multirow{3}{*}{$\begin{array}{l}\text { (4) Benzene phases } \\
\text { Contains Sc and } \\
\text { all cations } \\
\text { extracteble be- } \\
\text { tween pH } 1 \text { and } \\
\text { pH } 5 \text {. }\end{array}$} & \multicolumn{4}{|c|}{$\begin{array}{l}\text { (5) Aqueous phase: Contains Cath, } \\
\text { anions, alkeli motals. Add } 0.5 \mathrm{~K} \\
\text { TTL in bensene; add NaOH to neu- } \\
\text { tralles } 90 \% \text { of TT; IImel pH }=8.2 \text {. }\end{array}$} \\
\hline & & $\begin{array}{l}\text { (6) Bensene } \\
\text { (Note 2) } \\
\text { Add wate } \\
\text { (Note 4) }\end{array}$ & ase: $\mathrm{Ca}_{4} 45$ & (7) & $\begin{array}{l}\text { Iqueous } \\
\text { phase: } \\
\text { inions, } \\
\text { alkal1 } \\
\text { motels, } \\
\text { etc. }\end{array}$ \\
\hline & & $\begin{array}{l}\text { (8) Benzene } \\
\text { phase: } \\
\text { (Discard) } \\
\text { (Note 3) }\end{array}$ & $\begin{array}{l}\text { (9) Aqueous } \\
\text { phase: } \\
\text { (Ca45 prep) } \\
\text { (Note 5) }\end{array}$ & & $\begin{array}{l}\text { (Discard) } \\
\text { (Note 3) }\end{array}$ \\
\hline
\end{tabular}

Notes :

(1) As a check on possible calcium loss bere, calcium carrier was added and the extraction fepeated. The quantitatively recorered calcium carrier contained no $\mathrm{Ca}^{45}$ activity.

(2) Up to this point the benzene phases pay be washed with vater. Washing with water here will extract the $\mathrm{Ca}_{4} 4,80$, if washing is necessary a solution of the Na salt of TT at pH 8 should be used. 
(3) If more quantitative recovery of the $\mathrm{Ca} 45$ is desired, fraction 8 may be alternately shaken with fractions 7 and 9 until the desired recovery is attained.

(4) If there are no radiochemical impurities in fraction 5, dilute acid may be used here.

(5) The final solution may be extracted with benzene to remove last traces of TTA.

\author{
PROCEDURE 19 \\ STRONTIUH 90 \\ Source - B. P. Byhurst in "Collected Radiochemical Procedures", \\ Los Llamos report IL-1721. Jan. 1958.
}

\title{
1. Introduction
}

In the determination of strontium -90 the element is first separated as the nitrate. This is an excellent decontamination step, the major impurity being barium. The latter is removed by a series of barium chromate precipitations. The strontium is then converted to the carbonate, the chemical yield at this stage being about $75 \%$. Yttrium-90 is permitted to grow into equilibrium with the strontium -90 and the former is separated from the strontium by precipitation as hydroxide. Finally, yttrium is precipitated as oxalate and ignited to oxide, in which form it is counted. The chemical yield of yttrium is about $85 \%$, based on the quantity of strontium carbonate obtained.

\section{Reagents}

Sr carrier: $10 \mathrm{mg} \mathrm{sr} / \mathrm{ml}$ [added as $\mathrm{Sr}\left(\mathrm{NO}_{3}\right)_{2}$ in dilute $\mathrm{HNO}_{3} 7$

Fe carrier: $10 \mathrm{mg} \mathrm{Fe} / \mathrm{ml}$ (added as $\mathrm{FeCl}_{3} \cdot 6 \mathrm{H}_{2} \mathrm{O}$ in very dilute $\mathrm{HCl}$ )

$Y$ carrier: $10 \mathrm{mg} Y / m l$ (for preperation and standardization see yttrium procedure)

Ba carrier: $10 \mathrm{mg} \mathrm{Ba} / \mathrm{ml}$ [added as $\left(\mathrm{NO}_{3}\right)_{2}$ in $\left.\mathrm{H}_{2} \mathrm{O}\right]$

HCl: IM

HCl: conc. 


\section{FROCHWUT 19 (Cont'd.)}

$\mathrm{HNO}_{3}$ : ruming

$\mathrm{HNO}_{3}:$ conc.

$\mathrm{HC}_{2} \mathrm{H}_{3} \mathrm{O}_{2}$ : glacial

$\mathrm{NH}_{4} \mathrm{OH}$ : conc.

$\mathrm{Na}_{2} \mathrm{CO}_{3}$ : saturated aqueous solution

$\mathrm{NarO}_{4}$ : $10 \%$ aqueous solution

$\left(\mathrm{NH}_{4}\right)_{2} \mathrm{C}_{2} \mathrm{O}_{4}$ : saturated aquecus solution

$\mathrm{KClO}_{3}$ : solid

Ethanol: 95\%

\section{Equipment}

Bunsen burner

Steam bath

Drying oven

Muffle furnace

Centrifuge

Block for holding centrifuge tubes

Mounting plates

Forceps

Pipets: assorted sizes

wash bottle

Ice bath

Ground-off Hirsch funmels: Coors ooch (three per sample)

Filter chimneys (three per sample)

Filter flasks

Porcelain crucibles: Coors 000 (one per sample)

2", $60^{\circ}$ nunnels

No. 42 Whatman filter paper: $11 \mathrm{~cm}$

No. 42 whatman filter circles: $7 / 8^{*}$ diameter - weighed

40-ml conical centrifuge tubes: Pyrex 8320 (eight per sample; one per stendardization) 


\section{PROCEDURT 19 (Cont'd.)}

Stirring rods

Sintered glass crucible: 15-ml, fine porosity (one per standardization)

\section{Preparation and Standardization of Carrier}

Dissolve $247.5 \mathrm{~g}$ of $\mathrm{Sr}\left(\mathrm{NO}_{3}\right)_{2}$ in $\mathrm{H}_{2} \mathrm{O}$, add $10 \mathrm{ml}$ of conc. $\mathrm{HNO}_{3}$, and dilute to 1 liter with $\mathrm{H}_{2} \mathrm{O}$.

Into a 40-ml centrifuge tube, pipet $5.0 \mathrm{ml}$ of the carrier solution and add $15 \mathrm{ml}$ of saturated $\mathrm{Na}_{2} \mathrm{CO}_{3}$ solution. Stir and allow to stand for at least $15 \mathrm{~min}$. Filter the $\mathrm{SrCO}_{3}$ precipitate through a weighed $15-\mathrm{ml}$ (fine porosity) sintered glass crucible. Wash the precipitate with $10 \mathrm{ml}$ of water and then with $5 \mathrm{ml}$ of $95 \%$ ethanol. Dry in oven at $110^{\circ}$.

Four standardizations are carried out, with results agreeing within about $0.5 \%$.

\section{Procedure}

Step 1. Pipet $2.0 \mathrm{ml}$ of standard Sr carrier into a 40 -ml conical centrifuge tube. Idd an aliquot of sample and adjust the volume to about $5 \mathrm{ml}$ with $\mathrm{H}_{2} \mathrm{O}$. Ldd $30 \mathrm{ml}$ of cold (Note 1) fuming $\mathrm{HNO}_{3}$ and permit the mixture to stand in an ice bath for approximately 10 min. Centrifuge and discard the supernate.

Step 2. Dissolve the $\mathrm{Sr}\left(\mathrm{NO}_{3}\right)_{2}$ precipitate in $10 \mathrm{ml}$ of $\mathrm{H}_{2} \mathrm{O}$ and add 5 drops of Fe carrier. Make the solution basic by the dropwise addition of conc. $\mathrm{NH}_{4} \mathrm{OH}$ and then add 10 drops in excess. Stir, centrifuge, and decant the supernate into a precipitate.

Step 3. Add $2 \mathrm{ml}$ of glacial $\mathrm{HC}_{2} \mathrm{H}_{3} \mathrm{O}_{2}$ to bring the $\mathrm{pH}$ of the solution to 3.5 to 4.0 . Then add $2 \mathrm{ml}$ of $\mathrm{Ba}$ carrier and $2 \mathrm{ml}$ of $10 \% \mathrm{Na}_{2} \mathrm{CrO}_{4}$ solution and digest for 10 to $15 \mathrm{~min}$ on a steam bath with occasional stirring. Centrifuge, decant the supernate into a clean 40-ml centrifuge tube, and discard the precipitate.

Step 4. Add $5 \mathrm{ml}$ of saturated $\left(\mathrm{NH}_{4}\right)_{2} \mathrm{C}_{2} \mathrm{O}_{4}$ and digest on a steam bath for 5 to $10 \mathrm{~min}$. Centrifuge and discard the supernate. Wash the precip- 


\section{PROCRDUHR 19 (cont'd.)}

Itate by adding $2 \mathrm{ml}$ of saturated $\left(\mathrm{NH}_{4}\right)_{2} \mathrm{C}_{2} \mathrm{O}_{4}$ and $20 \mathrm{ml}$ of $\mathrm{H}_{2} \mathrm{O}$ and stirring. Centrifuge and discard the wash.

Step 5. Idd $2 \mathrm{ml}$ of conc. $\mathrm{HNO}_{3}, 5 \mathrm{ml}$ of $\mathrm{H}_{2} \mathrm{O}, \mathrm{stir}$, and then add $30 \mathrm{ml}$ of fuming $\mathrm{HNO}_{3}$. Allow to stand in ice bath for appraximately 20 min. Centrifuge and discard the supernate.

Step 6. Repeat Steps 2, 3, and 4.

Step 7. To the precipitate of $\mathrm{SrC}_{2} \mathrm{O}_{4}$ add $2 \mathrm{ml}$ of conc. $\mathrm{HNO}_{3}$ and about $200 \mathrm{mg}$ of $\mathrm{KClO}_{3}$. Carefully bring the solution to a boll and then boil vigorously for about 2 min.

Step 8. Idjust the volume to about $15 \mathrm{ml}$ with $\mathrm{H}_{2} \mathrm{O}$ and add 5 drops of Fe carrier. Make the solution basic by the dropwise addition of conc. $\mathrm{NH}_{4} \mathrm{OH}$ and then add $10 \mathrm{drops}$ in excess. Stir, centrifuge, and decant the supernate into a clean 40-ml centrifuge tube, discarding the precipitate.

Step 9. Repeat Step 3, except filter the $\mathrm{BaCrO}_{4}$ precipitate through a $2^{\prime \prime}, 60^{\circ}$ funnel on No. 42 Whatman filter paper. Collect the filtrate in a clean 40-ml centrifuge tube.

Step 10. To the filtrate add conc. $\mathrm{NH}_{4}$ OH until the solution is just basic. Then add $5 \mathrm{ml}$ of saturated $\mathrm{Na}_{2} \mathrm{CO}_{3}$ solution to precipitate $\mathrm{SrCO}_{3}$. Centrifuge and discard the supernate. Wash the precipitate with a mixture of $10 \mathrm{ml}$ of $\mathrm{H}_{2} \mathrm{O}$ and $2 \mathrm{ml}$ of saturated $\mathrm{Na}_{2} \mathrm{CO}_{3}$. Centrifuge and discard the wash. Slurry the precipitate and filter onto a weighed No. 42 Whatman filter circle, 7/8" diameter, contained in a ground-off Hirsch funnel-filter chimney setup. Wash the precipitate with $5 \mathrm{ml}$ of $\mathrm{H}_{2} \mathrm{O}$ and 5 ml of $95 \%$ ethanol, dry in an oven at $110^{\circ}$, and weigh (Note 2). Transfer the precipitate into a clean $40-\mathrm{ml}$ centrifuge tube and permit $\mathrm{I}^{90}$ to grow into equilibrium with the $\mathrm{Sr}^{90}$. (This requires about 18 dajs. Note 3.)

Step 11. After equilibrium has been attained, wash down the sides of the tube with 10 to $15 \mathrm{ml}$ of $\mathrm{IM} \mathrm{HCl}$. Add $2 \mathrm{ml}$ of standard $\mathrm{Y}$ carrier and stir. Slide the filter circle up the side of the tube with the stirring rod and, while holding the paper, wash with $I M$ HCI and remove it. 


\section{PROCADURE I9 (Cont'd.)}

Step 12. Add conc. $\mathrm{NH}_{4} \mathrm{OH}$ dropwise until $\mathrm{Y}(\mathrm{OH})_{3}$ precipitates and then add $5 \mathrm{ml}$ in excess. Centrifuge and save the supernate until the results of analysis for $Y$ have been checked. Record the time (Note 4 ).

Step 13. Dissolve the $\mathrm{Y}(\mathrm{OH})_{3}$ in a minimum of conc. $\mathrm{HCl}$ and add 15 ml of $\mathrm{H}_{2} \mathrm{O}$. Add $20 \mathrm{mg}$ of $\mathrm{Sr}$ holdback carrier and precipitate $\mathrm{Y}(\mathrm{OH})_{3}$ with excess conc. $\mathrm{NH}_{4} \mathrm{OH}$. Centrifuge and discard the supernate.

\section{Step 14. Repeat Step 13.}

Step 15. Wash the precipitate with $\mathrm{H}_{2} \mathrm{O}$, dissolve in a minimum of conc. $\mathrm{HCl}$, and add $15 \mathrm{ml}$ of $\mathrm{H}_{2} \mathrm{O}$. Again preclpitate $\mathrm{Y}(\mathrm{OH})_{3}$ with conc. $\mathrm{NH}_{4} \mathrm{OH}$ (this time in the absence of $\mathrm{Sr}$ carrier).

Step 16. Wash the precipitate and dissolve as in Step 15.

Step 17. Add $5 \mathrm{ml}$ of saturated $\left(\mathrm{NH}_{4}\right)_{2} \mathrm{C}_{2} \mathrm{O}_{4}$ solution (and a small amount of $\mathrm{HCl}$ if necessary) to precipitate $\mathrm{Y}_{2}\left(\mathrm{C}_{2} \mathrm{O}_{4}\right)_{3}$. Digest on a steam bath for 5 to $10 \mathrm{~min}$.

Step 18. Filter the $\mathrm{Y}_{2}\left(\mathrm{C}_{2} \mathrm{O}_{4}\right)_{3}$ precipitate onto a weighed No. 42 Whatman filter circle, $7 / 8^{\prime \prime}$ diameter, contained in a ground-off Hirsch fumel-filter chimney setup. Wash the precipitate with $\mathrm{H}_{2} \mathrm{O}$ and place in a porcelain crucible (Coors 000 ). Ignite at $900^{\circ}$ for $30 \mathrm{~min}$. Grind the $\mathrm{Y}_{2} \mathrm{O}_{3}$ into a powder with a stirring rod and add a few drops of ethanol. Continue grinding until the precipitate is smooth and transfer with $95 \%$ ethanol onto a weighed No. 42 Whatman filter circle, $7 / 8^{*}$ diameter. Wash down the sides of the filter chimney with ethanol, dry the precipitate in an oven at $110^{\circ}, \mathrm{cool}$, weigh, and mount.

\section{Notes}

1. Ey use of refrigerated fuming $\mathrm{HNO}_{3}$, the time required for cooling in an ice bath is recuced.

2. The $\mathrm{SrCO}_{3}$ formed in this step may be mounted and counted for $\mathrm{Sr}^{89}$.

3. The 18-day waiting period may be shortened provided a growth correction is made for the time interval between the centrifugation operations in Step 8 and Step 12. 
4. The time at wich $\mathrm{Y}^{90}$ is separated from $\mathrm{Sr} 90$ is recorded, 28 to and all $Y$ counts are corrected to this time.

\section{PROCEDURE 20}

STRONT IDY

Source - I. J. Bequ frit, Jr., and H. R. Lukens, Jr., page 122 in "Handbook of Radiochemical Analysis Volume II Radiochemical Procedures," U. S. Atomic Bnargy Comission report NP-5057 (Del.), Karch 5, 1952.

1. To the solution containing the strontium activity in volum of 5 to $8 \mathrm{ml}$ (in a 40-ml heavy wall contrifuge cono), add $\mathrm{Sr}$ carrier add 20 mg of Be cerrier, stir thoroughly, and let atend for ten winutes. Add $20 \mathrm{ml}$ of yellow suning $\mathrm{HnO}_{3}$ to procipitate $\mathrm{Bn}\left(\mathrm{MO}_{3}\right)_{2}$ and $\mathrm{Sr}\left(\mathrm{NO}_{3}\right)_{2}$ (Note a). Cool the solution in an ice bath for 30 mimites with occasional stirring. Centrifuge at low speed for flve udmtes, decant, and discard the supernate.

2. Dissolve the total precipitate with a minimim volume of water (about 2-3 ml) and repeat precipitation of the nitrates with funing $\mathrm{MNO}_{3}$ (Note a). Centrifuge as above, decant and discand the supernate. Dissolve the precipitate in 7 mil of water.

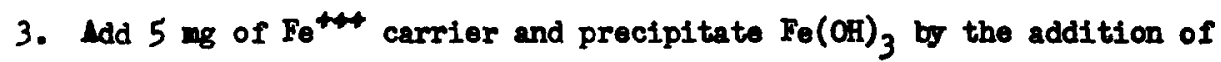
$2 \mathrm{ml}$ of $6 \mathrm{~N} \mathrm{NH} 4 \mathrm{OH}$ while stirring (Note b). Centrifuge and trans fer the supernate to a clean $40-\mathrm{ml}$ centrifuge cone. Wash the precipitate by slurrying with 7 al of $5 \% \mathrm{NH}_{4} \mathrm{NO}_{3}$ containing 2 drops of $\mathrm{NH}_{4} \mathrm{OH}$. Centrifuge, remove the wash solution, and combine with the supernate above. Discard the $\mathrm{Fe}(\mathrm{OH})_{3}$ scavenge precipitate.

4. Neutralize the combined supernates by the dropwise addition of $6 \mathrm{~N}^{2} \mathrm{ENO}_{3}$, testing the acidity with pH paper. Sdd $I$ wl of 6M HAc and 2 al of $6 \mathrm{M}$ $\mathrm{NH}_{4} \wedge$ c. Heat the solution nearly to bolling and add 1 mll of $1.5 \mathrm{M} \mathrm{Na}_{2} \mathrm{CrO}_{4}$ dropwise with stirring. Continue stirring the solution for one minute, then centrifluge. Decant the supernate into a clean 40-nl centrifuge cone. Discard the $\mathrm{HeCrO}_{4}$ precipitate. 
PROC.JPUR: 20 (Cont'd.)

5. Bxamine the supernate, and if it is not perfectly clear, centrifuge and discard aty residue. Add $2 \mathrm{ml}$ of $\mathrm{MH}_{4} \mathrm{OH}$, heat nearly to boiling, and add 5 ml of a saturated ammonium axalate solution slowly with stirring. Continue stirring for two minutes. Centrifuge, decant and discard the supernate.

6. Dissolve the $\mathrm{SrC}_{2} \mathrm{O}_{4}$ precipitate with $4 \mathrm{ml}$ of $6 \mathrm{~N}^{\mathrm{HNO}} \mathrm{O}_{3}$. Add $15 \mathrm{ml}$ of fuming $\mathrm{HNO}_{3}$, stir well and $\mathrm{coOl}$ in an ice bath for 20 mimites with occasional stirring. Centrifuge, decant and discard the supernate.

7. Dissolve the $\mathrm{Sr}\left(\mathrm{NO}_{3}\right)_{2}$ precipitate in $10 \mathrm{ml}$ of water, neutralize the solution with $\mathrm{MH}_{4} \mathrm{OH}$, hent nearly to boiling and add 2 ml of $\mathrm{II} \mathrm{Na}_{2} \mathrm{CO}_{3}$ solution slowly with stirring. Heat gently for several minutes and allow to cool in an ice bath for 10 minutes.

8. Have ready a Whatman No. 42 filter disc which has been previously prepared by washing it with three 5-ml portions of $\mathrm{H}_{2} \mathrm{O}$ and three 5-ml portions of ethanol. Dry in an oven at 90-100 C for 10 minutes, cool in a desiccator for 10 minutes and weigh. Repeat this procedure until a constant weight $( \pm 0.1 \mathrm{mg})$ has been obtained.

9. Filter the $\mathrm{SrCO}_{3}$ onto the prepared filter paper. Wash, dry, and weigh the precipitate according to the fllter paper treatmont in step 8 . Weigh as $\mathrm{SrCO}_{3}$, mount, and count.

\section{NOTES}

a. At least three volumes of fuming $\mathrm{HNO}_{3}$ should be added to insure the quantitative precipitation of the nitrates.

b. The addition of several drops of a $1 \%$ aerosol solution will help prevent creepage. 


\section{STROMTIOM}

$$
\begin{aligned}
& \text { Source - S. Castnor in report } A B C D-2738, \\
& \text { edited by W. W. Hainke, Lugust } 1949 .
\end{aligned}
$$

Target matertal: $\mathrm{BbCl}(\sim 30 \mathrm{mg})$ finely divided

Type of bombardient: 184" deuterons and protons
Ttwe for separation: 35 win without columin; $1-1 / 2$ hr with colum

Equipment required: 1 wl cones, plpottes, ete.

\section{Iield: in $90 \%$}

Degree of purtfication: Brcellont - 2 5\% for contemination without colvm. $.2 \%$ or less ito contamination with colven.

Ldvantages: Outek, nay be modified to give carrier froe Sr.

Procedure:

(1) Dissolve target in $500 \lambda$ of $\mathrm{Ba}_{2} \mathrm{C}_{2} \mathrm{O}_{4}(3 \mathrm{gmo} / 100 \mathrm{ml})$. Boat in bolling water for 1 in. stir.

(2) Idd Sr carrier, stir and cool in ice bath contrifuge, withdraw the

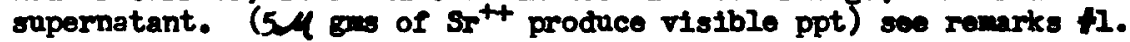

(3) Wash the precipitate with $\mathrm{M}_{2} \mathrm{C}_{2} \mathrm{O}_{4}$ (500 $\lambda$ ), stirring up and then contrifuging and discarding the wash solution.

(4) Repeat wash 3 times.

(5) Wash with $\mathrm{B}_{2} \mathrm{O}(500 \lambda$ ) twice (see remarks) 12 .

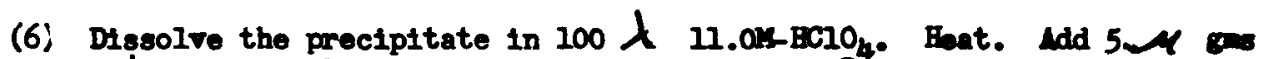
Ebt, stir, cool in ice bath and centrifuge. This gives the st practicaliy carrior froe in $\sim 100 \lambda$ of solution.

Remarks:

(1) and (2) Whilo $5 \mu$ gus of Sr+t produce a visible precipitate as stated when washed with $1 \mathrm{ml}$ of $\mathrm{H}_{2} \mathrm{O}, 25 \%$ of the precipitate will dissolve.

(3) If carrier free $\mathrm{Sr}^{++}$is destred, $10 \mathrm{~W}$ gmo of $\mathrm{Ba}+4$ carrier mas be added Instead in step (2). The prectpitate is not washed but is dissolved in $0.1 \mathrm{M} \mathrm{BCl}$ and placed on a 2 dianeter fon exchange colum, 2" long. The $\mathrm{Sr}^{++}$comes off well after the $\mathrm{Fb}^{+}$. (Flow rate of $\backsim 1$ drop/2.5 min.)

$\mathrm{SrCO}_{3}$ carries $\mathrm{Ft}$ with it in large quantities. 


\section{STRONIIUM}

Source - R. H. Goeckermann in report AECD-2738, edited by W. W. Meinke, August 1949.

Target material: approximately $1 \mathrm{~g}$ Bi metal

Type of bombardment: $184^{*}$ all particles
Time for separation: 1-2 hrs.

Equipment required: Centrifuge, tubes, 1ce, vacuum dessicator

Yield: aporoximately $80 \%$

Degree of purification: Decontamination factor approximately $10^{4}$ from fisston and spallation products. $S_{r}$ decontaminated $>100$ from Ba.

Advantages: Good yield of $\mathrm{Ba}$ and $\mathrm{Sr}$, separation from all other elements except $\mathrm{Ra}$, very good separation of $\mathrm{sr}$ and Ba from each other.

Procedure:

(1) To aliquot of HNO solution of target, add $10 \mathrm{mg} \mathrm{Sr}$ and $\mathrm{Ba}, 30 \mathrm{ml}$ fuming $\mathrm{HNO}_{3}$, digest cold $1-2$ min.

(2) Dissolve precipitate in $2 . \mathrm{ml} \mathrm{H}_{2} \mathrm{O}$ and reprecipitate with $15 \mathrm{ml}$ fuming $\mathrm{HNO}_{3}$.

(3) Dissolve precipitate in 5-10 $\mathrm{ml} \mathrm{H}_{2} \mathrm{O}$, add $5 \mathrm{mgFe}+3$, and precipitate $\mathrm{Fe}(\mathrm{OH})_{3}$ with tank $\mathrm{NH}_{3}\left(\mathrm{CO}_{3}=\right.$ free! $)$ Repeat $\mathrm{Fe}(\mathrm{OH})_{3}$ scavenge.

(4) Neutralize supermatant with $6 \mathrm{~N} \mathrm{HNO}$, add $1 \mathrm{ml} 6 \mathrm{ki}$ HAc and $2 \mathrm{ml}$ $6 \mathrm{M} \mathrm{NH} 4 \mathrm{Ac}$. Heat to boiling and add $1 \mathrm{ml} 1.5 \mathrm{M} \mathrm{Na}_{2} \mathrm{CrO}_{4}$ dropwise with stirring. Digest one min. (Save the supernatant for $\mathrm{Sr}$ fraction).

(5) $\mathrm{Sr}$ - Precipitate $5 \mathrm{mg} \mathrm{BaCrO}_{4}$ scavenge from supernatant saved from $\mathrm{Ba}$ separation. Add $2 \mathrm{ml}$ conc. $\mathrm{NH} 4 \mathrm{OF}$, heat, add $5 \mathrm{ml}$ saturated $\left(\mathrm{NH}_{4}\right)_{2} \mathrm{Ox}$ slowly. Stir 2 min, filter, wash three times with $5 \mathrm{mI} \mathrm{H} \mathrm{O}$, three times with $5 \mathrm{ml}$ EtOH, three times with $5 \mathrm{ml}$ ether, dry like $\mathrm{BaCl}_{2}$. Weigh as $\mathrm{SrC}_{2} \mathrm{O}_{4} \cdot \mathrm{H}_{2} \mathrm{O}$ (22.I mg per $10 \mathrm{mg} \mathrm{Sr}$ ).

Remarks: Procedure adapted for use when Sr activity much greater than Ba. $\mathrm{Ra}$ follows the $\mathrm{Ba}$ well, can be separated from it by use of a resin column. 
Source - A. S. Newton in report $\triangle \mathrm{ECD}-2738$

oditod by W. W. Lainke, dagust 1949.

Target material: Thorium matal (.1-1 gm) Time for separation: $1 \mathrm{hr}$.

Type of bombardment: 60" alphas

Equipmont requitrod: Standard

Iield: $75 \%$ on $\mathrm{Sr}$

Degree of purification: $10^{6}$ from other Flsaion Products, approximately $10^{3}$ rroa barium

ldvantages: Ba and $\mathrm{Sr}$ can be taken out in same procedure.

Procedure: The Th metal is dissolved in conc BCl plus a few drops of .2 $\mathrm{H}\left(\mathrm{NH}_{4}\right)_{2} \mathrm{SH} 6$ to cloar up the black residue. The $\mathrm{BCI}$ is diluted to $2 \mathrm{I}$ and an aliquot taken.

(1) Idd $20 \mathrm{mg}$ each Be and Sr carrter and $30 \mathrm{ml}$ funing nitric acid. $\mathrm{CoOl} \mathrm{1-2} \mathrm{mimutes} \mathrm{with} \mathrm{stirring} \mathrm{and} \mathrm{centrifuge.} \mathrm{(If} \mathrm{SO}_{4}$ present add $\mathrm{H}_{2} \mathrm{SO}_{4}$ to precipttate $\mathrm{BaSO}_{4}$. Wash with $10 \mathrm{ml}$ Ho. Jetuthesteo with $50 \mathrm{~S}_{2} \mathrm{~K}_{2} \mathrm{CO}_{3}$ by boiling $5 \mathrm{mtn}$. Contrifuge, wash with water. Dissolvo proctpitate in $1 \mathrm{I} \mathrm{BNiO}_{3}$. Discard residue. Then make raming nitric acid precipitation.).

(2) Dissolve precipitate in $2 \mathrm{ml}$ B2O. Roprectpitate with 15 al raming Bliby.

(3) Dissolve prectpitate in 5 to $10 \mathrm{ml} \mathrm{B}$. Add $5 \mathrm{mg} \mathrm{Fet+,} \mathrm{precipitate}$ $\mathrm{Pe}(\mathrm{OH})_{3}$ by adding 2 ml carbonate free $6 \mathrm{M}$ MR4 $\mathrm{OH}$ or pass in $\mathrm{NH}_{3}$ gas to precipitate $\mathrm{Fo}(\mathrm{OH})_{3}$. Contrifuge.

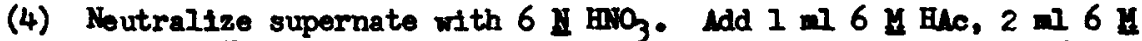

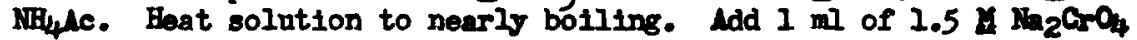
dropwise with stirring. Lot stand I min. Centrifuge. Reserve supernate for sr.

(5) To clear supernate add $2 \mathrm{ml}$ conc $\mathrm{NH}_{4} \mathrm{OH}$. Hoat nearly to boiling. Idd $5 \mathrm{ml}$ saturated ammoniun oxalate slowly with stirring. Stir 1-2 min.. filter with suction into a weighed filter paper. Wash three times with $5 \mathrm{ml}$ dil hot $\mathrm{NH}_{4} \mathrm{OH}$, three times with 5 ml $95 \%$ EtOH, three times with $5 \mathrm{ml} \mathrm{Bt}_{2} \mathrm{O}$. Dry by racum $2 \mathrm{~min}$, release, 5 min. Woigh as $\mathrm{SrC}_{2} \mathrm{O}_{4} \cdot \mathrm{H}_{2} \mathrm{O}$.

Remarks: This procedure has been described previously (Phys. Rev. 2517 (1949)).

Breparation of carrier solution: Dissolve $24.1 \mathrm{gmos}$ of $\mathrm{Sr}\left(\mathrm{NO}_{3}\right)_{2}$ in water and dilute to 1 liter.

Standardiration: Take $5 \mathrm{ml}$ carrier add $30 \mathrm{ml} \mathrm{H} \mathrm{H}_{2}$. Add $5 \mathrm{ml}$ saturated oxalic acid and heat neariy to boiling. Idd $2 \mathrm{ml}$ cone $\mathrm{MH}_{4} \mathrm{OH}$ dropwise with stirring. Iot stand 10 minutes, $\infty 01$ in tep water. Filter into a sintered glass crucible. Wash 3 times with hot water containing a slight amount of $\mathrm{kH}_{4} \mathrm{OH}$, three times with $95 \% \mathrm{BtOH}$ and three times with 5 mil portions $\mathrm{Bt}_{2} \mathrm{O}$. Evacuate in vac desiccator for $2 \mathrm{~min}$, release vac and evacuete five minutes longer, and weigh as $\mathrm{SrC}_{2} \mathrm{O}_{4} \cdot \mathrm{H}_{2} \mathrm{O}$. Repert evacuations until weight constant to $0.2 \mathrm{mg}$. 
PROCEDURS 24

\section{STRONTIUM}

Source - D. 2. Itppmam and R. H. Goeckermann in report 1 SECD-2738 odited by W. W. Hoinke, August 1949.

Target material: Au foll, about 1 g Time for separation: $1 \mathrm{hr}$. for Sr

Type of bombardment: Full energy

protons, helium tons, or douterons

Equipment required: Ice bath and hot water bath

Iield: Sr $50 \%$

Degree of purification: Good - about $10^{5}$ from Au and spallation products and at least $10^{3}$ from fission products.

Idvantages: Sr, Ba, and Ho can all be separated from the same target matertal.

Procedure:

Dissolve target in hot solution containing $10 \mathrm{mg}$ each of $\mathrm{Sr}, \mathrm{Ba}$, and Ho, $5 \mathrm{ml}$ of $12 \mathrm{M} \mathrm{HCl}$ and $5 \mathrm{ml}$ of ruming $\mathrm{HNO}_{3}$. Cool solution in ice bath, and slorrly add about $30 \mathrm{ml}$ ruming $\mathrm{HNO}_{3}$. $\mathrm{Sr}\left(\mathrm{NO}_{3}\right)_{2}$ and $\mathrm{Ba}\left(\mathrm{NO}_{3}\right)_{2}$ precipitate. Centrifuge.

Dissolve prectpitate in $5 \mathrm{ml} \mathrm{H}_{2} \mathrm{O}$, add $5 \mathrm{mg} \mathrm{Fo}$, warm in hot water bath, and pxeqipitate $\mathrm{Fe}(\mathrm{OH})_{3}$ with $6 \mathrm{~K} \mathrm{NH} 4 \mathrm{OH}$. Contrifuge. If desired add more $\mathrm{Pe}$ III and centrifuge out $\mathrm{Fo}(\mathrm{OH})_{3}$ again. Neutralize supernatant

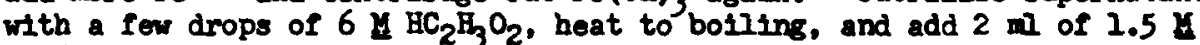
$\mathrm{Na}_{2} \mathrm{CrO}_{4}$ droporise. Digest $\mathrm{BaCrO}_{4}$ prectpitate in hot water bath and contrifuge.

Beat supernatant from first $\mathrm{BaCrO}_{4}$ precipitation to boiling, add $1 \mathrm{ml}$ of Ba carrier dropwise, digest in hot water bath, and centrifuge. To supernatant add $2 \mathrm{ml}$ of $15 \mathrm{M} \mathrm{NH} 4 \mathrm{OH}$ (color of solution should just change from orange to yellow), beat to bolling, add 5 ml saturated $\left(\mathrm{NH}_{4}\right)_{2} \mathrm{C}_{2} \mathrm{O}_{4}$ dropwise, digest in hot water bath, cool, filter, wash three times with $5 \mathrm{ml} \mathrm{B}_{2} \mathrm{O}$, three times with $5 \mathrm{ml}$ alcohol, and three times with $5 \mathrm{ml}$ other. Dry in a vacuum destccator by pumping 2 minutes. letting in air, and then pumping for 5 more minutes. Weigh as $\mathrm{SrC}_{2} \mathrm{O}_{4} \cdot \mathrm{B}_{2} \mathrm{O}$.

Remarks:

Al additions of fuming or concentrated $\mathrm{HNO}_{3}$ should be made cautiously: they tend to react violently after a short Induction period.

\section{PROCEDURE 25}

\section{STRONTIM}

Source - R. I. Folger and i. Hicks in report AECD-2738

odited by W. W. Motnke, August 1949.

Target material: Appr.4 g 0 motal

Type of bombardment: 184" all high energy particles
Time for separation: 1-2 hrs.

Equipment required: Centrifuge, tubes, ice, vacuum desiccator 


\section{Iteld: app, $80 \%$}

Degree of purteication: Decontamination factor $\sim 10^{4}$ from fission and spellation products. Sr decontaminated $>100$ from Ba.

Advantagess Good yield of Ba and Sr, separation from all other elements except $\mathrm{Ra}$, very good separation of $\mathrm{Sr}$ and Ba from each other, and Sr from Ra (which follows $\mathrm{Ba}$ ).

Procedure:

(1) To aliquot of $\mathrm{HWO}_{3}$ solution of target containing $10 \mathrm{mg}$ each $\mathrm{Sr}$ and $\mathrm{Ba}$, and reduced in volume to aporoximately $1.5 \mathrm{ml}$, add $22-13 \mathrm{ml}$ funtre $\mathrm{BR}_{3} \mathrm{O}_{3}$, digest cold 5 atn.

(2) Dissolve prectoitate in $I$ al $B_{2} \mathrm{O}$ and roprecipitate with approximately $13 \mathrm{ml}$ fuming $\mathrm{HNO}_{3}$.

(3) Dissolve prectpitate in $5 \mathrm{ml} \mathrm{B}_{2} \mathrm{O}$, add 2 mFet3, and precipitate $\mathrm{Fo}(\mathrm{OH})_{3}$ with tank $\mathrm{NH}_{3}\left(\mathrm{CO}_{3}=\right.$ free!) Repeat $\mathrm{Po}(\mathrm{OH})_{3}$ scavenge (I w $\mathrm{Fo}+3$ ).

(4) Noutralize supernatant with conc. Elio to mothyl orange and point, add $1 \mathrm{ml} 6 \mathrm{y}$ Hic and $2 \mathrm{ml} 6 \mathrm{y} \mathrm{NH} 4 \mathrm{Ac}$. Heat to boiling and add $1 \mathrm{ml}$ of $1.5 \mathrm{I} \mathrm{Na}_{2} \mathrm{CrO}_{4}$ dropwise with stirring. Digest one min. (Save the supernatant for $\mathrm{Sr}$ (raction).

(5) Precipitate $5 \mathrm{mg} \mathrm{BaCrO}_{4}$ scarenge from supernatant saved from Ba separation. Idd 2 ml conc. $\mathrm{KR}_{4} \mathrm{OH}$, heat, and precipitate $\mathrm{SrCO}_{3}$ by adding saturated $\mathrm{Na}_{2} \mathrm{CO}_{3}$. Digest 2 min, centrifuge and dissolve in 6 I HCI (minimam). Bolil out $\mathrm{CO}_{2}$.

(6) Make basic with $\mathrm{NH}_{3}$ and add saturated $\mathrm{Ne}_{2} \mathrm{C}_{2} \mathrm{O}_{4}$. Stir 2 dn (hot), cool, filter, wash three times with $5 \mathrm{ml} \mathrm{H}_{2} \mathrm{O}$, three times with $5 \mathrm{ml}$ BtOB, three timos with $5 \mathrm{ml}$ other, dry like $\mathrm{BaCl}_{2}$. Weigh as $\mathrm{SrC}_{2} \mathrm{O}_{4} \cdot \mathrm{H}_{2} \mathrm{O}$ (22.1 ig per $10 \mathrm{mg} \mathrm{Sr}$ ).

Remarks: Procedure adapted for use when Sr activity much greater than Ba. Ra follows the Ba woll, can be separated from It by use of a resin colunin. See ARCD 1998 (Edward R. Tompins)

In stop (4) add 1 drop Ne-orange to the solution before neutralization starts. 


\section{PROGBDUR: 26}

\section{STRONTIUM}

Source - P. C. Tomplins, A. Broido, G. W. Parker, E. R. Tompldins, W. E. Cohn, W. Kisieleskd, and R. D. Pinklo, Paper 2/,0 in Radiochemical Studies, The Fission Products", edited by C. D. Coryell and N. Sugarmen, MoGraw-Bull Book Co., Inc., Now Iork, 1951.

PROCEDURE FOR SEPARATING STRONTIUM FROM PIIX-URANIUM SOLUTION

(I) Pile Urantur Dissolved in Conc.

ENO3. Dilute solution to $0.5 \mathrm{~N}^{2} \mathrm{NH}_{3}$; add $1.5 \mathrm{~g}$ of $\mathrm{PbCl}_{2}$ per liter of solution; add $70 \mathrm{ml}$ of $9 \mathrm{M} \mathrm{H} \mathrm{H}_{2}$ per liter of solution (use continuous atirring for $1 \mathrm{hr}$ ); allow $\mathrm{PbSO}_{4}$ to settle; decant supernatant solution.

(2) Precipitate. $\mathrm{PbSO}_{4}$. Wash with $\mathrm{H}_{2} \mathrm{O}$, discard washings; add $50 \mathrm{ml}$ of sat. $\mathrm{N}_{2} \mathrm{CO}_{3}$, stir, and decent solution.

(3) Precipitate. $\mathrm{PbCO}_{3}$. Wash with $\mathrm{H}_{2} \mathrm{O}$ discard washings; add $50 \mathrm{ml}$ of $3 \mathrm{M}$ $\mathrm{HCl}$, evaporate to low volume, cool, and centrifuge.

(4) Solution. Boil with HarO 3 ; add 1 me each of $\mathrm{Ce}_{\theta}, \mathrm{La}$, and $\mathrm{I}$; add $50 \mathrm{ml}$ of $\mathrm{H}_{2} \mathrm{O}$ and $50 \mathrm{ml}$ of fuming $\mathrm{KNO}_{3}$, and centrifuge.

(5) Precipitato. $\mathrm{Pb}\left(\mathrm{NO}_{3}\right)_{2}, \mathrm{Ba}$, and Sr activities. Reprecipitate three times; and add $5 \mathrm{ml}$ of IN HCl; heat, cool, and contrifuge.

(6) Solution. Evaporate to $1 \mathrm{ml}$, add $4.5 \mathrm{ml}$ of conc. $\mathrm{HCl}, 1 \mathrm{ml}$ of ether, and $10 \mathrm{mg}$ of $\mathrm{Ba}$ in two portions; centrifuge.

(7) Solution. Braporate to small volume. sdd $0.3 \mathrm{~N} \mathrm{HCI}$, heat to $80 \mathrm{C}$, saturate with $\mathrm{H}_{2} \mathrm{~S}$; filter.

(8) Solution. Sr (7a) Precipitate.

activity. Braporato POS. Discard. to drynoss*; add dil. HCl.
(9) Solution. Sr activity.

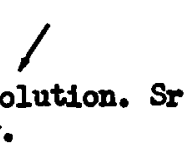

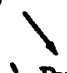

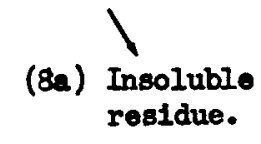

Found 3 ig of restdue here. 


\section{PROCEDURB 27}

STRONTIUM

Source - R. Overstreet, I. Jacobson, R. Scott, and J. G. Handlton, Paper 241 in "Badiochemical Studies: The Fission Products", odited bo C. D. Coryell and N. Sugarman, McCraw-Hill Book Co., Inc., New Iork, 1951.

\section{PROCEDURE}

A sample of $\mathrm{BbCl}$ was bomberded on a copper target with $300 \mathrm{~K}$ a-hr of deuterons at the 60-in. Berkeley cyclotron. Five degs later the target was treated with $0.1 \mathrm{~N} \mathrm{HCl}$. The resulting solution was filtered and made up to $0.3 N$ with HCI. The copper was precipitated with $\mathrm{H}_{2} \mathrm{~S}$ and filtered off. Fifty miligrams of zinc as $\mathrm{ZnCl}_{2}$ was added to the filtrate. The solution was made alkaline with $\mathrm{MH}_{4} \mathrm{OH}$, and the zine was precipitated with $\mathrm{H}_{2} \mathrm{~S}$. The filtrate from the $\mathrm{ZnS}$ precipitation was acldifled and concentrated to about $25 \mathrm{ml}$. Fifty milligrams of iron carrier as $\mathrm{FoCl}_{3}$ was added. Equal volumes of ammonium carbonate reagent $\left[\mathrm{ON}\left(\mathrm{NH}_{4}\right)_{2} \mathrm{CO}_{3}\right.$ in $6 \mathrm{~N} \mathrm{NH}$ and the resulting solution was brought to boiling. The $\mathrm{Fe}(\mathrm{OH})_{3}$ precipitate was filtered off and washed with $3 \mathrm{~N} \mathrm{NH}_{4} \mathrm{OH}$. About 75 per cent of the activity was retained in the precipitate. $\mathrm{The} \mathrm{Fe}(\mathrm{OH})_{3}$ precipitate was dissalved in 1N BCl, and $50 \mathrm{mg}$ of $\mathrm{RbCl}$ was added. The iron was reprecipitated with an equal rolume of the $\left(\mathrm{MH}_{4}\right)_{2} \mathrm{CO}_{3}$ reagent, and the $\mathrm{Fe}(\mathrm{OH})_{3}$ was centrifuged down. The precipitate was dissolved in $\mathrm{IN} \mathrm{HCl}$ and reprecipitated three more times with the $\left(\mathrm{NP}_{4}\right)_{2} \mathrm{CO}_{3}$ reagent. In each case the supernatant solution was found to be inactive. The precipitate was flinally dissolved in $6 \mathrm{~N} \mathrm{KCl}$, and the solution was extracted with several portions of ether to remove the iron. The iron-free solution was evaporated to dryness, and the residue was heated gently to remove $\mathrm{NH}_{4} \mathrm{Cl}$. The residue was taken up in dil. $\mathrm{HCl}$.

\section{TESTS}

To a small frection of the final strontium tracer solution, $10 \mathrm{mg}$ esch of zinc, Jttrium, rubidium, and strontium carriers was added. The zinc and yttrium were precipitated in alkaline solution with $\mathrm{H}_{2} \mathrm{~S}$. The strontium was precipitated trom the filtrate with $\left(\mathrm{NH}_{4}\right)_{2} \mathrm{CO}_{3}$ reagent and ethyl alcohol. 
PROCEDURE 27 (Cont id.)

The activities of the sinc and yttriun frection, the strontinm fraction, and the rubidium fraction were deternined with an electroscope. Of the total activity, 98.5 per cent was associated with the strontiun fraction. The absorption curves determined for the strontiun prepared wi thout carrier and for the radiostrontiun precipitated and purifled with strontinn cerrter were found to be identicel.

\section{PROCEDURE 28}

\section{STRONTIUM}

Source - J. C. Dalton and G. A. Welch in Anal, Chim. Acta 15, 317 (1956). THE RAPID SEPARATION AND DETERMINATION OF RADIOSTRONTIUM AND RADIOCAESIUM IN FISSION PRODUCT N.IXTURES

A technique has been described $\mathbf{1 1}^{\mathbf{1}}$ for precipltating cations and removing them from solution without the use of filtration or centrifugation, by passing the solutions through anion exchange resin beds saturated with the precipitating anion. The precipitate forms around the resin beads as an adhering film, and the eluate from the column is clear. Hore recently the technique has been applied with success to the precipitation of radioactive tracers in the carrier-free state. ${ }^{72}$ Employing a column in the hydroxide form the authors have removed all the activity from an aged fission product solution with the exception of that due to radiostrontium and radiocaesium. Any anionic activity was removed by normal ion exchange processes, while all the other long-lived cationic activity was precipitated on the hydroxide colum. Separation of the strontium and caesium in the eluate was then carried out prior to the precipitation of each element in a form suitable for counting after gravimetric determination of chemical yield. By this mans the determinations of these two elements were accomplished more rapidly and with better precision than by existing procedures. 73 Under conditions of routine use, 8 determinations of each radioelerent were made simultaneously in under 2 days per operator and the 
precisions obtained ( $3 \sigma$ for about 30 results) were $10 \%$ for strontium and $8 \%$ for caestum.

\section{EXPERIMENTAL}

Miquots of fission product solution (at least several months old and therefore containing very little El 140 (12.8d) with added known amounts of caesium and strontium carriers were passed down colums of Amberlite IR $-400(\mathrm{OH})$ and eluted with several column volumes of water. The eluates were heated almost to boiling and saturated ammonium oxalate was then added to precipitate the strontium. The precipitates were centrifuged off, washed several times with water, dried, weighed and counted. After correcting to $100 \%$ chemical yield, the results showed a good accuracy and precision.

The supernatant solutions frcm the oxalate precipitations were made about $5 \mathrm{M}$ in hodrochloric acid and an $0.1 \mathrm{M}$ solution of silicotungstic acid was added to precipitate the caesium. This again was centrifuged off, washed, dried, weighed and counted. Wany of the sources became discoloured on drying, and this discoloration was associated with poor agreement among the results from the individual sources. It appeared that the caesium silicotungstate was unsuitable as a method of gravimetric determination. Several other reagents were considered (.,$g$. see reference 74 ), but eventually it was decided to employ perchloric acid.75 The solution had to be free from any ammonium ion during this precipitation of caesium, because ammonium perchlorate also precipitates under the conditions used. Therefore, either the ammonium oxalate used in the preclpitation of strontium had to be volatilized, or else the caesium and strontium had to be separated without the use of ammonium oxalate. The removal of ammonium oxalate by volatilization was avoided as it would prove time consuming, and a rapid separation was being sought. Using a colum of anion exchange resin in the oxalate form, the strontium could be removed from the caesium without the introduction of any cation which would interfere in the subsequent precipitation of caesium as perchlorate. However, the strontium carrier immediately precipitated as a pad on top of the resin, and this slowed down the colum flow-rate to such an extent that it made its use in a routine method impracticable.

$\Delta$ mach simpler and more rapid separation was effected by the addition of carbon dicxide (in the solid state for convenience) to the eluate from the hydroxide colum. Thus the strontium was removed quantitatively without the addition of any interfering cation. The caesium could then be precipitated as perchlorate, while the strontium carbonate was dissolved in acid and the strontium reprecipitated as caalate.

Analysis of the strontium sources by $O$-absorption measurements showed the activity to be entirely due to $\mathrm{Sr} 89, \mathrm{Sr} 90^{8}$ and $\mathrm{Y} 90$. The last-named isotope begins to grow in from its $\mathrm{Sr}^{90}$ parent after chemical separation has occurred. Only negligible traces of $Y$-activity were observed in the scurces. $y$-spectrometric analysis of the caesium sources showed them to be more than $99 \% \mathrm{Cs} 137 / \mathrm{Ba} 137 \mathrm{~m}$ with a trace of $\mathrm{Cs} 134$.

Reagents

Strontium carrier solution $\left(9.5 \mathrm{~g} \mathrm{SrCl}_{2} \cdot 6 \mathrm{H}_{2} \mathrm{O}\right.$ in $100 \mathrm{ml}$ water). Caesium carrier solution (2.75 $\mathrm{g} \mathrm{CsCl}$ in $100 \mathrm{ml}$ water). (The strontium and caesium contents of the respective solutions should be determined accurately by normal gravimetric procedures).

Carbon dioxide (solid or from Kipp's Apparatus). 
Procedure

The columns should be $40-50 \mathrm{~cm}$ long, $1.2-1.4 \mathrm{~cm}$ internal diameter and should contain 8-10 $\mathrm{g}$ Amberlite IRA-400 (OH) resin. Before use, wash the colums with about $50 \mathrm{ml}$ of $4 \mathrm{M}$ nitric acid to remove any retained activity from previous experiments. Remove the excess of acid with water, then pour through the colums a strong sodium hydroxide solution prepared from carbondioxide-free distilled water. Fit an absorption tube containing soda-lime in the top of each column. Remove the excess of sodium hydroxide by washing.

Pipette an aliquot of the solution for analysis, which should contain negligible amounts of Ballo into a small beaker and add $2.0 \mathrm{ml}$ of both caesium and strontium carrier solutions. The aliquot should be chosen to contain quantities of activity suitable for gounting. The strontium-89 activity should be between $3 \times 10^{3}$ and $1.5 \times 10^{6}$ disintegrations per minute and the caesium-137 activity $2 \times 104$ to $6 \times 105 \mathrm{dpm}$. In addition, the aliquot should not contain more than four milliequivalents of anion other than hydroxyl, otherwise the effectiveness of the colurn may be impaired owing to replacement of the hydroxyl ions by other non-precipitating anions.

Transfer the solution and washings into the colum and allow the liquid to flow through slowly at a rate of $0.5-1 \mathrm{ml}$ per minute. Collect the eluate in a $150 \mathrm{ml}$ beaker, and when the liquid level in the colum has almost reached the level of the resin, add distilled vater. Continue the elution until about $40 \mathrm{ml}$ has been collected, then precinitate the strontium with carbon dioxide. (If solid carbon dioxide is being used add 1-2 g.) Centrifuge off the precipitate and dissolve it in a little dilute hydrochloric acid and dilute to about $20 \mathrm{ml}$ with water. Retain the supernate from the precipitation for the determination of caesium.

Boil the strontium solution to expel any carbon diaxide, cool, add $2 \mathrm{ml}$ of $18 \mathrm{M}$ ammonium hydroxide and heat again almost to boiling. Slowly add $5 \mathrm{ml}$ of saturated ammonium oxalate solution, and allow the beaker and its contents to cool. Centrifuge off the precipitate, wash it several times with water and then transfer it as a slurry with acetone to a weighed stainless steel or glass counting tray. Dry the precioitate carefully, weigh it and count the source without delay.

Standard G.M. counting equipment with a total absorber thickness of $130-140 \mathrm{mg} / \mathrm{cm}^{2}$ should be used. Thus the $0.6 \mathrm{MeV} \beta$-activity of $\mathrm{sr} 90$ is absorbed and only the $1.5 \mathrm{MeV} \rho$-emission of $\mathrm{Sr}^{89}$ is counted. However, Y 90 the daughter element of $\mathrm{Sr}^{90}$ commences to grow in with a half-life of 61 hours immediately after elution from the colums, and the energy of its $\beta$-radiation is $2.2 \mathrm{keV}$. The time interval between the colum separation and the counting should therefore be noted. Recount the sample several days later, using the same equipment, and note the time of counting. Correct the counts for counting efflciency, background, back-scatter and self-absorption as necessary. Calculate the fraction of the total Y 90 which has grown in during the interval between the first and second countings, and hence find the $\mathrm{Sr} 90$ activity. The amount of $\mathrm{Y} 90$ activity present during the first counting is therefore known, and by difference calculate the $\mathrm{Sr}^{89}$ activity.

Fume down the suptrnate containing the caesium with $6 \mathrm{ml}$ of $9 \mathrm{~N}_{\mathrm{H}}$ perchloric acid. After fuming has continued for 10 minutes, cool the mixture in a $50 \mathrm{ml}$ centri fuge tube in an ice-bath. Add $15 \mathrm{ml}$ of absolute aloohol and allow to stand for 10 minutes, stirring occasionally. Centrifuge off the precipitate, wash it several times with absolute alcohol and transfer it as a slurry with acetone to a weighed stainless steel or glass counting tray. Dry under a radiant heater, weigh and count the source. 


\section{PROGWURis 28 (Cont Id.)}

Standard $Y-8$ cintillation counting equipment fitted with a $2 \mathrm{~g} / \mathrm{cm}^{2}$ absorber of lead and aluminium (to prevent formation of Bresstrehing ) should be used. The $y$-rays are actually emitted by Balim, the meta-stable daughter, which has a half-life of 2.6 minutes and therefore quickly reaches oquilibrium. Corrections are made for counting efficiency (including the absorber) and also for the fact that only $82.5 \%$ of the total Cs 137 disintegrations produce $Y$-rays from $\mathrm{Ba} 137 \mathrm{~m}$, the rest being lost either by direct decay to stable 137 , or else by interval conversion of the $Y$-rays.76

\section{PROCLDURE 29}

\section{STRONTIUN}

Source - E. A. Martell in "The Chicago Sunshine Method", U. S. Atomic Energy Commission Report $1 \mathrm{ECU}-3262$, page 47, May, 1956.

\section{Ion Exchange Procedure for $\mathrm{Sr}^{90}$ in Water Samples}

(Nuclear Science and Engineering Corporation Method)

Summary

The $\mathrm{Sr}^{90}$ in water samples may be concentrated by passing the water through an ion exchange colum. The $\mathrm{Y}^{90}$ may be milked from the $\mathrm{Sr}^{90}$ on the colum or the $\mathrm{Sr}^{90}$ may be stripped from the colum for further purffication. Treatment of Resin

The resin used was Dowex $-50,100-200$ mesh. The resin was air-dried and then washed with $6 \mathrm{~N} \mathrm{HCl} \mathrm{(Note} \mathrm{1)} \mathrm{and} \mathrm{water.} \mathrm{The} \mathrm{particles} \mathrm{which} \mathrm{floated}$ in the solution after 15 minutes were decanted off. $125 \mathrm{~mm} 0 . D$. glass tube was filled with resin to a height greater than $10 \mathrm{~cm}$ by slurrying the resin in water, pouring it into the column, and allowing the resin to settle onto a glass wool plug without flow of water. After the desired beight of resin was reached, the resin bed was suspended in water and allowed to settle. The colum was washed with about $200 \mathrm{ml}$ of water, until the pH of the effluent was the same as that of the influent, then with $400 \mathrm{ml}$ of ammonium citrate, $\mathrm{pH}=6.0$, to convert the column to the ammonium form. After washing with $400 \mathrm{ml}$ of water, it was ready for use.

Passage of Water Through Resin Bed

The water sample was filtered and passed through the colum at a 


\section{PROGNORL $29\left(\right.$ Cont $\left.1 d_{0}\right)$}

rate of about 1 liter per hour. The solution was discarded after the volume had been measured. Purification of $\mathrm{Sr}^{90}$

To strip the Sr $90-\mathrm{Y}^{90}$ off the column, $400 \mathrm{ml}$ of ammonium citrate (prepared by adjusting the $\mathrm{pH}$ of a $5 \%$ solution of citric acid to 6.0 with $\mathrm{NH}_{4} \mathrm{OH}$, and then adding $5 \mathrm{~m}$ of formaldehyde per liter as preservative) were passed through the column at a flow rate of about 1 liter per hour. Strontium carrier was added and the solution heated. Thirty ml saturated $\mathrm{H}_{2} \mathrm{C}_{2} \mathrm{O}_{4}$ were added and the $\mathrm{SrC}_{2} \mathrm{O}_{4}$ digested for at least 2 hours, (frequently overnight) to enable precipitation to be complete. The solution was decanted through a filter and the precipitate slurried into a centrifuge tube. This was centrifuged and the precipitate on the filter paper washed through a hole punctured in the paper into the tube, which was centrifuged again.

After the precipitate had been centrifuged down, it was dissolved in $\mathrm{HNO}_{3}$ with heating. The tube was cooled in an 1 ce bath and about $30 \mathrm{ml}$ of fuming $\mathrm{HNO}_{3}$ added. After sitting for a few minutes in the ice bath, the $\mathrm{Sr}\left(\mathrm{NO}_{3}\right)_{2}$ was centrifuged off and washed with $15 \mathrm{ml}$ fuming $\mathrm{HNO}_{3}$ (Note 2).

The precipitate was dissolved in $20 \mathrm{ml} \mathrm{H}_{2} \mathrm{O}$ and 10 drops Fe carrier ( $10 \mathrm{mg} \mathrm{Fe} / \mathrm{ml}$ ) were added, if necessary. The solution was heated nearly to boiling, made basic with $\mathrm{NH}_{4} \mathrm{OH}$ from a freshly opened bottle and the $\mathrm{Fe}(\mathrm{OH})_{3}$ centrifuged off (Note 3). The time of $\mathrm{Fe}(\mathrm{OH})_{3}$ separation was recorded as zero time for $\mathrm{Y}^{90}$ growth.

The solution was neutralized with $6 \mathrm{~s} \mathrm{HNO}_{3}$ and $2 \mathrm{ml} 6 \mathrm{M} \mathrm{N} \mathrm{H}_{4} \mathrm{OAc}$ and $1 \mathrm{ml} 6 \mathrm{M}$ HOAc added. Fifteen drops of Ba carrier (50 mg Ba/ml) were added, the solution heated nearly to boiling, and $1 \mathrm{ml} 1.5 \mathrm{~N} \mathrm{~K}_{2} \mathrm{CrO}_{4}$ added dropwise with stirring. The $\mathrm{BaCrO}_{4}$ was allowed to digest for a few minutes and then decanted through a $\$ 42$ Whatman filter paper into a $150 \mathrm{ml}$ beaker. Two $\mathrm{ml}$ $\mathrm{NH}_{4} \mathrm{OH}$ were added and the sclution heated. Five $\mathrm{ml}$ of $\left(\mathrm{NH}_{4}\right)_{2} \mathrm{CO}_{3}$ were added and the $\mathrm{SrCO}_{3}$ digested for a short time. This was filtered on a weighed 


\section{PROCHDURL 29 (Oant 'd.)}

fritted glass filter, dried at $110^{\circ}$ for 15 mtnutes, cooled, and weighed. The $\mathrm{SrCO}_{3}$ was then dissolved in $2 \mathrm{ml} 6 \mathrm{M} \mathrm{HCl}$ and washed into a glass vial to be stored for 90 growth and milking.

Secaration of $5 \times 90-190$

The $\mathrm{Y}^{90}$ was milked from the $\mathrm{sr}^{90}$ on the column by passing through the colum $50 \mathrm{ml}$ citric actd $(\mathrm{pH}=2.0$ ) and $350 \mathrm{ml}$ citric acid ( $\mathrm{pH}=3.8$ ), combining the washes in a beaker (Note 4). Yttrium carrier was added, the solution heated, and $30 \mathrm{ml}$ saturated $\mathrm{H}_{2} \mathrm{C}_{2} \mathrm{O}_{4}$ added. The solution was allowed to cool and then filtered. If there were not calciom present, this precipitate was ignited and the $\mathrm{I}_{2} \mathrm{O}_{3}$ weighed and mounted for counting. If calcium were present, the $\mathrm{YPO}_{4}$ separation would have to be done after igntion.

Notes:

1. The HCI removes traces of impurities wich are present in quantities sufficient to imoart a color to the initial washes.

2. If calctum is present, the concentration of the fuming $\mathrm{HM}_{3}$ should be not over $75 \%$.

3. It is necessary to use fresh $\mathrm{NH}_{4} \mathrm{OH}$ to prevent the precipitation of $\mathrm{SrCO}_{3}$ by $\mathrm{CO}_{2}$ picked up from the atmosphere.

4. The citric acid, $\mathrm{pH}-2.0$, is passed through the columen to reduce the $\mathrm{pH}$ rapidly $s 0$ as not to elute the $\mathrm{Sr} 90$. 


\section{PROCEDURE 30}

\section{STRONTIUM}

Source - W. B. Silker in U. S. Atomic Energy Commission, Report HH-55117, May 20, 1958.

Three types of samples were analyzed for strontium-90: soil, vegetation, and animal bones. A cursory investigation of soil from the arid region of the Hanford Reservation indicated that about 75 per cent of the radiostrontium was held in the top one-half inch of soil. This surface layer was subsequently samplea for the present study. Vegetation samples were limited, with a few exceptions, to grasses of different varieties. No attermt was made to differentiate the variety or age of the vegetation sample. Bones of animals, primarily rabbit femurs, were collected at various locations throughout the Hanford Reservation. Rabbits should be extremely good indicators of localized contamination, as their forage range is limited to approximately one square mile $\boldsymbol{T}$, and as vegetarians they will tend to furnish an integrated sample of the diet in their immediate environment.

\section{SAMPLE PRETREATYENT}

Samples were pretreated by methods which were similar to those employed by the Chicago Sunshine Group. 78 Detailed procedures are appended. The available calcium and strontium was leached fror soil sainples by the ammonium acetate method. $\mathbf{7 8}$ Vegetation samles were reducea by wet ashing with nitric acid. The residual material was baked on a hot plate and then muffled at $600 \mathrm{C}$ for two to four hours. Sample solution was accomplished by digestion in dilute nitric acid. The residual material from the first few samples was fused with sodium carbonate, dissolved, and upon analysis was found to contain no strontium-90. This residue was subsequently discarded. Animal bones were placed directly into a muffle furnace and ashed for two to four hours at $600 \mathrm{C}$ and then dissolved in nitric acid. 


\section{PROGSDURE 30 (Cont'd.)}

\section{CALCIUM AMLISIS}

Whenever possible, the calcium concentration was determined by precipitation of the alkaline earths as axalates, which were oven-dried at $120 \mathrm{C}$ and weighed. The oxalates were then muffled to the oxide at $800 \mathrm{C}$ and reweighed. When the oxide to oxalate ratio corresponded very nearly to the molecular weights of calcium oxide and calcium oxalate monohydrate, the calcium was taken as 0.715 times the oxide weight. When this ratio was not obtained an aliquot of the acid solution of the oxide was taken for calcium analysis. This method for calcium analysis involved the precipitation of the oxalate from slightly acid solution. The oxalate was dissolved in dilute sulfuric acid and titrated with potassium permanganate.

\section{STROMTIUA SEPARATION}

The presence of rare earth fission products which follow yttrium necessitated chemical separation of strontium, which was then reserved to allow buildup of yttrium-90. Strontium was separated a modification of the method of Glendenin 79 which employed initial barium and strontium isolation by precipitation as nitrates with fuming nitric acid. Calcium decontamination was made by washing the nitrate precipitate with anhydrous acetone. After an iron hydroxide scavenge, barium was precipitated as the chromate, and strontium was separated as strontium carbonate. The carbonate was weighed for jield determination and reserved for buildup of yttrium-90.

\section{YTTRIUM EXTRACTION}

The need for the highest nossible sensitivity for yttrium-90 measurement made a carrier separation undesirable because carrier would decrease the effective counting efficiency of the emitted beta particles. Solvent extraction of yttrium-90 from the dissolved strontium salt offered a technique for the carrier-free isolation of yttrium-90, thus eliminating the counting error introduced by self absorption of the yttrium-90 beta particles. Yttrium was extracted from acetate-buffered solutions with thenoyltrifluoro- 
acetone in benzene according to the procedure described by Perkins 00 The decay of yttrium-90 from all samples was followed for several half-lives, and with only three exceptions the yttrium-90 was free from contemination.

\section{Preparation of Bone Samples}

1. Place a sample of bone, not exceeding thirty grams, in a tared Vycor evaporating dish.

2. Wuffe the sample at $600 \mathrm{C}$ for tro hours, or until all of the organic material is destroyed.

3. Cool and reweigh the dish and sample, and record the weight of ash.

4. Dissolve the bone ash in 4 N nitric acid, and dilute with water to volume in a suitable volumetric nask.

5. Reserve an aliquot of the sample for calcium determination, and proceed with the strontium determination with the remainder.

\section{Preparation of Vegetation Samples}

1. Place the regetation sample in a drying oven at $110 \mathrm{C}$ for forty-eight hours.

2. Pass the sample through a Wiley mill.

3. Weigh a $100 \mathrm{~g}$ sample and place it in a $2000 \mathrm{ml}$ beaker.

4. Ldd sufficient $8 \mathrm{~N}$ nitric acid to cover the sample, and evarorate to dryness on a hot plate at low heat. Raise the temperature of the hot plate to high heat, and bake the sample.

5. Transfer the sample to a tared $400 \mathrm{ml}$ Vycor evaporating dish and maffle at $400 \mathrm{C}$ for two hours, or until the organic matter is destroyed.

6. Reweigh the dish plus sample, and record the ashed weight.

7. Digest the ash with $200 \mathrm{ml} 3 \underline{N}$ nitric acid by boiling on a hot plate for five minutes.

8. Cool, centrifuge, and decant the supernatant liquid into a liter beaker.

9. Repeat steps 7-8 and discand the residue.

\section{Extraction of Exchangeable Calcium and Strontium in Soils}

1. Crush the air-dry sample and pass the sample through a $2 \mathrm{~mm}$ sieve. 


\section{FROCEDURE 30 (Cont 'd.)}

2. Place $500 \mathrm{~g}$ of the prepared sample in a four liter beaker and add sufflcient neutral normal ammonium acotate to cover.

3. Stir well and let stand overnight.

4. Filter the sample through two thicknesses of coarse filter paper, and leach the sample with amonium acetate until a total of two liters of leachate is obtained.

5. Transfer the leachate to a four liter beaker and evaporate to drymase.

6. Bake the residue until dehydration of the salt is complete.

7. Loosen as mach of the dry residue as possible with a spatula and transfer to an evaporating dish.

8. Place the evaporating dish in a muffle at about $150 \mathrm{C}$, heat to $600 \mathrm{C}$, and hold this temperature for about one hour.

9. To the small amount of residue remaining in the beaker, add $200 \mathrm{ml}$ of water, and $10 \mathrm{ml}$ of $30 \%$ hydrogen peroxide.

10. Cover and boll for 15-20 minutes.

11. Combine the ashed residue and percoxide treated residue.

12. Idd small portions of hydrochloric acid with stirring until all of the carbonates are decomoosed; add 10-15 ml in excess.

13. Heat the solution to about $90 \mathrm{C}$ and add $1: 1$ ammonium hodroxide with stirring until a faint odor of ammonia persists.

14. Boil for 2-3 minutes to coagulate the precipitate and filter through coarse filter paper.

15. Wash the filter with 200 ml of a hot $2 \%$ ammonium chloride solution.

16. To the combined filtrate and wash, add 20 drops of methol red indicator and acidify with hydrochloric acid; add 10-15 $\mathrm{ml}$ in axcess.

17. Heat to $90 \mathrm{C}$ and add 25 grams of cxalic acid.

18. Continue heating for 2-3 minutes and slowly add 1:1 ammonium hydroxide until the solution turns a light jellow.

19. Digest at $90-95 \mathrm{C}$ for $1-2$ hours. 


\section{PROCFDURE 30 (Cont'd.)}

20. Collect the oxalate precipitate in a Gooch crucible.

21. Determine calcium and strontium in the oxalate precipitate.

\section{Strontium Separation}

1. Place the acid extract in a beaker of suitable size, and add $40 \mathrm{mg}$ of strontium carrier and $10 \mathrm{mg}$ of barium carrier.

2. Neutralize the sample with $12 \mathrm{~N}$ sodium hydroxide.

3. Heat to boiling.

4. Add $40 \mathrm{ml}$ of saturated sodium carbonate with stirring.

5. Allow the sample to cool for thirty minutes.

6. Centrifuge.

7. Discard the supernatant liquid.

8. Dissolve the carbonate precipitate in a minimum of concentrated nitric acid.

9. Add fuming nitric acid until precinitation starts.

10. Cool for one minute with running tao water and centrifuge.

11. Suspend the well drained precipitate in $20 \mathrm{ml}$ of anhydrous acetone. Cool for one minute with running tap water and centrifuge.

12. Dissolve the precipitate in $6 \mathrm{ml}$ of water and add $18 \mathrm{ml}$ of fuming nitric acid. Cool for one or two minutes with running tap water. Centrifuge and discard tre supernatant liquid.

13. Dissolve the precipitate in $10 \mathrm{ml}$ of water, add $2-3 \mathrm{mg}$ of iron carrier and precipitate iron hydroxide by addition of $6 \underline{\mathrm{N}}$ ammonium hydroxide.

14. Centrifuge and decant the supernatant liquid into a clean centrifuge tube.

15. Neutralize the solution to the phenolphthalein end point with 6 N nitric acid, add $1 \mathrm{ml}$ of $6 \underline{\mathrm{N}}$ acetic acid and $2 \mathrm{ml}$ of $6 \underline{\mathrm{N}}$ ammonium acetate. Heat the solution nearly to boiling and add $1 \mathrm{ml}$ of $1.5 \mathrm{~N}$ scodium chromate drop by drop with stirring. Continue stirring for about one minute and centrifuge.

16. Decant the supernatant liquid into a clean centrifuge tube, and add $5 \mathrm{ml}$ 


\section{PROCWDUR 30 (Oont'd.)}

of saturated sodium carbonate with stirring. Centrifuge and discard the supernatant liquid.

17. Wash the precipitate twice with water and once with ethanol.

18. Transfer the precipitate to a tared one inch counting dish with ethanol.

19. Dry under an inira-red heat lamp, weigh and reserve for build-up of yttrium-90.

\section{Yttrium-90 Butraction Procedure}

1. To a $60 \mathrm{ml}$ separatory funnel, add $10 \mathrm{ml}$ of TTS solution (10 $\mathrm{g}$ thenoyltrifluoroacetone in $100 \mathrm{ml}$ of benzene). $5 \mathrm{ml}$ of $0.5 \mathrm{~N}$ nitric acid, and shake mechanically for five minutes. Discard the aqueous phase.

2. Dissolve the strontium precipitate in $5 \mathrm{ml}$ of $0.5 \mathrm{~N}$ nitric acid and transfer the solution to the separatory funnel.

3. Idd $10 \mathrm{ml}$ of buffer solution ( $0.5 \underline{M}$ Sodium acetate, $0.1 \underline{M}$ acetic acid) and extract for 10 minutes. Discard the aqueous phase.

4. Extract five minutes each with two $10 \mathrm{ml}$ portions of 0.1 sodium acetate0.1 acetic acid.

5. Back extract the Jttrium-90 into $10 \mathrm{ml}$ of 0.1 N nitric acid.

6. Evaporate the aqueous phase to dryness on a one inch stainless steel counting dish and measure the yttrium-90 disintegration rate.

\section{PROCEDURE 31}

\section{STRONTIUM}

Source - A. S. Goldin, R. J. Velten, and G. W. Frishkorn in Anal. Chem. 3l, 1490 (1959).

The radioactive isotopes strontium- 89 and strontium -90 are determined in a wide variety of environmental samples. Strontium-90 is determined by beta-counting the daughter activity, yttrium-90, after extraction into 2-thenoyltrifluoroacetone reagent. Total radioactive strontium is determined by beta-counting a strontium carbonate precipitate. The method includes procedures for treating different types of material 


\section{PROG SDURT 31 (Cont 'd.)}

and removing common interferences.

The basic procedures for the determination of radiostrontium were developed for use in samples of fresh water. Other samples require pretreatment to convert them to a form which will fit into this scheme of analysis. These procedures differ from ordinarily used procedures in several ways. A large amount of strontium carrier ( 1 or 2 moles) is used, so that solubility and transfer losses will amount to a smaller percentage of total strontium. Second no attempt is made to obtain a pure, weighable strontium precipitate for chemical yield determination - chemical yield when required is determined by flame spectroscopy. Third, no carrier yttrium is used. This eliminates the possibility of radioactivity in the yttrium salt and also permits counting from a weightless yttrium extract, eliminating the troublesome correction for self-absorption.

Determination of Strontium -90 in Fresh Water. The sample containing $4 \mathrm{ml}$ of $1 \mathrm{~N}$ carrier strontium is made strongly alkaline and brought to boiling, and sodium carbonate is added to precipitate strontium carbonate. The collected precipitate is dissolved in hydrochloric acid, neutralized with ammonia to a methyl orange end point, and buffered at $\mathrm{pH} 5$. Barium is added, followed by potassium chromate to precipitate barium chromate, which is discarded. Strontium is reprecipitated as carbonate and aggin brought into solution with hydrochloric acid. Ferric iron is added and precipitated with ammonia and the precipitate is discarded. Zirconium and rare earth (usually cerium or lanthanum) carriers are added and the warm solution is acidified and then made basic with ammonia. The precipitated rare earth and zirconium hydroxides are discarded and the strontium is again concentrated by precipitation with sodium carbonate.

The strontium carbonate, thus obtained is stored overnight or longer for ingrowth of the yttrium daughter of the strontium-90. The length of this ingrowth period depends on the strontium-90 content expected; it is shorter for samples of high activity. At the lowest levels an ingrowth period 


\section{PROCIDURE 31 (Gentid.)}

of 2 weeks is allowed, during which the yttrium-90 reaches $97 \%$ of its final equilibrium value. For an ingrowth period of only 18 hours, on the other hand, the yttrium-90 reaches about $18 \%$ of the equilibrium value.

After ingrowth of yttrium, the strontium carbonate precipitate is dissalved with hydrochloric acid, neutralized to mathyl orange with ammonia, and buffered at $\mathrm{pH} 5$. The yttrium is extracted into 2-thenoyltrifluoroacetone solution. After the organic phase is washed with water buffered at $\mathrm{pH} 5$, the yttrium-90 is stripped by extraction with I hydrochloric acid. The hydrochloric acid extract is evaporated on copper planchets, heated thoroughly to destroy residual organic matter, and counted, correcting for decay of the yttrium-90 between its extraction and the counting time.

In this procedure the decontamination factor for contaminating isotopes is about 104. Typical results for a number of common fission products chosen as representative are given in Table 1.

TABLE 1. YIELD OF CONTAMINATING ISOTOPES

\begin{tabular}{|c|c|c|c|}
\hline \multirow{2}{*}{ Isotope } & \multirow{2}{*}{$\begin{array}{l}\text { Amount } \\
\text { Added, } \\
\text { C.P.M. }\end{array}$} & \multicolumn{2}{|c|}{ Amount Recovered } \\
\hline & & C.P.K. & $\%$ \\
\hline $\begin{array}{l}\mathrm{Sr}^{89} \\
\mathrm{Cs} 137 \\
\mathrm{Ce} 14 \mathrm{~W} \\
\mathrm{ZrNb} 95\end{array}$ & $\begin{array}{r}51,000 \\
178,000 \\
584,000 \\
585,000\end{array}$ & $\begin{array}{l}19 \\
18 \\
39 \\
51\end{array}$ & $\begin{array}{l}0.04 \\
0.01 \\
0.007 \\
0.009\end{array}$ \\
\hline
\end{tabular}

Chemical yields for strontium range from 70 to $100 \%$, with a mean of approximately $85 \%$. Recovery of yttrium in the solvent extraction is greater than $95 \%$.

Total Radiostrontium in Fresh Water. The strontium is collected by precipitating $2 \mathrm{ml}$ of $1 \mathrm{~N}$ carrier strontium as carbonate and treated with concentrated (70\%) nitric acid to remove calcium and megnesium imourities. Thirty milliliters of concentrated nitric acid are used in this treatment. The mixture is digested in a warm water bath with occasional stirring for about 10 minutes and cooled in an ice bath for 
5 minutes, after which the precipitated strontium nitrate is separated and collected by centrifugation. (In soft waters where the additional weight of the carbonate precipitate would be of no concern, this nitric acid treatment may be omitted, leaving the calcium in the final carbonate precipitate.) The strontium nitrate (or carbonate) is redissolved and purified by barium chromate precipitation and iron and zirconiun-rare earth hydroxide scavenging as above. The purified strontium is precipitated finally as strontium carbonate, transferred to counting dishes, and counted directly to obtain total radiostrontium content. Strontiun- 89 is calculated by difference between the total radiostrontium value and the strcntium-90 activity.

Average chemical yield is $85 \%$. Because strontium- 89 is determined by difference, the error is dependent on the error of the strontium-90 determination and on the relative amounts of strontium-90 and strontium-89.

\section{Strontium-90 and Total Radiostrontium in Salt and Brackish}

Waters. The determination of radiostrontium in salt and brackish waters is complicated by the mass of precipitate obtained. In salt water this is largely due to the magnesium which is present in sea water to the extent of 1.27 grams per kilogram. If the $\mathrm{pH}$ is adjusted to minimize the precipitation of magnesium carbonate, the precipitation of strontium carbonate is not quantitative, the loss amounting to about 10\% when 1 mmole of carrier strontium is used. Accordingly, the carbonate precipitation was carried out from strongly alkaline solution, a preliminary separation of magnesium being made to facilitate this operation.

The heated sample containing strontium carrier is treated with ammonia and alcoholic 8-quinolinol to precipitate magnesium. This precipitate is filtered off, washed thoroughly, and discarded, the washings being added to the flltrate. Sodium hydroxide and sodium carbonate are added to the heated filtrate to precipitate strontium, calcium, and other salts. The 


\section{PROGEDURE 31 (Cont'd.)}

washed precipitate is collected and thoroughly dried, after which it is treated with concentrated nitric acid to remove calcium from the precipitated strontium nitrate. A second nitric acid treatment is usually required for adequate removal of calcium. The strontium is purifled by the standard barium chromte and hydroxide precipitations, after which strontium carbonate is precipitated for determination of total radiostrontium. After total radiostrontium activity has been counted, the strontium carbonate precipitate is stored for jttrium ingrowth and the yttrium is extracted and back-extracted as described above.

Loss of strontilum in the mesesium precipitate is only about $2 \%$ and precipitation from the sodium hydroxide-sodium carbonete solution is quantitative. Over-all chemical recovery is about $85 \%$, most of the loss being in the nitric acid treatments.

Determination of Radiostrontium in Soils and Sludges. The sample is converted to ash in 3 maffle furnace and an aliquot of 1 to 50 grams is taken for analysis. After addition of strontium and barium carriers and drying, the ash is mixed with 5 times its weight of sodium hydroxide and fused in a nickel crucible. Sodium carbonate is added to the welt and the mixture is heated again. The fusion mixture is taken up in hot water to complete disintegration of the solid, and centrimged; the supernatant is discarded. The residual solid is dissolved in hydrochloric acid and the strontium precipitated as carbonate by addition of ammonia and sodium carbonate. Strontium is purifled by nitric acid treatment, barium chromate precipitation, and hydroxide scavengings before counting for total radiostrontium content or separation of yttrium-90. In these samples, nitric acid treatmont usually is necessary, even if only strontium-90 is to be determineá.

If only leachable radiostrontium is desired, the original sample is extracted several times with hot $6 \mathrm{M}$ nitric acid. After addition of carrier, the acid is neutralized and the strontium precipitated with 
PROCEDURE $3 I$ (Cont'd.)

carbonate, which is then treated in the same way as the carbonate obtained after fusion.

Radiostrontium in Biological Materials. The sample is converted to ash, usually in a muffle furnace. For some samples, however, wet ashing with nitric acid followed by an equal-volume mixture of nitric and perchloric acids my be preferred. A suitable aliquot is taken, dissolved in hydrochloric acid, and evaporated to near dryness. The chlorides are converted to nitrates by evaporation with nitric acid and strontium nitrate is precipitated from concentrated nitric acid. Lfter a second precipitation from nitric acid, the precipitate is dissolved in water and made alkaline with ammonia to test for completeness of phosphate removal. Any precipitate (indicative of unremoved phosphate) is digested with sodium carbonate to convert the phosphate to carbonate. This is dissolved in acid, warmed to drive off carbon dioxide, and again made alkaline with ammonium hydroxide. If a precipitate forms, it is discarded. Sodium carbonate is added to the combined strontium-containing supernatants to precipitate the strontium as carbonate. This precipitate is collected and purified by barium chromate precipitation and hydroxide scavenging. In all cases with biological samples, treatment with nitric acid is necessary to prevent phosphate inter ference. 
FROCBDURB 32

\section{STROMIUU AND BMRIUY}

Source - Determination of Strontium and Erium Activities in Fission", I. B. Glendenin, Paper 236 in Radiochemical Studies: The Fission Prochecte", edited by C. D. Coryell and N. Sugarman, McGram-Hill Book

Co., Inc., New Yark, 1951. It is besed on report CN-1312, datod Kay 15, 1945.

\section{IMTRODUCTION}

The precipitation of $\mathrm{Sr}\left(\mathrm{HO}_{3}\right)_{2}$ and $\mathrm{Br}\left(\mathrm{HO}_{3}\right)_{2}$ fuming $\mathrm{HrO}_{3}$ is a classical mothod for the separation of strontiun and barium fron fissionproduct nixtures.8I Although the mothod is fairly specific for strontium and barium, it has been known for some time that conterinating activities we be present even after several reprecipitations.82-84 In order to rewove this contamination, a $\mathrm{Fe}(\mathrm{OH})_{3}$ scavenging precipltation is ade aftar a single reprecipitation of the strontium and barium nitrates. The barium is then separated from strontiun as the chromte in a buffered $\mathrm{HC}_{2} \mathrm{H}_{3} \mathrm{O}_{2}$ solution (Of $\mathrm{pH} \mathrm{5),} \mathrm{in} \mathrm{which} \mathrm{strontium} \mathrm{is} \mathrm{soluble,} \mathrm{and} \mathrm{converted} \mathrm{to} \mathrm{BnCl}_{2} \cdot \mathrm{H}_{2} \mathrm{O}$ for added purification trom strontiun and for weighing, 85 the strontin is isolated from the acotic acid-chromate solution as $\mathrm{SrC}_{2} \mathrm{O}_{4} \cdot \mathrm{H}_{2} \mathrm{O}$ and is weighed as such after an alcohol-ether washing and racum desiccation. The preciptation of the $\mathrm{SrC}_{2} \mathrm{O}_{4} \cdot \mathrm{H}_{2} \mathrm{O}$ is made in an amoniacal solution to prevent the reduction of the chromate to $\mathrm{Cr}$ (III) bo coralic acid and the subsequent coprecipitation of $\mathrm{Cr}$ (III) with the $\mathrm{SrC}_{2} \mathrm{O}_{4} \cdot \mathrm{H}_{2} \mathrm{O}$.

The procedure previcusly emplojed 83 was somewhat longer, involving added reprecipitations of the alkaline-oarth nitrates and an added $\mathrm{BaCrO}_{4}$ separation from the strontium fraction. These unnecessary operations have been deleted from the procedure. The simplified method is given below.

\section{FREPARATION AND STANDARDIZATION OF CARRIER}

Strontiun Carrier. Dissolve $24.1 \mathrm{~g}$ of $\mathrm{Sr}\left(\mathrm{NO}_{3}\right)_{2}$ in water and dilute to 1 liter. Pipet $5 \mathrm{ml}$ of carrier solution into a beaker and add about $30 \mathrm{ml}$ of $\mathrm{H}_{2} \mathrm{O}$. Idd $5 \mathrm{ml}$ of saturated cxalic acid and heat nearly to boiling. Add $2 \mathrm{ml}$ of conc. $\mathrm{NH}_{4} \mathrm{OH}$ drop by drop with constant atirring.

Allow to stand for about 10 min in cool tap water with occasional 
PROCEDURE 32 (Cont 'd.)

stirring. Filter quantitatively on a weighed sintered-glass crucible with suction. Wash three times with 5 al of hot $\mathrm{H}_{2} \mathrm{O}$ containing a few drops of $\mathrm{NF}_{4} \mathrm{OH}$, three times with 95 per cent ethanol, and three times with 5 ml of ether, rinsing down the inside of the crucible with each washing. Wipe the outside of the crucible with Rleenex or a lintless cloth and place in a vacuum desiccator. Evacuate for 2 min. Weigh as $\mathrm{SrC}_{2} \mathrm{O}_{4} \cdot \mathrm{H}_{2} \mathrm{O}$ and repeat the desiccation until the weight is constant to $0.2 \mathrm{mg}$.

\section{PROCEDURE}

Step 1. To 1 to $5 \mathrm{ml}$ of neutron-irradiated uranyl nitrate in a 50ml centrifuge tube add 2 ml each of barium and strontium carrier and then $30 \mathrm{ml}$ of fuming $\mathrm{HNO}_{3}$. Cool (under running tap water), stirring for 1 to 2 min, and centriruge.

Step 2. Dissolve the precipitate in about 2 ml of $\mathrm{H}_{2} \mathrm{O}$ (Note 1), reprecipitate with 15 ml of fuming $\mathrm{HNO}_{3}$, and centrifuge.

Step 3. Dissolve the precipitate in 5 to $10 \mathrm{ml}$ of $\mathrm{B}_{2} \mathrm{O}$, add $5 \mathrm{mg}$ of fron carrier, and precipitate $\mathrm{Fe}(\mathrm{OH})_{3}$ with about $2 \mathrm{ml}$ of $6 \mathrm{M} \mathrm{NH} 4 \mathrm{OH}$. Centrifuge and discard the $\mathrm{Fe}(\mathrm{OH})_{3}$.

Step 4. Neutralize the supernatant solution with $6 \mathrm{M}^{\mathrm{NNO}} 3$ and add $1 \mathrm{ml}$ of $6 \mathrm{M} \mathrm{HC}_{2} \mathrm{H}_{3} \mathrm{O}_{2}$ and $2 \mathrm{ml}$ of $6 \mathrm{H} \mathrm{NH}_{4} \mathrm{C}_{2} \mathrm{H}_{3} \mathrm{O}_{2}$. Heat the solution nearly to boiling and add $1 \mathrm{ml}$ of $1.5 \mathrm{M} \mathrm{Na}_{2} \mathrm{CrO}_{4}$ drop by drop with stirring. Continue stirring for about 1 min and centrifuge (Note 2). Reserve the supernatant solution for strontium determination.

Step 5. Determination of Earium ${ }^{85}$ (Note 3). Wash the precipitate with $10 \mathrm{ml}$ of hot $\mathrm{H}_{2} \mathrm{O}$ and dissolve in 1 to $2 \mathrm{ml}$ of $6 \mathrm{M} \mathrm{HCl}$ (Note 4). Add $15 \mathrm{ml}$ of HCl-ether reagent, chill, and stir for 1 to $2 \mathrm{~min}$. Centrifluge and decant completely.

Step 6. Dissolve the precipitate in $1 \mathrm{ml}$ of $\mathrm{H}_{2} \mathrm{O}$. Reprecipitate with $15 \mathrm{ml}$ of HCl-ether mixture. Centrifuge and decant. Note the time.

Step 7. Transfer the precipitate to a weighed filter-paper disk (Note 5) on a small Hirsch funnel with three 5-ml portions of absolute 
PROCusure 32 (Cont'd.)

ethanal containing 3 to 5 drope of conc. BCI (Hoto 6). Filter with suction. Wagh three tims with 5-il portions of ether and such dry. Transfor the paper with the precipitate to a small watch glass and place in a vacum desiccetor. Brecuste for 2 min, relesse tho sucticn, and ovacuato again for 5 win. Finally, woigh the precipitate as $\mathrm{BCI}_{2} \cdot \mathrm{B}_{2} \mathrm{O}$ and mount for counting.

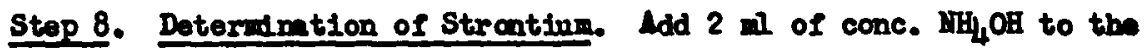
clear supernntant solntion from stop 4 , heat marly to bolling, and add 5 il of sat. ( $\left(\mathrm{MH}_{4}\right)_{2} \mathrm{C}_{2} \mathrm{O}_{4}$ slowly with stirring. Stir for 1 to 2 an and filter with ouction on a weighod papar (llote 5) in a all Hirsch funnal. Waoh throe times with 5 ml of $\mathrm{H}_{2} \mathrm{O}$, throe times with 5 ml of 95 per cont othanol, and three tives with 5 ml of other. Iransfer the paper containing the $\mathrm{SrC}_{2} \mathrm{O}_{4} \cdot \mathrm{H}_{2} \mathrm{O}$ to a amall watch glass and place in a vacuwe desicoator. Bracunte for $2 \mathrm{~min}$, release the suction, and evacunte again for 5 ain. Waigh the procipitete as $\mathrm{SrC}_{2} \mathrm{O}_{4} \cdot \mathrm{H}_{2} \mathrm{O}$ and nount.

Notes.

1. Heating $=\mathrm{y}$ be required in order to efrect complete colntion.

2. I fer drops of lerosol solution facilitates clean contriforation. If an particles of $\mathrm{BeCrO}_{4}$ ramin, the supermatent salntion should be filtered.

3. If coly strontiun is to be deterinined, the precipitate nas be discarded and the supernatant solution my be treated at cace as in stap 8 .

4. A sall residue (probably BaCl2) ay be formed, bet it can be Ignored.

5. The filter-paper diek is washed with ethanol and ether and dried in a verum desiccator under the conditicas of the procedure before the wolghing.

6. Barium chloride is appreciably soluble in absolute ethanol. The presence of the $\mathrm{HCl}$ represses the solubility and increases recovery. 


\section{PROCGEOURE 32 (Cont'd.)}

\section{DISCUSSION}

In the standardization of the strontium carrier, the $\mathrm{SrC}_{2} \mathrm{O}_{4} \cdot \mathrm{H}_{2} \mathrm{O}$ is precipitated by the method of the neutralization of an axalic acid solution with $\mathrm{NH}_{4} \mathrm{OH}$ rather than by the addition of $\left(\mathrm{MH}_{4}\right)_{2} \mathrm{C}_{2} \mathrm{O}_{4}$ to an ammoniacal solution, as is required in the analytical procedure. The precipitation is not performed by the latter method because it was observed in several instances that a precipitate of $\mathrm{SrCO}_{3}$ was formed in the hot ammoniacal solution (apparently by the absorption of $\mathrm{CO}_{2}$ from the atmosphere) before the addition of $\left(\mathrm{NH}_{4}\right)_{2} \mathrm{C}_{2} \mathrm{O}_{4}$. The presence of $\mathrm{SrCO}_{3}$ could lead to erratic results in the weighing; therefore, this method was discarded in favor of the method described above. The formation of $\mathrm{SrCO}_{3}$ in the analytical procedure has not been observed.

\section{PROCEDURE 33}

\section{STRONTIIY AND BARIOY}

Source - Mreparation of Carrier-Free Strontium and Barium Tracers by Use of Iead Nitrate and Lead Chronate Precipitations", L. B. Glendenin, Paper 238 in "radiochoricel Studies: The Fission Producta", edited to C. D. Carjell and N. Sugarman, McGraw-Hill Book Co., Inc., Now Iork, 1951. It is besed on repart CC-1050 dated November B, 1943.

\section{IMTRCDUCTION}

The precipitation of $\mathrm{Ba}\left(\mathrm{HO}_{3}\right)_{2}$ and $\mathrm{Sr}\left(\mathrm{HO}_{3}\right)_{2}$ by funing $\mathrm{HNO}_{3}$ is a classical mothod of separating barium and strontium from fiseion material.87,88 Since lead nitrate is $2180 \mathrm{highly}$ insoluble under these conditions, 89 the carrying of radiasctive berium and strontium on $\mathrm{Pb}\left(\mathrm{AO}_{3}\right)_{2}$ precipitated in this manner was tested. The mathod prored to be highly efficient for the separation of carrier-free barium and strontium fron the other fission procucts. On this sam basis the carrying of barium on $\mathrm{PbCrO}_{4}$ precipitated in a buffered $\mathrm{BC}_{2} \mathrm{H}_{3} \mathrm{O}_{2}$ solution, in which strontium is soluble, was studied, and the results showed that such a procedure separates barium tracer from strontiun tracer very efficiently. 
The $\mathrm{PbCrO}_{4}$, carryling the active barium is dissolved, the $\mathrm{CrO}_{4}^{--}$is reduced by $\mathrm{NaNO}_{2}$, the $\mathrm{Pb}^{\text {th }}$ and the $\mathrm{Cr}^{+3}$ are precipitated with $\mathrm{NH}_{4} \mathrm{OH}$ and the berium trecer is left in solution with $\mathrm{N}^{+}$, $\mathrm{NH}_{4}^{+}$, and $\mathrm{NO}_{3}^{-}$. The mother lignor from the $\mathrm{PbCrO}_{4}$ precipitation is freed of $\mathrm{CrO}_{4}-$ by the addition of excess $\mathrm{Pb}^{4}$, and the excess is removed with $\mathrm{H}_{2} \mathrm{~S}$. The strontiun is left in solution with the $\mathrm{Na}^{+}$and $\mathrm{NO}_{3}^{-}$ions.

\section{PROCEDURE}

Step 1. Idd $20 \mathrm{mg}$ of lead carrier to the fission-product material and eraporate the solution to about 2 al (Note 1 ). Add 15 to 20 al of funding EnNo3, cool, and stir occasionally for 3 to 5 min. Centrifuge, and discard the supernatant solution.

Stop 2. Dissolve the precipitate of $\mathrm{Pb}_{\left(\mathrm{HO}_{3}\right)_{2}}$ in 1 mil of $\mathrm{B}_{2} \mathrm{O}$ and reprecipitate with 10 to $15 \mathrm{ml}$ of tuming $\mathrm{HWO}_{3}$. Centrifuge as before, and discard the supernatant solution.

Step 3. Dissolve the $\mathrm{Pb}\left(\mathrm{HO}_{3}\right)_{2}$ in about $10 \mathrm{mil}$ of $\mathrm{H}_{2} \mathrm{O}$, add $10 \mathrm{mg}$ of lanthamm carrier, heat the solution nearly to bolling, and add $5 \mathrm{I} \mathrm{MH}$ (CO2-Iree) in slight excess with stirring to precipitate $\mathrm{Ia}\left(\mathrm{CH}_{3}\right.$ and $\mathrm{Pb}(\mathrm{OH})_{2}$. Centringe, and discard the precipitate.

Step 4. Neutralize the supernatant solution with $6 \mathrm{~N} \mathrm{HNO}_{3}$ and add 1 al of $6 \mathrm{~N} \mathrm{HC}_{2} \mathrm{H}_{3} \mathrm{O}_{2}$ and $4 \mathrm{ml}$ of $3 \mathrm{~N} \mathrm{H}_{4} \mathrm{C}_{2} \mathrm{H}_{3} \mathrm{O}_{2}$. Add $10 \mathrm{~m}$ of lead carrier, heat nearly to boiling, and add $1 \mathrm{ml}$ of $3 \mathrm{~N} \mathrm{Ka}_{2} \mathrm{CrO}_{4}$ drop by drop with atirring. Heat and stir for 2 min. Centrifuge, heat the supernatant solution, and add $10 \mathrm{mg}$ of lead carrier drop by drop with stimring. Centrifuge, and combine the $\mathrm{PbCrO}_{4}$ precipitate with the first precipitate (Hote 2). The supernetant solution is reservod for strontiun separation in step 10.

Step 5. Dissolve the combined $\mathrm{PbCrO}_{4}$ precipitates by heating with 2 to $3 \mathrm{mll}$ of $6 \mathrm{~N} \mathrm{HNO}_{3}$. Add $5 \mathrm{mg}$ of atrontium carrier and $10 \mathrm{ml}$ of $\mathrm{B}_{2} \mathrm{O}$. Heat nearly to boiling and neutralize with $6 \mathrm{~N}$ NH, OH. Add 1 al of $6 \mathrm{~N}$ $\mathrm{HC}_{2} \mathrm{H}_{3} \mathrm{O}_{2}$ and $4 \mathrm{ml}$ of $3 \mathrm{~N} \mathrm{NF}_{4} \mathrm{C}_{2} \mathrm{H}_{3} \mathrm{O}_{2}$. Heat the solution, add $10 \mathrm{mg}$ of lead carrier, and precipitate by adding 1 wl of $3 \mathrm{~N} \mathrm{Ne}_{2} \mathrm{CrO}_{4}$ drop by drop with 
stirring (Note 3). Centrifuge, and discard the supernatant solution.

Step 6. Dissolve the $\mathrm{PbCrO}_{4}$ in 2 to $3 \mathrm{ml}$ of $6 \mathrm{~N} \mathrm{HNO}_{3}$ and dilute to about $10 \mathrm{ml}$. Heat nearly to bolling, add $1 \mathrm{ml}$ of $\mathrm{IM} \mathrm{NaNO}_{2}$ drop by drop, and add $6 \mathrm{~N} \mathrm{NH}_{4} \mathrm{OH}\left(\mathrm{CO}_{2}-\right.$ free) in slight excess to precipitate $\mathrm{Cr}(\mathrm{OH})_{3}$ and $\mathrm{Pb}(\mathrm{OH})_{2}$. Centrifuge, and reserve the supernatant solution for barium

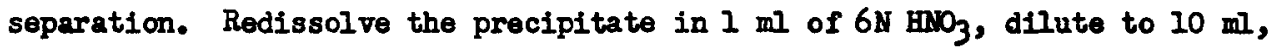
and reprecipitate with $6 \mathrm{~N} \mathrm{NH}_{4} \mathrm{OH}$. Centrifuge, and combine the supernatant solution with the supernatant solution from the first precipitation (Note 4 ).

Step 7. Neutralize the combined supernatant solntions with $6 \mathrm{~N} \mathrm{HC}_{2} \mathrm{H}_{3} \mathrm{O}_{2}$ and add $20 \mathrm{mg}$ of lead carrier, $2 \mathrm{ml}$ of $6 \mathrm{~N} \mathrm{HC}_{2} \mathrm{H}_{3} \mathrm{O}_{2}$, and $8 \mathrm{ml}$ of $3 \mathrm{~N} \mathrm{NH}_{4} \mathrm{C}_{2} \mathrm{H}_{3} \mathrm{O}_{2}$. Heat nearly to boiling and add $2 \mathrm{ml}$ of $3 \mathrm{~N} \mathrm{Naz} \mathrm{CrO}_{4}$ drop by drop with stirring. Centrifuge, and discard the supernatant solution (Note 5.)

Step 8. Proceed as in stop 6.

Step 9. Boil the combined solution containing the radioactive barium to expel $\mathrm{NH}_{3}$, and dilute to the desired rolume (Note 6).

Step 10. Heat the solution from step 4 and add 1 ml of $6 \mathrm{~N} \mathrm{HNO}_{3}$. Add drop by drop with stirring a solution of $0.5 \mathrm{~g}$ of $\mathrm{Pb}\left(\mathrm{NO}_{3}\right)_{2}$ dissolved in a few milliliters of $\mathrm{H}_{2} \mathrm{O}$. Heat and stir for $2 \mathrm{~min}$ (Note 7). Centrifluge, wash with 10 ml of hot $\mathrm{H}_{2} \mathrm{O}$, and discard the precipitate of $\mathrm{PbCrO}_{4}$. Heat the supernatant solution nearly to boiling and saturate with $\mathrm{H}_{2} \mathrm{~S}$. Centrifuge, and discard the $\mathrm{PbS}$ precipitate.

Step 1l. Evaporate the supernatant solution containing the radioactive strontium nearly to dryness. Add a few milliliters of conc. $\mathrm{HNO}_{3}$, again evaporate nearly to dryness, and make up to the desired rolume (Note 8).

Notes. 1. The fission-product material is the aqueous phase of etherextracted uranyl nitrate. With suitable modifications, other starting materials can be used.

2. The second precipitation of $\mathrm{PbCrO}_{4}$ is made to improve the recovery of barium.

3. The precipitation of $\mathrm{PbCrO}_{4}$ in the presence of strontium holdback 
carrier removes coprecipitated strontium. The additional lead is precipitated to recover barium more completely.

4. Chromic hydroxide and lead hydroxide are reprecipitated to recover ang barium that way have been coprecipitated.

5. Lead chromate (carrying barium) is again precipitated in a buffered solution to ensure the removal of strontium.

6. The barium tracer solution will contain $\mathrm{N}^{*}$, $\mathrm{HA}_{4}^{+}$, and $\mathrm{NO}_{3}^{-}$ions.

7. Lead is added to remove all the $\mathrm{Crg}_{4}^{--}$from solution. The amount of lead added is slightly more than the amount reguired.

8. The treatment with $\mathrm{HNO}_{3}$ removes $\mathrm{NH}_{4} \mathrm{C}_{2} \mathrm{H}_{3} \mathrm{O}_{2}$. The strontium tracer solution will contain $\mathrm{N}^{+}, \mathrm{H}^{+}$, and $\mathrm{NO}_{3}^{-}$ions.

\section{DISCUSSION}

The method was tested for separation by starting with aliquots of a 60-day-old fission-product concentrate prepared by an exhaustive etber extraction of urangl nitrate. The barium fraction 1 il isolated in the first $\mathrm{PbCrO}_{4}$ operation and reprecipitated once with $\mathrm{PbCrO}_{4}$ in the presence of strontium holdback carrier had an activity of 20,000 counts per wimte (c/m), or a 35 per cent yield of the value of 58,200 c/m determined by a conventional assay of the original concentrate. 88 The activity of the strontiun fraction was $370,000 \mathrm{c} / \mathrm{m}$, or a yield of 67 per cent of the value of $548,000 \mathrm{c} / \mathrm{m}$ in the original concentrate.

1 standard analysis ${ }^{88}$ of the barium fraction for strontiun activity showed the presence of $1,000 \mathrm{c} / \mathrm{m}$ of atrontium. The performance of the second $\mathrm{PbCrq}_{4}$ precipitation provided for in the procedure would undoubtedly lower this contamination considerably. In analysis of the strontium fraction for barium activity showed the presence of only $220 \mathrm{c} / \mathrm{m}$ of berium. Other fission species are probably removed to negligible values by the $\mathrm{Pb}\left(\mathrm{NO}_{3}\right)_{2}$ recrystallization followed by the $\mathrm{Pb}(\mathrm{OH})_{2}-\mathrm{Ia}_{2}(\mathrm{OH})_{3}$ precipitation, as shown by extensive studies on akaline-earth preparations by the closely analogous $(\mathrm{Ba}, \mathrm{Sr})\left(\mathrm{NO}_{3}\right)_{2}$ method described elsewhere. 88 
FROCIDURE 33 (Cont'd.)

It may be montioned that an attampt to carry $\mathrm{BCl}_{2}$ on $\mathrm{ChCl}$ precipitated from urapl nitrate with conc. BCI was unsuccess ful. This result was confireed by Hanilton, 90

\author{
PROCEDURE 34 \\ STRONTIUM AND BARIUM
}

Source - Lawrence B. Farabee in Oak Ridge National Laboratory Report ORN-1932, September, 1955.

\title{
PROCEDURE FOR THE RADIOCHEMICAL ANALYSIS OF STRONTIUM AND BARIUM IN HUMAN URINE
}

\begin{abstract}
AESTRACT
Ar analytical procedure for the determination of radioactive strontium and barium in large volumes of urine is described. The method is based on the preferential chelation of calcium over strontium using versene. This difference is greatest at a $\mathrm{pH}$ of 4.5 to 6.0. When a versenate chelate of the alkaline earths in a urine specimen, at a $\mathrm{pH}$ of 5.5 , is passed over a cation exchange colum all of the strontium and barium is adsorbed, whereas almost all of the calcium and about $1 / 2$ of the magnesium passes into the effluent as the chelate. The extraneous calcium and magnesium can be removed from the resin with a solution of citric acid and versene at a $\mathrm{pH}$ of 5.0. The sodium is removed with $0.5 \mathrm{~N} \mathrm{HCl}$, while the radioactive strontium and barium is eluted with $6 \mathrm{~N} \mathrm{HNO}_{3}$.
\end{abstract}

\section{EXPURIRENTAL}

PART I. THE AIKALINE PHOSPHATE PRECIPITATION

A short approach to a urinalysis procecure would utilize the urine direct wi thout preliminary concentration by precipitation. However, certain difficulties arise in using urine direct with ion exchange resins in a separation procedure. The high concentration of dissolved salts, as well as the variability in individual specimens, and the presence of organic matter 
in urine makes a preliminary precipitation an important adjunct in this procedure. Quantitative recovery of barium and strontium can be achiered by a basic phosphate precipitate from urine. Since these elenents do not form complexes with the organic materials prosent in urim, the procipitation can be carried out directly, thereby avoiding the laborious process of ashing the urine sample. This precipitate also serves two major purposes: (1) The separation of the above elements from sodium and potassium and (2) the separation from organic matter which is present in the urine sample.

\section{Procedure}

1. Idd concentrated hydrochloric acid (BCI) to a $1500 \mathrm{ml}$ urine sample to make the urine $0.1 \mathrm{~N}$ in $\mathrm{HCl}$ and yield a clean solution.

2. Heat the sample on a hot plate to a temperature of $85^{\circ}$ to $90^{\circ} \mathrm{C}$.

3. sdd $6 \mathrm{ml}$ of $6 \mathrm{M}$ phosphoric acid to provide an excess of phosphate to insure corplete precipitation of all calcium and magnesium.

4. Use an electric motor stirrer to provide vigorous stirring far the subsequent precipitation.

5. Add slowly $6 \mathrm{M}$ sodium hydraxide until a besic phosphate precipitate is visible. Continue the addition until the solution is basic to a pH of $E$ to 10. Universal pH paper can be used to determine the $\mathrm{pH}$ in this case. 6. The precipitate is allowed to settle for 2 hours or longer. 7. The supernatant liquid is decanted by suction to the larest possible level such that the precipitate is not disturbed. Discard the supernatant solution.

8. The remaining slurry is poured into a centrifuge cup. The precipitate is centrifuged at $1500 \mathrm{rpm}$ for 5 minutes. The supernatant liquid is decarited by suction and discarded. 


\section{PROGEDURE 34 (Cont'd.)}

\section{PAFT II. PREPARATION OF THE COLUMN}

(a) Description of colum system

Beds of 50-100 mesh Dowex $-50 \times 12$ resin are prepared in a Pyrex glass column $18.5 \mathrm{~cm}$ long and $1.8 \mathrm{~cm}$ inside diameter. The bottom is fitted with a one-way stopcock in a one-hole rubber stopper. Glass wool over the rubber stopper holds the resin bed. 16 inch Pyrex funnel fitted to the top of the glass colum with a rubber tubing serves as a reservoir for the feed and wash solutions.

(b) Preparation of the resin

New Dowex -50 resin is conditioned by several washings, alternately with 5 per cent $\mathrm{NaCl}$ and 5 per cent $\mathrm{HCl}$. During the conditioning process a considerable quantity of "fines" are removed. This is accomplished by stirring the resin sample in a large beaker filled with the conditioning solution. Most of the resin is allowed to settle, whereupon the liquid containing the "fines" is decanted. The resin is then converted to a sodium cycle with $5 \% \mathrm{NaCl}$. About $250 \mathrm{gms}$. of the resin is put into a Pyrex glass tube $4 \mathrm{ft}$. long and $2.5 \mathrm{~cm}$. diameter. Six liters of $5 \% \mathrm{NaCl}$ is then passed over the resin at a maximum flow rate $\left(4.7 \mathrm{ml} / \mathrm{min} / \mathrm{cm}^{2}\right)$. The resin is then emptied into a large beaker and washed free of $\mathrm{NaCl}$ with distilled water. The resin which has been used in urinalysis, can be re-useo by converting to the sodium cycle as described above.

For practical reasons, it is expedient to keep the amount of resin used to a minimum in order to reduce the volume of elutriant solutions and thereby reduce the time required to perform a single analysis. Experimentally it was found that 16.3 gms. of the above resin (air dried), or about $25 \mathrm{ml}$ by volume (wet form) was sufficient for an individual analysis. 


\section{PART III. OPERATION OF COLUMN}

\section{(a) Preparation of feed solution}

The alkaline earth phosphate precipitate can be dissolved in 10 to $20 \mathrm{ml}$ concentrated nitric acid. The resulting solution contains calcium, magnesium, phosphates, plus an indeterminate amount of sodium, potassium, ammonia ions, and organic material adsorbed on the gelatinous precipitate. The organic material can be destroyed by wet ashing in the presence of nitric acid and hdrogen peroxide. The inorganic residue is dissolved in 2 to $3 \mathrm{ml}$ of concentrated hydrochloric acid plus about $20 \mathrm{ml}$ distilled water. The solution is then diluted to about $800 \mathrm{ml}$ with distilled water.

This urinalysis procedure was designed primarily to analyze urine supernatant from a previous plutonium analysis in which $600 \mathrm{mg}$ of extra calcium had been added. The total calcium under these conditions was about $800 \mathrm{mg}$ while the magnesium was about 100 to $200 \mathrm{mg}$. When adsorbed on a cation exchanger of the size used in this procedure, such large quantities of alkaline earths would utilize most of the exchange capacity of the resin, thereby making the operation vulnerable to losses of strontium and barium. In order to circumvent the above difficulty, it was necessary to devise some way in which the amount of alkaline earths that were adsorbed on the resin could be held to a minimum. The greater complexing efficiency for calcium over strontium was used to develop a method whereby a large per cent of the calcium and some of the magnesium, being chelated with versene, would pass through the resin colum while while strontium and barium are adsorbed. The alkaline earths of the feed solutions are first chelated with versene at $\mathrm{pH}$ 10.5. At this pH a dye indicator can be used to determine the end point of chelation of the alkaline earths. The pH of the solution is chen reduced to 5.5 and put over the resin column. In 22 experimental runs using samples with added calcium as well as samples without, 94 to 97 per cent of the calcium passed through the column as a complex, while 36 to 
63 per cent of the magnesium alsc passed into the effluent. Losses of $\mathrm{Sr}^{89}$ tracer averaged from 0.11 to 0.19 per cent.

\section{Procedure}

1. The precipitate from Step 1,8 is dissolved in about $15 \mathrm{ml}$ concentrated nitric acid.

2. This solution is poured into the two liter beaker in which the original ohosohate precipitation was carried out.

3. The organic matter is destroyed by heating the solution, and by alternately acding conc. $\mathrm{HNO}_{3}$ and $30 \%$ hydrogen peroxide.

4. This is repeated until a white residue remains. The residue is then taken to dryness.

5. Remove the beaker from the hot plate and wash down the walls with about $20 \mathrm{ml}$ distilled water. Add 2 to $3 \mathrm{ml}$ concentrated hydrochloric acid and heat uritil the incrganic material is dissolved. The volume is diluted to $800 \mathrm{ml}$ with distilled water and the $\mathrm{pH}$ of the solution is checked in subsequent operations.

6. Idd I N sodium hydroxide until the pH is about 9.0.

7. Add 2 ml Eriochrome Black T*.

8. Add a solution of $7.5 \%$ technical Erade versene until the indicator changes from wine red to blue at $\mathrm{pH}$ 10.5. This ooint indicates comolete chelation of all calcium and magnesium.

9. Reduce the $\mathrm{pH}$ to 5.5 with concentrated hydrochloric acid. The final adjustment can be made with 1 iv HCl.

10. Pass this solution over the resin colum at a flow rate of not greater than $8 \mathrm{ml} / \mathrm{min} / \mathrm{cm}^{2}$.

11. Wash down the walls of the funnel with about $50 \mathrm{ml}$ distilled water.

12. Discard the effluents.

* Mix 0.5 gms. Eriochrome Black $\mathrm{T}$ and $4.5 \mathrm{gms}$. hydroxylamine hydrochloride. DAssolve in $100 \mathrm{ml}$ of alcohol and filter.

+ Dissolve 75 gms. tetrasodium ethylenediamine tetraacetic acid (technical grade) in about $800 \mathrm{ml}$ distilled water. Filter and dilute to one liter. 


\section{PROCINUR: 34 (Cont'd.)}

(b) Elution of Adsorbed Calcium and Magnesium from the Resin Colum The efficiency of versene to chelate the alkaline earths is reduced when the $\mathrm{pH}$ is lowered to 8.0 to 5.5 . Since the feed solution is put over the colum at a pH of 5.5, there will be some exchange of the cations between the feed solution and the resin because of this reduction. This indeterminate amount of calcium and magnesium that is adsorbed on the resin mast be removed without loss of strontium ana barium. The citrate complex would remove the alkaline earths in the following order: $\mathrm{M}_{\mathrm{g}}>\mathrm{Ca}>\mathrm{Sr}>\mathrm{Ba}$. Versene would be expected to remove calcium from the resin before the other alkaline earths. A combination of versene and citric acid at $\mathrm{pH} 5.0$ is a better elutriant than citric acid alone. This is due to the greater affinity for calcium by versene. There is no loss of $5 r^{89}$ even at twice the volume of elutriant necessary to remove all of the calclum and magnesium.

\section{Procedure}

1. Pass $800 \mathrm{ml}$ of a solution of one per cent citric acid and $0.75 \%$ versene over the resin column at a flow rate of $4 \pm 0.8 \mathrm{ml} / \mathrm{min} / \mathrm{cm}^{2}$ (10.93 $\mathrm{gms}$. citric acid monohydrate, $100 \mathrm{ml}$ of $7.5 \%$ versene, dilute to one liter and adfust the off to 5.0 with $6 \mathrm{M} \mathrm{NaOH}$ ).

2. Discard the effluent wastes.

(c) Removal of sodium from the resin colum

Since the Dowex -50 resin had been put on the sodium cycle in proparation for urinalysis, this sodiun mist be renored in ordar that the final eluate of the strontium and barium can be evaporated and prepared for counting without further chomical purification. Dilute acids will elute the monovalent sodium with no significant $108 s$ of $5 r^{89}$. In 22 experiental urinalyses, losses of $5 r^{89}$ averaged 0.22 per cent when $0.5 \mathrm{~N} \mathrm{HCI} \mathrm{was} \mathrm{used}$ to remore the sodium from the resin. 


\section{FROCEDURE 34 (Cont'd.)}

Procedure

1. Pass $800 \mathrm{ml}$ of $0.5 \mathrm{~N}$ hydrochloric acid over the resin colum at a flow rate of $4 \pm 0.8 \mathrm{ml}$ per minute per $\mathrm{cm}^{2}$.

2. Discard the effluent wash.

\section{ELUTION OF STRONTIUM AND BARIUN}

The strontium and barium can be eluted from the resin column with 200 ml $6 \mathrm{~N}$ nitric acid. This volume removes about 99.6 per cent of the strontium and barium.

\section{Procedure}

1. Pass $200 \mathrm{ml} 6 \mathrm{~N} \mathrm{HNO}_{3}$ over the resin at a flow rate of $2 \mathrm{ml} / \mathrm{min} / \mathrm{cm}^{2}$. 2. Catch the eluate in a $400 \mathrm{ml}$ beaker.

\section{PART IV. PREPARATION OF THE SAMPLE FOR COUNTIMG}

The eluate is evaporated on a hot plate to almost dryness at a temperature just below the boiling point. The residue is transforred to a counting dish*. The inorganic residue, which is mostly sodium and inert strontium and barium, will have a density of less than $1 \mathrm{mg} / \mathrm{cm}^{2}$, therefore self-absorption of the radiations by the sample should be nil.

Since the rare earth daughter products of $\mathrm{Sr}^{90}$ and $\mathrm{Ba}^{140}$ are chelated by the versene-citric acid wash, these radioactive products will be removed from the column by this wash. Therefore, the time of separation of these daughter products can be established for subsequent identification of the isotope by growth and/or decay measurements.

\section{Procedure}

1. Evaporate the nitric acid eluate to almost dryness on a hot plate.

2. Wash the contents into a $50 \mathrm{ml}$ beaker with distilled water. Clean the walls of the larger beaker with nitric acid and water. (This transfer to the

* This counting dish is made from a circular piece of type 304 stainless steel 1-3/4 inch diameter and 0.005 in. thick. A cup, one inch diameter and 0.125 inch depth, is die pressed for holding the sample. 


\section{PROCEDURS 34 (Cont Id.)}

small beaker facilitates the final transfer to a counting dish.)

3. Evaparate the liquid in the small beglor to dryness.

4. Dissolve the residue in about $1 / 2 \mathrm{ml} I \mathrm{~N} \mathrm{HNO}$. Transfor this liquid to a counting dish using a pipette. liash the walls of the beaker with another $1 / 2$ ml of acid, and add this to the dish.

5. Dry under an in tra-red lamp.

The radianctivity of the sample can be counted in a conventional and window Geiger-kueller counter.

\section{RESULTS}

More detailed studies of the various steps indicated that the average total $108 s e s$ in the colum operation were less than one per cent. Lbout $10^{6} \mathrm{c} / \mathrm{m}$ of $\mathrm{Sr}^{89}$ was used to study the losses. Similar studies with Bello likewise gave losses of about one per cent.

This procedure was also tested for total recovery of $5 x^{89}$ tracer at levels of about $75 \mathrm{c} / \mathrm{m}$. This test was made on urine samples from individuals who had not been exposed to fission product contaunation. To 18 of the samples was added the extra $600 \mathrm{mg}$ calcium; the other 4 had no extra calcium. No difference was noted in the per cent of recovery. In the 22 experimental runs, the recovery averaged $93.7 \% \pm 2.5$ per cent (standard deviation) of sr 89 tracer. The average counting error was about $2.7 \mathrm{c} / \mathrm{m}$ at a $90 \%$ confidence level. In determining the per cent recovery, a volume of $\mathrm{Sr}^{89}$ tracer equal to that put in the urine samples was evaporated in the center of a counting dish and used as a "standard". The "standards" and urinalysis samples were counted at about the same time to avoid errors due to decay of $\mathrm{Sr}^{89}$. Since some of the residue in a urinalysis sample is displaced farther from the center than the "standards", a reduction in efficiency of counting can be expected due to this lateral displacement. The final per cont recovery took into consideration both chemical losses and decreased counting efficiency. 


\section{SEPARATION FBOM $\mathrm{K}^{40}$}

In order to determine the presence of radioactive strontium and barium at very low levels, a urinalysis procedure must provide good separation from $\mathrm{K}^{40}$, a bete emitier that is present in urine. Urine specimens from 17 persons who had not been exposed to flission prochuct contamination, were checked by this procecure. Average radioactivity due to 140 was $0.7 \mathrm{c} / \mathrm{m}$ at about $25 \%$ goometry. The maximam was $1.7 \mathrm{c} / \mathrm{m}$.

\section{SUMMRY}

In the radiochemical analysis of strontium and barium in large volumes of urine, an alkaline earth phosphate precipitation is used to concentrate the strontium and barium. The separation of large amounts of calcium and magnesium from tracer amounts of strontium and barium is done on one ion exchange colum by the use of versene and citric acid as complexing agents. Over-all losses of $\mathrm{sr}^{89}$ on the colum are about one per cent. Urine samples containing from 150 to $800 \mathrm{mg}$ calcium gave equally good recovery. Since no "carriers" are added, this method may be useful for analyzing bone or urine for non-radioactive strontium and barium. This procedure is simple in operation, has a minimum number of steps, and provides excellent recovery of radioactive strontium and barium in human urine.

\section{PROCEDURE 35}

\section{STRONTIUM}

Source - E. A. Martell in "The Chicago Sunshine Method", U. S. Atomic Energy Commission Report AaCU-3262, Page 44, May, 1956.

\section{Strontium Separation Procedure for 5 Grams of bone Ash}

(Method of Dr. John Harley, Health and Safety Laboratory, New York Operations Office, U. S. Atomic Energy Commission)

1. Ash in nickel crucible at $900 \mathrm{C}$. 
2. Grind in wortar to a fine pouder.

3. Weigh out 5 gram into a $250 \mathrm{ml}$ centrifuge bottle.

4. Idd $44 \mathrm{ml}$ of water and then slowly add $154 \mathrm{ml}$ of $90 \%$ nitric acid to bring concentration to $75 \%$.

5. Idd 20 me of strontium carrier as $\mathrm{Sr}\left(\mathrm{NO}_{3}\right)_{2}$ in a 2 al solution.

6. Stir rapidly for 30 mimites (mochanically).

7. Centrifuge for 10 mutes at 2000 r.p.m.

8. Decant and repeat steps 4,5 , and 7 at half the original rolums.

9. Decant as much as possible and trans fer to $100 \mathrm{ml}$ beakar with $\mathrm{H}_{2} \mathrm{O}$.

10. Bvaparate to dryness to expel all the nitric acid.

11. Pick up with $50 \mathrm{ml} \mathrm{H}_{2} \mathrm{O}$; complete solution should result.

12. Heat this solution to boiling. Adjust pH to approximtaly 7 with $\mathrm{NaOH}$. Idd $10 \mathrm{mll}$ of $10 \% \mathrm{Na}_{2} \mathrm{CO}_{3}$, digest with beating until precipitation of $\mathrm{SrCO}_{3}$ is complete.

13. Filter through Tracerlab section filter apparatus and wash with $0.58 \mathrm{Na}_{2} \mathrm{CO}_{3}$. Draw air through the filter for a fer minites to ary out tho precipitate. (Tho $\mathrm{Na}_{2} \mathrm{CO}_{3}$ is dried to constant weight in an oven at $110 \mathrm{C}$ for yleld determination, dissolved in $\mathrm{BCl}$, and reserved for $\mathrm{Y}$ growth and subsequent miliking.)

\section{Notes:}

1. The recovery of strontium this procedure can be mintained at about 95\%. The direct solubility of strontium nitrate in the $75 \%$ nitric acid is about $13 \mathrm{mg}$ of strontium per 21ter. This is very markedly reduced by the presence of calcium nitrate. For this reason, the calcium nitrate is mintained at, at least $50 \%$ of saturation in the firat separation. The solubility of calcium nitrate is equivalent to 23.5 grams of CaO per liter of $75 \%$ nitric acid. 
2. Other types of samples are given a preliminary chemical treatment to bring them to the form calcium oxide plus strontium oxide. The nitrate separation is then carried out as for bone except that the amount of $75 \%$ nitric acid is regulated to take solubility considerations into account.

\section{PROCEDURE 36}

\section{STRONIIIM}

Source - E. 1. Martell in The Chicago Sunshine Method", U. S. Atomic Energy Commission Report $\triangle \mathrm{ECU}-3262$, Page 49, May, 1956.

\section{Strontium Separation from 40 Liters of Seavater}

1. Filter original sample of 40 liters of seawater to remove suspended organic and inorganic material. Since the suspended material is discarded, the filter ma be changed frequently to speed filtration.

2. To filtrated seawater add $\mathrm{SrCl}_{2}$ standard solution containing about 3.5 grams of strontium. Add 400 grams $\mathrm{NH}_{4} \mathrm{Cl}$ as a buffer to hold magnesium in solution. $\Lambda d d \sim 700$ grams $\mathrm{Na}_{2} \mathrm{CO}_{3}$ to precipitate calcium and strontium and allow mixture to settle overnight. Discard bulk of supernate by decantation and filter remainder through whatman th2 paper in large Buchner funnei

3. Dissolve carbonates in $6 \mathrm{~N} \mathrm{HCl}$ and dilute to a volume of 3 litera. Heat nearly to boiling and add solid $\left(\mathrm{NH}_{4}\right)_{2} \mathrm{Sq}_{4}$ to first cloudiness. Add an additional 6 grams of solid $\left(\mathrm{NH}_{4}\right)_{2} \mathrm{SO}_{4}$, digest for 30 minutes on hot plate (on low), filter and wash with distilled water.

4. Transfer $\mathrm{SrSO}_{4}$ precipitate to a clean beaker and add at least $50 \%$ excess of $\left(\mathrm{NH}_{4}\right)_{2} \mathrm{CO}_{3}$ solution. Digest for 20 minutes on low hot plate. Filter and wash $\mathrm{SrCO}_{3}$ precipitate.

5. Dissolve $\mathrm{SrCO}_{3}$ precipitate in minimum acid and proceed with strontium separation, carrying out at least two barium chromate scavenging precipitations before final determination of strontium as carbonate. 


\section{[Note added in proof]}

During the routine use of this mothod for strontium analysis a very small variable positive blas was encountered. Folloring a discussion with FUDGE AND JENKINS of A.E.R.E. Harwell, special attention was directed to the behaviour of cerium.

A high activity run was carried out and following precipitation of strontium carbonato the strontium was precipltated from fuming nitric acid. A small amount of 141 carlum vas identified remaining in solution on analyais by B-absorption curvo. It is belloved that formation of a radiocollotd is the cause of the solution of a small variable proportion of the corium in the sample. The addition of 10 me of cerlum carrier (as cerous nitrate) before column treatment has been proved to prevent elution of the radiocorium, and the bias was remored from the mothod. 


\section{REFERENCES}

1. D. N. Sunderman and W. W. Meinke, reference cited in General Reference Section II.

2. H. H. Willard and E. W. Goodspeed, Ind. Eng. Chem., Anal. Ed., 8, 4 ل 4 (1936).

3. M. L. Salutsky and H. W. Kirby, Anal. Chem. 27, 567 (1955).

4. N. H. Furman, "Scott's Standard Methods of Chemical Analysis", Van Nostrand, New York, 1939.

5. P. J. Elving and R. E. VanAtta, Anal. Chem. 22, 1375 (1950).

6. D. N. Sunderman and $W$. Wayne Meinke, Anal. Chem. 29, 1578 (1957).

7. D. N. Sunderman and W. W. Meinke, Anal. Chem. 29, 1578 (1957).

8. R. Overstreet, L. Jacobson, K. Scott, and J. G. Hamilton, Procedure 26 in Section VII.

9. T. Kurbatov, F. Yu, and J. Kurbatov, J. Chem. Phys. 16, 87 (1948).

10. J. Kurbatov, J. Kulp, and E. Mack, J. Am. Chem. Soc. 67, 1923 (1945).

11. J. Khym, P. Tompkins, and W. Cohn, MDDC-1214 (1947).

12. P. C. Tompkins, L. Wish, and J. X. Khym, Paper 239 in "Radiochemical Studies: The Fission Products", edited by C. Coryell, and N. Sugarman, MaGram-Hill, New York, 1951.

13. T. Schonfield, M. Weld, and M. Brund, Proceedings of the International Conference on the Peaceful Uses of Atomic Energy (1958), Paper No. 1439.

I4. I. E. Glendenin, Procedure 28 in Section VII.

15. J. S. Fritz, R. T. Oliver, and D. J. Pietrzyk, Anal. Chem. 30, 1111 (1958).

16. R. Pribil and D. Marcova, Chem. Listy 45, 542 (1951).

17. F. Feigl and H. A. Suter, Ind. Eng. Chem. Anal. ed. 14, 840 (1942).

18. J. F. Flagg, "Organic Reagents Used in Gravimetric and Volumetric Analysis", Interscience Publishers, Inc., New York, 1948, p. 217.

19. A. Broido, in Procedure 18 in Section VII.

20. A Broido, U. S. Atomic Eñergy Comission Report AECD-2616, July, 1947 .

21. R. A. Bolomey and L. Wish, J. Am. Chem. Society 72, 4483 (1950).

22. A. S. Goldin, U. S. Atomic Energy Comnission Report TID-7517 (Part Ib), p. 323 (1956).

23. W. B. Silker, Hanford Atomic Products Operation Report HW-55117, May, 1958.

24. A. S. Goldin, R. J. Velten and G. W. Frishkorm, Anal. Chem. 31, 1490 (1959).

25. T. Kiba and S. Mizukami, Buil. Chem. Soc. Japan 31, 1007 (1958).

26. G. H. Norrison and H. Freiser, "Solvent Extraction in Analytical Chemistry", John Wiley and Sons, Inc., Nen York, 1957.

27. W. F. Hillebrand, et al., Reference cited in Section I.

28. H. H. Barber, Ind. Eng. Chem,, Anal. Ed. 13, 572 (1947).

29. N. M. Tillu and N. S. Telang, J. Indian Chem. Soc. 19, 231 (1942).

30. D. Dyrssen, Svensk Kem. Tidskr. 67, 311 (1955). 
31. G. H. Morrison and H. Freiser, "Solvent Extraction in Analytical Chemistry", John Wiley and Sons, Inc., Nen York, 1957.

32. D. F. Pepperd, G. W. Kason, and S. W. Moline, J. Inorg. Nuclear Chem. 5, 14 li (1957).

33. O. Bonñer and I. Smith, J. Phys. Chem. 6l, 326 (1957).

34. E. R. Tompkins, J. X. Khym, and W. E. Cohn, J. Am. Chem. Soc. 69, 2769 (1947).

35. E. R. Tompkins, J. Am. Chem. Soc. 70, 3520 (1948).

36. H. H. Power, H. T. Kirby, H. C. McCluggage, G. D. Nelson, and J. H. Payne, Jr., Anal. Chem. 31, 1077 (1959).

37. E. A. Martell, Procecture 29 in Section VII.

38. C. W. Stanley and P. Kruger, Nucleonics 14, No. 11, 174 (1956).

39. P. Kruger and C. D. Coryell, J. Chem. Educ. 32, 280 (1955).

40. L. B. Farabee, Arch. Ind. Health 17, 200 (1958).

4l. G. W. Milton and W. E. Grumitt, Gan. J. Chem. 35, 541 (1957).

42. P. S. Davis, Nature 183, 674 (1959).

43. M. J. Cabell, AERE-C7I, Dec. 29, 1954.

44. M. Lerner and W. Rieman III, Anal. Chem. 26, 610 (1954).

45. H. L. Finston and J. Kiskel, Ann. Rev. Nuclear Sci. 5,274 (1955).

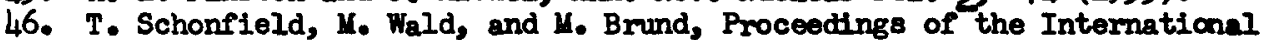
Conference on the Peacerul Uses of Atomic Energy, Geneve (1958), Paper No. 1439.

47. R. W. Perkins, Anal. Chem. 29, 152 (1957).

48. F. Nelson and K. Krause, J. Am. Chem. Soc. 77, 801 (1955).

49. R. H. James and G. A. Welch, Nature 177, 183 (1956).

50. J. C. Delton and G. A. Welch, Anal. ChIm. Acte. 15, 317 (1956).

51. F. P. Treadrell and W. T. Hall, reference cited in General Reference Section I.

52. B. Kahn, Oak Ridge National Laboratory Report ORNI-1951, October 14, 1955 .

53. B. Kahn, Anal. Chem. 28, 216 (1956).

54. E. A. Martell, U. S. Atomic Energy Comission Report ADCU-3262, May, 1956.

55. W. F. Merritt, Can. J. Chem. 36, 425 (1958).

56. A. S. Goldin, R. J. Velten, and G. W. Frishkorn, Anal. Chem. 31, 1490 (1959).

57. D. Strominger, J. M. Hollander, and O. T. Seaborg, Rerrs. Yodern Phys. 30, 585 (1958).

58. B. P. Bayhurst, in Procedure 18 in Section VII.

59. A. S. Goldin, U. S. Atomic Energy Comission Report, TID-7517 (Part 1b), P. 323 (1956).

60. E. A. Martell, U. S. Atomic Bnergy Comission Report ABCU-3262, May 1956.

61. E. A. Bryant, J. E. Sattizahn, and B. Warren, Anal. Chem. 31, 334. (1959).

62. L. E. GIendenin in Procedure 13 in Section VII.

63. L. B. Farabee, Oak Ridge National Laboratory Report, ORWL1932, P. 12 (1955).

64. D. F. Peppard, G. W. Mason, and S. W. Moline, J. Inorg. Nuclear Chem. 5, 141 (1957).

65. 0. Hahn and F. Stressmann, Naturwissenschaften, 27: 11 (1939).

66. I. E. Glendenin, Report CC-971, Sept, 15, 1943.

67. A. Seidell, "Solubilities of Inorganic and Metal Organic Compounds," Vol. I, p. 158, D. Van Nostrand Company, Inc., New York, 1940.

68. W. Rubinson, Report CC-1142, Dec. 13, 1943.

69. C. M. Nelson, W. F. Boldridge, and D. N. Hume, Report CN-2570, February 1945.

70. B. Finkle and N. Sugarman, Paper 166 in "Radiochemical Studies: The Fission Products", edited by C. D. Coryell and N. Sugarman, McGraw-Hill, New York, 1951.

71. E. GIueckauf and P. J. P. Roberts, A.E.R.E., C/R I 443. 
72. R. H. James and G. A. Welch, Nature, 177 (1956) 183.

73. L. E. Glendenin, Radiochemical Studies: The Fission Products, Nat. Nucl. En. Series, IV, 9, VI, MoGraw-Hill Book Co., Inc., New York 1951, Paper 236, pp. 1460-64 and Paper 283, pp. 1642-45.

74. R. B. Hahn and B. O. Backer, Report A.E.C.U.-2903, April 1955.

75. A. A. Noyes and W. C. Bray, A System of Quantitative Analysis for the Rare Elements, Mackillan Co., New York, 1927.

76. J. M. Hollander, I. Perlman and G. T. Seaborg, Rev. Mod. Phys. 25 (1953) 469.

77. Hanson, W. C., Private Communication.

78. Martell, E. A., Chicago Sunshine Method: Absolute Assay of Strontium-90 in Biological Materials, Soils, Waters, and Air Filters, AECU-3262, Hay 1956.

79. Glendenin, L. E., Paper 236 (Coryell and Sugarman, Radiochemical Studies: The Fission Products, McGraw-Hill Book Co.e Inc., New York, 1951) National Nuclear Energy Series, Plutonium Project Record, Vol. 9, Div. IV.

80. Perkins, R. W., To be published.

81. C. Lieber, Naturwissenschaften, 27: 421 (1939).

82. W. H. Sullivan, Report CC-765, June 30, 1943.

83. L. E. Glendenin, Report CC-971, September 15, 1943.

84. D. N. Hume, Clinton Iaboratories Weekly Report, January 21, 1944.

85. L. E. Glendenin, Paper 288 in "Radiochemical Studies: The Fission Products", edited by C. D. CoryellI and N. Sugarman, McGram-Hill, New York, 1951.

86. E. H. Swift, "A System of Chemical Analysis", p. 376, Prentice-Hall, Inc., New York, 1938.

87. C. Lieber, Naturwissenschaften, 27: 421 (1939).

88. L. E. Glendenin, Paper 236 in "Radiochemical Studies: The Fission Products", edited by C. D. Coryell and N. Sugarman, MoGraw-Hill, New York, 1951.

89. A Seideli, "Solubilities of Inorganic and Metal Organic Compounds", 3d ed., D. Van Nostrand Company, Inc., New York, 1940.

90. J. G. Hamilton, Report $\mathrm{CH}-957, \mathrm{~S}_{\mathrm{ept}}$. 25, 1943. 


\title{
NUCLEAR SCIENCE SERIES: MONOGRAPHS ON RADIOCHEMISTRY, RADIOCHEMICAL TECHNIQUES, AND NUCLEAR MEDICINE
}

\author{
Aveilable from the National Technical Information Service, \\ U. S. Department of Commerce, Springfield, Virginia 22161
}

\section{ELEMENTS}

Aluminum and Gallum, NAS-NS-3032 [1961]. $\$ 925$

Amencium and Curium. NAS-NS-3006 [1960]. $\$ 975$

Antumony, NAS-NS-3033 [1961], $\$ 950$

Arsenic. NAS-NS-3002 (Rev) [1965], \$9 25

Astatine, NAS-NS-3012 [1960], $\$ 900$

Banum, Calcium, and Strontium, NAS-NS-

3010 [1960], $\$ 1100$

Beryllum, NAS-NS-3013 [1960], $\$ 950$

Bismuth, NAS-NS-3061 [1977], \$11 75

Cadmum, NAS-NS-3001 [1960], \$9 50

Carbon, Nitrogen, and Oxygen, NAS-NS3019 [1960], $\$ 875$

Cestum, NAS-NS-3035 [1961], \$975

Chromum, NAS-NS-3007 (Rev) [1964], $\$ 975$

Cobalt. NAS-NS-3041 [1961], $\$ 1050$

Copper, NAS-NS-3027 [1961], \$9 50

Fluonne. Chlonne, Bromine, and lodine. NAS-NS-3005 [1960], $\$ 925$

Francium, NAS-NS-3003 [1960], $\$ 900$

Germanium, NAS-NS-3043 [1961], $\$ 925$

Gold, NAS-NS-3036 [1961], $\$ 900$

Indium, NAS-NS-3014 [1960], \$9 25

lodine, NAS-NS-3062 [1977], $\$ 1075$

Indium, NAS-NS-3045 [1961], $\$ 900$

Iron, NAS-NS-3017 [1960], \$925

Lead, NAS-NS-3040 [1961], $\$ 1200$

Magnesum, NAS-NS-3024 [1961]. \$8 75

Manganese. NAS-NS-3018 (Rev) [1971]. $\$ 975$

Mercury. NAS-NS-3026 (Rev) [1970], \$13 25

Molybdenum, NAS-NS-3009 [1960], $\$ 900$

Neptunum, NAS-NS-3060 [1974], \$1375

Nickel, NAS-NS-3051 [1961], $\$ 950$

Niobium and Tantalum, NAS-NS-3039 [1961]. $\$ 950$

Osmium, NAS-NS-3046 [1961], \$8 75

Palladium, NAS-NS-3052 [1961], $\$ 975$

Phosphorus, NAS-NS-3056 [1962], $\$ 900$

Platinum, NAS-NS-3044 [1961], $\$ 900$

Plutonium, NAS-NS-3058 [1965], \$12 75

Polonium, NAS-NS-3037 [1961], $\$ 975$

Potassium, NAS-NS-3048 [1961], \$9 25

Protactinuum, NAS-NS-3016 [1959], $\$ 1025$

Radium, NAS-NS-3057 [1964], \$13 25

Rare Earths-Scandlum, Yttnum, and Actınum, NAS-NS-3020 [1961], \$15 25

Rare Gases, NAS-NS-3025 [1960], $\$ 950$

Recent Radiochemical Separation Procedures

for As, At, Be, Mg. Ni, Ru, and Se, NAS-NS3059 [ 1974], \$10 25

Rhenium. NAS-NS-3028 [1961], $\$ 925$

Rhodium, NAS-NS-3008 (Rev) [1965], \$10 00

Rubidium, NAS-NS-3053 [1962], $\$ 900$

Ruthenium, NAS-NS-3029 [1961], $\$ 1025$

Selentum, NAS-NS-3030 (Rev) [1965], $\$ 50$

Silicon, NAS-NS-3049 (Rev) [ 1968], $\$ 1000$

Sitver, NAS-NS-3047 [19611, $\$ 950$

Sodium, NAS-NS-3055 [1962], \$925

Sulfur, NAS-NS-3054 [1962], $\$ 900$

Technetuum, NAS-NS-3021 [1960], $\$ 950$
Tellunum, NAS-NS-3038 [1961], \$925

Thonum, NAS-NS-3004 [1960], $\$ 1000$

Tin. NAS-NS-3023 [1960], $\$ 1000$

Titanum, NAS-NS-3034 (Rev) [1971], $\$ 1050$

Transcurlum Elements. NAS-NS-3031 [1960]. $\$ 900$

Tungsten, NAS-NS-3042 [1961], \$925

Uranium, NAS-NS-3050 [1961], $\$ 1700$

Vanadium, NAS-NS-3022 [1960], $\$ 1000$

Zinc. NAS-NS-3015 [1960], \$950

Zirconum and Hafnuum, NAS-NS-3011 [1960]. $\$ 950$

\section{TECHNIQUES}

Absolute Measurement of Alpha Emission and Spontaneous Fission, NAS-NS-3112 [1968], \$950

Activation Analysis with Charged Particles, NAS-NS-3110 [1966], $\$ 925$

Application of Distillation Techniques to Radiochemical Separations. NAS-NS-3108 [1962], \$900

Applications of Computers to Nuclear and Radrochemistry, NAS-NS-3107 [1962], \$16 00

Cation-Exchange Techniques in Radıchemistry. NAS-NS-3113 [1971]. $\$ 1300$

Chemical Yield Determinations in Radiochemistry, NAS-NS-3111 [1967], \$10 50

Detection and Measurement of Nuclear Radiation, NAS-NS-3105 [1962], \$1175

Liquid-Liquid Extraction with High-

Molecular-Weight Amines, NAS-NS-3101 [1960], \$1025

Low-Level Radiochemical Separations. NAS-NS-3103 [1961], $\$ 900$

Neutron Activation Techniques for the Measurement of Trace Metals in Environmental Samples, NAS-NS-3114 [1974], $\$ 1000$

Paper Chromatographic and Electromigration Techniques in Radiochemistry, NAS-NS3106 [1962], $\$ 925$

Processing of Countung Data, NAS-NS-3109 [1966], \$12 25

Rapid Radiochemical Separations. NAS-NS3104 [1961], \$1125

Separations by Solvent Extraction with Tri-r-octylphosphine Oxide. NAS-NS-3102 [1961], $\$ 950$

Users' Gundes for Radioactivity Standards. NAS-NS-3115 [1974], \$1025

\section{NUCLEAR MEDICINE}

The Synthesis of Carbon-11, Fluonne-18, and Nitrogen-13 Labeled Radiotracers for Bromedical Apphications, NASNS-3201 [1982], \$11 25

Radionucilde Generators for Bromedical Applications, NAS-NS-3202/JAA, R D Finn, $V$ J Molinsk!. H B Hupf, and H Kramer (1983), \$12 25 